\title{
Assessment of the environmental impact of yeast waste application to soil: an integrated approach
}

\author{
Ricardo Manuel Reis da Mata
}

Dissertation to obtain a master's degree in

Environmental Engineering

Supervisor: Dr. David Paulo Fangueiro

Jury:

President: Dr. Elizabeth da Costa Neves Fernandes de Almeida Duarte, Professora Catedrática do Instituto Superior de Agronomia da Universidade de Lisboa

Examinators: Dr. David Paulo Fangueiro, Professor Auxiliar do Instituto Superior de Agronomia da Universidade de Lisboa

Dr. Rita do Amaral Fragoso, Professora Auxiliar do Instituto Superior de Agronomia da Universidade de Lisboa 
The intersection of Science and Art creates world wonders

Ricardo Reis 
The yeast production industry (e.g. distillery, brewing, baking industries) has been growing globally over the last years generating a large amount of sub-products. Laboratory experiments, under controlled conditions, were performed to investigate the impact of yeast waste application to a sandy texture soil. Experimental treatments were: surface application of yeast and decanted-yeast (CMSs and CMSds), surface application of yeast and decantedyeast followed by incorporation in the $0-5 \mathrm{~cm}$ soil layer (CMSm and CMSdm), surface application of ammonium nitrate (AN) (not applied in short-term experiment) and a control (soil only) (CTR). The amount of yeast applied was $2 \mathrm{~g}$ in the short-term experiment and equivalent to $170 \mathrm{kgN} \mathrm{ha}^{-1}$ in the long-term experiment. A short-term (38-day period) leaching experiment was performed with 5 weekly irrigation events ( 5 treatments $\times 3$ replications) to assess $N, P$, $\mathrm{K}$ losses. Results showed that yeast application increased $\mathrm{NH}_{4}{ }^{+}, \mathrm{P}_{\mathrm{T}}$ and $\mathrm{K}_{\mathrm{T}}$ leaching relative to control while decreased $\mathrm{NO}_{3}{ }^{-}$leaching relative to a high initial content of control, during first irrigation events. Incorporation treatments increased $\mathrm{NH}_{4}{ }^{+}, \mathrm{NO}_{3}{ }^{-}$and $\mathrm{P}_{\mathrm{T}}$ losses earlier. $\mathrm{K}_{\mathrm{T}}$ losses were higher in surface treatments. A long-term leaching experiment (73-day period) with 6 irrigation events every two weeks was then performed ( 6 treatments $\times 4$ replicates) to assess $\mathrm{N}, \mathrm{P}$ losses. A two parallel incubation experiment ( 6 treatments $\times 3$ replicates) were simultaneously performed to measure $\mathrm{GHG}$ emissions $\left(\mathrm{CO}_{2}, \mathrm{~N}_{2} \mathrm{O}, \mathrm{CH}_{4}\right)$ and to assess the $\mathrm{N}$ mineralization in each treatment. Results showed that yeast application increased initial $\mathrm{NH}_{4}{ }^{+}$ concentration in leachates and soil relative to control and $\mathrm{NO}_{3}{ }^{-}$increased afterwards. $\mathrm{N}_{2} \mathrm{O}$ and $\mathrm{CO}_{2}$ increased significantly relative to control on the first days after yeast application. AN treatment emissions were very similar to control but had a small increase of $\mathrm{N}_{2} \mathrm{O} . \mathrm{CH}_{4}$ emissions were insignificant. The global warming potential (GWP) of yeast and AN were $6 \times$ and $2 \times$ times higher than control, respectively.

Keywords: yeast, soil, groundwater, pollution, greenhouse gases 
Resumo

A indústria de produção da levedura (ex. indústrias de distilaria, cervejeira, panificação) tem vindo a aumentar globalmente nos últimos anos generando grandes quantidades de subprodutos. Experiências laboratorais, sob condições controladas, foram realizadas para investigar o impacte da aplicação do resíduo de leveduras num solo arenoso. Os tratamentos experimentais foram: A aplicação à superfície da levedura e levedura-decantada (CMSs e CMSds), a aplicação à superfície da levedura e levedura-decantada seguida da incorporação na camada 0-5 cm (CMSm e CMSdm), a aplicação à superfície de $\mathrm{NH}_{4} \mathrm{NO}_{3}(\mathrm{AN})$ (não aplicado na lixiviação curta-duração) e o controlo (CTR) sem aplicação. A quantidade de levedura aplicada foi $2 \mathrm{~g}$ (experiência de curta-duração) e $170 \mathrm{kgN}$.ha-1 (experiência de longa-duração). Uma lixiviação de curta-duração (durante 38 dias) com 5 eventos de irrigação semanalmente foi realizada (5 tratamentos $\times 3$ réplicas) para avaliar as perdas de $N, P, K$. Os resultados demonstraram que a aplicação da levedura aumentou a lixiviação de $\mathrm{NH}_{4}{ }^{+}, \mathrm{P}_{\mathrm{T}}$ e $\mathrm{K}_{\mathrm{T}}$ relativamente ao controlo enquanto o $\mathrm{NO}_{3}$ - desceu relativamente à elevada quantidade inicial no controlo, durante os primeiros eventos de irrigação. Os tratamentos com incorporação aumentaram prematuramente as perdas de $\mathrm{NH}_{4}{ }^{+}, \mathrm{NO}_{3}{ }^{-}$e $\mathrm{P}_{\mathrm{T}}$. Os tratamentos à superfície aumentara as perdas de $\mathrm{K}_{\mathrm{T}}$. Uma lixiviação de longa-duração (durante 73 dias) com 6 eventos de irrigação de duas em duas semanas (6 tratamentos $\times 4$ réplicas) para avaliar as perdas de $N$, P. Uma experiência paralela de incubação (6 tratamentos $\times 3$ réplicas) foi simultaneamente feita para medir os GEE emitidos $\left(\mathrm{CO}_{2}, \mathrm{~N}_{2} \mathrm{O}, \mathrm{CH}_{4}\right)$. Outra incubação (6 tratamentos $\times 3$ réplicas) foi realizada para avaliar a mineralização do azoto em cada tratamento. Os resultados demonstraram que a aplicação da levedura aumentou inicialmente a concentração de $\mathrm{NH}_{4}{ }^{+}$nos lixiviados e no solo relativamente ao controlo e o $\mathrm{NO}_{3}{ }^{-}$aumentou seguidamente. $\mathrm{N}_{2} \mathrm{O}$ e $\mathrm{CO}_{2}$ aumentaram significativamente relativamente ao controlo nos primeiros dias depois da aplicação da levedura. As emissões no tratamento AN foram semelhantes ao controlo, com um ligeiro aumento de $\mathrm{N}_{2} \mathrm{O}$. As emissões de $\mathrm{CH}_{4}$ foram insignificantes. O Potencial de aquecimento global (PAG) obtido com aplicação de levedura e com AN foram, respectivamente, $6 \times$ e $2 \times$ vezes maiores do que o valor registado no control.

Palavras-chave: levedura, solo, águas subterrâneas, poluição, gases com efeito de estufa 
Resumo alargado

A Terra é um planeta dinâmico coberto com ar, água e solo sustentáveis à vida que estão em constante interação energética e material. A qualidade ambiental depende da gestão de resíduos como fonte de nutrientes para o solo, progredindo as suas propriedades físicas, químicas e biológicas. O impacte da gestão de nutrientes é mais direccionado para a qualidade da água devido à infiltração de poluentes (nitratos e fósforo) para as águas subterrâneas mas também para o compartimento atmosférico devido à emissão de gases com efeito de estufa.

A área Mediterrânea é caracterizada como tendo um solo degradado, exposto a grandes variações climáticas, um conteúdo pobre em $\mathrm{P}, \mathrm{N}$ e matéria orgânica, principalmente na camada superficial, e consequentemente erodido. O uso intensivo de fertilizantes minerais na prática agrícola é responsável pela degradação ambiental bem como pelo decréscimo da MO e efeitos nefastos no crescimento das culturas.

Os resíduos orgânicos com elevado conteúdo orgânico são uma excelente fonte de nutrientes, particularmente $\mathrm{K}$ e $\mathrm{N}$, e devem ser aplicados como correctivo orgânico, reduzindo a sua eliminação por aterro e assegurando o reciclo de nutrientes e a fertilidade do solo. No entanto, existe uma preocupação relativo ao impacte ambiental associado à aplicação deste tipo de resíduos caso estes contenham um elevado teor orgânico e baixo $\mathrm{pH}$. Algumas substâncias não desejadas podem ser encontradas, como metais pesados e patogénicos, levando a um impacte negativo na qualidade dos produtos agrícolas, biodiversidade e saúde humana. Como o teor de $\mathrm{N}$ pode ser alto, na maior na forma orgânica e consequentemente indisponível para as plantas, a sua aplicação em grandes proporções leva à contaminação das águas subterrâneas por nutrientes não absorvidos.

$\mathrm{O} \mathrm{NO}_{3}{ }^{-}$é altamente movél no solo devido à sua fraca interacção com a carga negativa da matrix. De acordo com a Directiva dos Nitratos (91/676/CEE), as águas subterrâneas são consideradas poluídas se os níveis de nitrato atingirem valores de $50 \mathrm{mg} \cdot \mathrm{L}^{-1}$. As concentrações de $\mathrm{NH}_{4}{ }^{+}$na solução do solo normalmente são pequenas devido à sua alta retenção mas podem aumentar em solos com textura arenosa e fraca capacidade de retenção catiónica.

A preocupação das perdas de $\mathrm{P}$ por lixiviação nos solos arenosos tem vindo a aumentar, principalmente nos habitats marinhos, devido à eutrofização de sistemas de água doce, promovendo o crescimento de algas e plantas marinhas. No entanto, as perdas de P são neglegenciadas devido à sua elevada capacidade de retenção mesmo após grandes inputs 
de água. A dinâmica do $\mathrm{P}$ depende altamente dos valores de $\mathrm{pH}$. Para níveis baixos de $\mathrm{pH}, \mathrm{o}$ fosfato pode ser adsorvido pelos óxidos de ferro (Fe) e alumínio ( $\mathrm{Al}$ ), partículas com capacidade de troca aniónica. Em solos alcalinos, este tende a formar compostos com Ca.

O K é altamente móvel nos solos e consequentemente quantidades significativas podem ser perdidas por lixiviação. A suas perdas são frequentemente um problema em solos arenosos devido ao baixo conteúdo em argila e fraca interacção com a matriz e dependem maioritariamente da CTC, textura e pH do solo e concentrações de $\mathrm{Ca}^{2+}$. Uma baixa lixiviação de potássio pode ser observada em níveis de pH entre 6 e 6.5, devido à sua substituição por $\mathrm{Ca}^{2+}$ pela competição nas águas lixiviadas.

Os GEE através das actividades humanas são os maiores condutores da alteração climática observada nos meados do século 20. $\mathrm{CO}_{2}, \mathrm{~N}_{2} \mathrm{O}$ e $\mathrm{CH}_{4}$ são os três principais GEE que contribuem para a alteração dos ecossistemas e aquecimento global, e a maioria das emissões são geradas pelo sector agro-pecuário devido ao uso de fertilizantes sintécticos e processos biológicos. De facto, os processos biológicos neste sector e noutras fontes (ex. gás de pântano) são os maiores responsáveis pelo elevado aumento dos níveis globais de metano na atmosfera. A prática agrícola é responsável por 1:3 dos GEE e a alteração climática provavelmente irá causar descidas dos rendimentos. Sob condições aeróbias, o $\mathrm{N}_{2} \mathrm{O}$ é relevante nas actividades agrícolas devido à aplicação de residuos com alto teor de $\mathrm{N}$ que pode dar origem à formação de nitrato dependendo das condições ambientais.

O resíduo de levedura é obtido pelo processamento e separação da levedura do mosto, rico em proteínas, carbohidratos, vitaminas e alguns minerais, gerado durante a fermentação alcoólica. O melaço da beterraba ou cana é a principal matéria-prima usada para fornecer o açucar necessário para o desenvolvimento das células da levedura. Estudos anteriores concluíram que a aplicação da levedura no solo pode ser uma grande fonte de nutrientes para o crescimento das plantas, levando a uma mineralização dos compostos orgânicos. No entanto, devido ao seu alto conteúdo orgânico e carbono lábil, a levedura pode estimular a produção de $\mathrm{CO}_{2}$ e o aumento de nitrato e fósforo lixiviado. A CE também pode ser alta em alguns resíduos de levedura e o seu uso indiscrimado pode afectar as propriedades físicoquímicas do solo, como o aumento da pressão osmótica, consequentemente perdas de água, e toxicidade do solo.

O principal objectivo deste estudo é avaliar o impacte da aplicação de dois resíduos de levedura (CMS e CMSdecantado) a um solo ácido e arenoso, seguindo a lixiviação potencial de nutrientes nas águas subterrâneas em dois ensaios independentes (curta e longa duração), a mineralização do azoto no solo e a emissão de GEE na atmosfera num ensaio de incubação laboratorial. 
A amostra de solo foi recolhida em Palmela, Portugal, numa parcela de solo agrícola não fertilizada há mais de 10 anos. A amostra de solo utilizada para a experiência de lixiviação curta-duração foi armazenada e considerada perturbada. Os tratamentos experimentais foram: A aplicação à superfície do CMS e CMSd, a aplicação à superfície do CMS e CMSd com posterior incorporação na camada $0-5 \mathrm{~cm}$, a aplicação à superfície AN (não aplicado na lixiviação curta-duração) e o controlo (CTR) sem aplicação. A quantidade de levedura aplicada foi $2 \mathrm{~g}$ (experiência de curta-duração) e $170 \mathrm{kgN} \mathrm{ha}^{-1}$ (experiência de longa-duração). $\mathrm{O}$ programa estatístico utilizado foi o Statistix, de modo a estudar a variância entre tratamentos (ANOVA 1-factor), temporal (ANOVA 2-factores) e o erro padrão (teste de Tukey) num intervalo de confianção a 5\%. No ensaio de lixiviação curta-duração (durante 38 dias), 15 tubos de PVC foram montados ( 5 tratamentos $\times 3$ réplicas) para avaliar as perdas de $\mathrm{N}, \mathrm{P}, \mathrm{K}$, durante 5 eventos de irrigação com $300 \mathrm{~mL}$ de água desionizada 3 dias após a aplicação. Os resultados demostraram que a aplicação da levedura aumentou a lixiviação de $\mathrm{NH}_{4}{ }^{+}, \mathrm{P}_{\mathrm{T}}$ e $\mathrm{K}_{\mathrm{T}}$ enquanto que $\mathrm{O} \mathrm{NO}_{3}{ }^{-}$desceu relativamente à elevada quantidade inicial no controlo, nas primeiras irrigações. Os tratamentos com mistura aumentaram prematuramente as perdas de $\mathrm{NH}_{4}{ }^{+}, \mathrm{NO}_{3}{ }^{-}$e $\mathrm{P}_{\mathrm{T}}$. Os tratamentos sem incorporação aumentaram as perdas de $\mathrm{K}_{\mathrm{T}}$. No ensaio de lixiviação longa-duração (durante 73 dias), 24 tubos de PVC foram montados (6 tratamentos $\times 4$ réplicas) para avaliar as perdas de $N$, $P$, e foram feitos 6 eventos de irrigação em cada duas semanas com $300 \mathrm{~mL}$ de água desionizada 3 dias após a aplicação. Neste ensaio usaram-se colunas de solo não perturbado. Um ensaio de incubação (6 tratamentos $\times$ 3 réplicas) foi realizado para medir as emissões de $\mathrm{GEE}\left(\mathrm{CO}_{2}, \mathrm{~N}_{2} \mathrm{O}, \mathrm{CH}_{4}\right)$. Durante 78 dias foram feitas 21 medições. Os gases $\mathrm{N}_{2} \mathrm{O}$ e $\mathrm{CO}_{2}$ aumentaram significativamente nos primeiros dias depois da aplicação da levedura. As emissões no tratamento com AN foram semelhantes ao controlo mas com um ligeiro aumento de $\mathrm{N}_{2} \mathrm{O}$. As emissões de $\mathrm{CH}_{4}$ foram insignificantes. O Potencial de Aquecimento Global observado com aplicação de levedura e do nitrato de amónio foram, respectivamente, $6 \times$ e $2 \times$ vezes maiores que o valor observado no control. Outro ensaio de incubação ( 6 tratamentos $\times 3$ réplicas) foi realizado durante 77 dias para avaliar a mineralização do azoto no solo. Os resultados demonstraram que a aplicação da levedura aumentou inicialmente o $\mathrm{NH}_{4}{ }^{+}$lixiviado e no solo relativamente ao controlo e o $\mathrm{NO}_{3}{ }^{-}$ aumentou depois disso. $\mathrm{O} \mathrm{P}_{\mathrm{T}}$ lixiviado foi semelhante em todos os tratamentos. Para solos saturados ou períodos de irrigação intensos, o tratamento com incorporação aumentou a emissão de GEE e a lixiviação de P. Por outro lado, uma frequência menor de irrigação leva à diminuição da desnitrificação, permitindo um maior conteúdo de nitratos relativamente aos tratamentos à superfície. No ensaio de longa-duração, os valores de $\mathrm{NO}_{3}{ }^{-}$lixiviado (2a irrigação) foram maiores que o valor máximo admissível $50 \mathrm{mg} \cdot \mathrm{L}^{-1}$. As emissões de $\mathrm{N}_{2} \mathrm{O}$ dependeram do tipo de resíduo, no qual a levedura não decantada teve maiores valores. Em ambos os resíduos houve um aumento da mineralização dos compostos orgânicos, para a 
captação da planta, e do pH no solo. A aplicação de $\mathrm{NH}_{4} \mathrm{NO}_{3}$, relativamente às leveduras, aumentou significativamente a lixiviação de nitratos, e a sua aplicação mesmo em pequenas quantidades pode facilmente poluir os cursos de água. Por outro lado, as emissões de GEE foram muito baixas. Neste estudo observou-se um balanço entre o tipo de fonte de nutrientes (levedura ou $\mathrm{NH}_{4} \mathrm{NO}_{3}$ ) e o tipo de compartimento poluído (atmosférico ou águas subterrâneas). Acredita-se que a aplicação mais segura em solos arenosos e ácidos, seja a aplicação à superfície da levedura decantada, levando a uma maior retenção de amónio no solo acrescentado às menores emissões cumulativas de $\mathrm{N}_{2} \mathrm{O}$ entre os dois tipos de resíduo e, em condições de chuva não intensa, perdas de $\mathrm{NO}_{3}$. 
Index

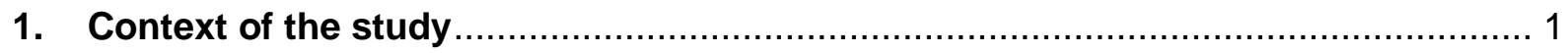

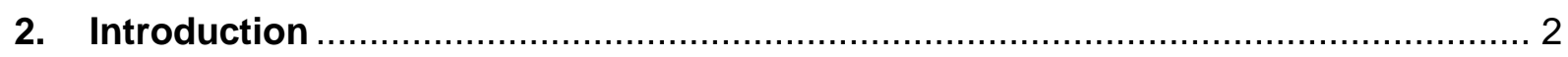

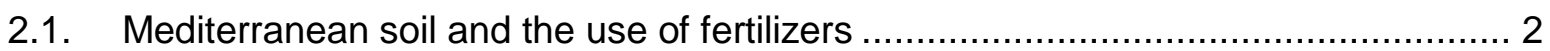

2.2. Organic wastes, benefits and consequences ................................................. 2

2.3. Nutrients leaching and water quality ..................................................... 4

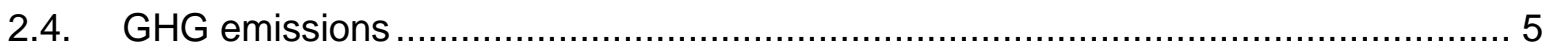

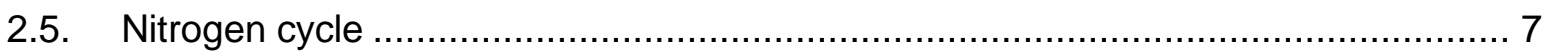

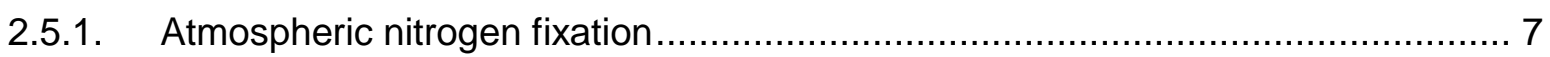

2.5.2. Nitrogen mineralization ......................................................................... 8

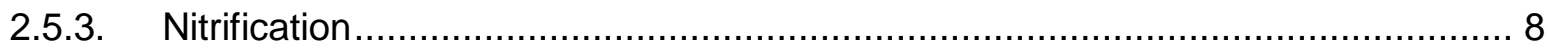

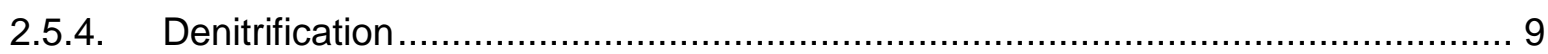

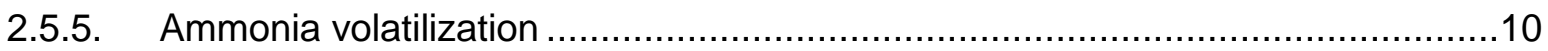

2.5.6. Anammox (anaerobic ammonia oxidation) …............................................ 10

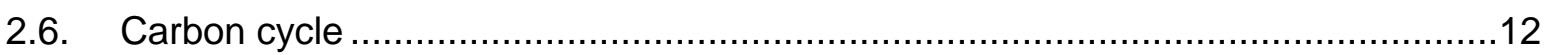

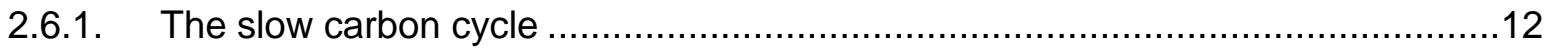

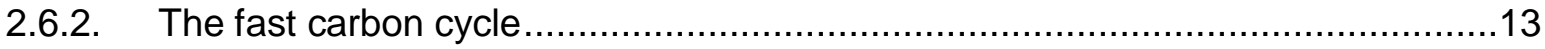

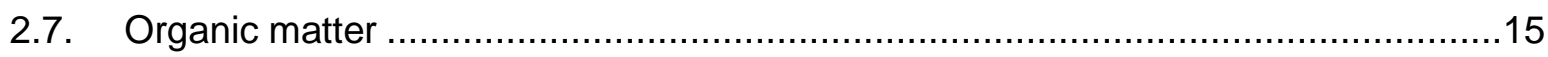

2.8. Decomposition and mineralization of organic compounds ................................16

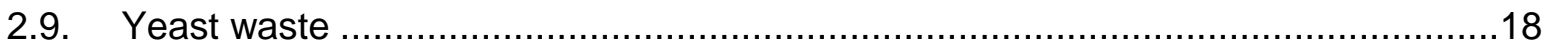

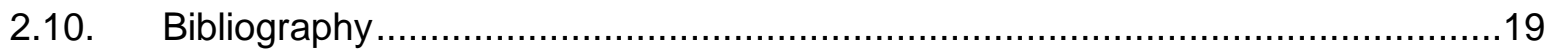

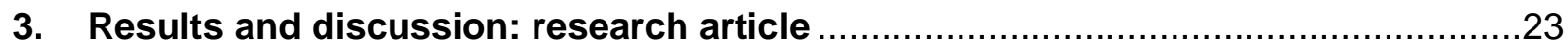

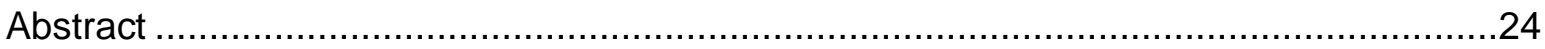

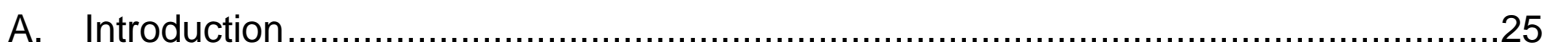

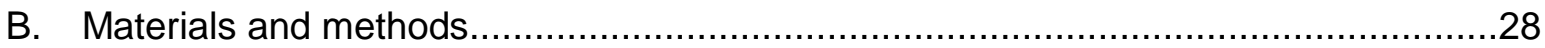

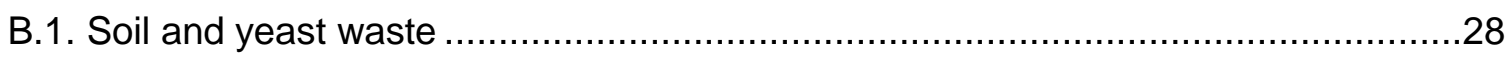

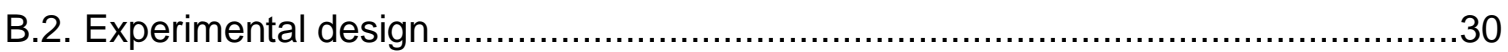

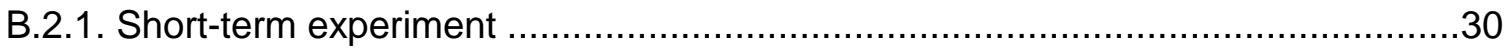


B.2.2. Long-term experiment

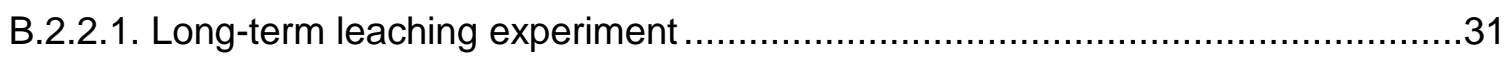

B.2.2.2. GHG emissions and Nitrogen mineralization experiment...............................32

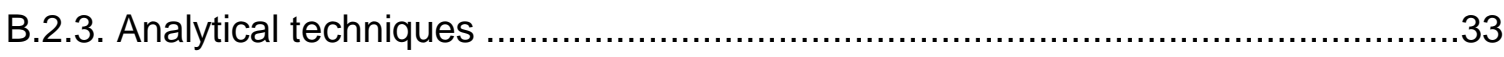

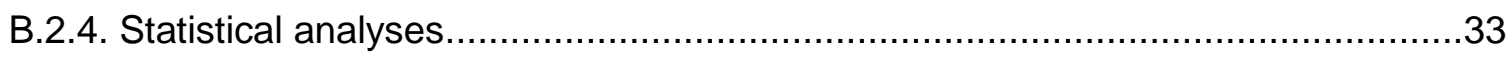

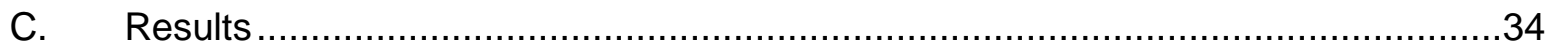

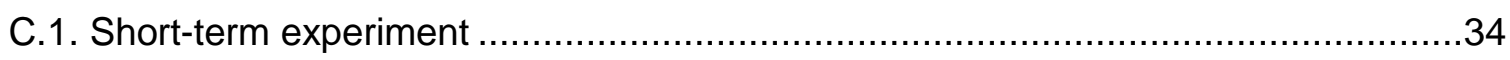

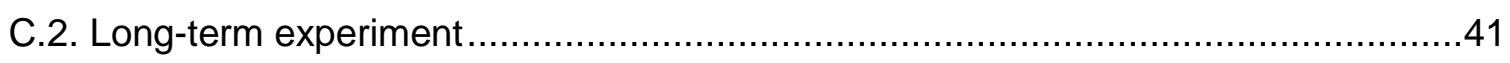

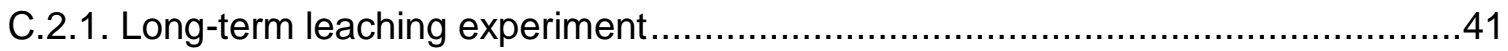

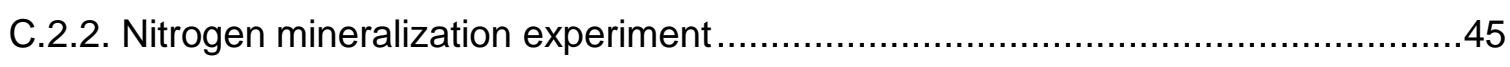

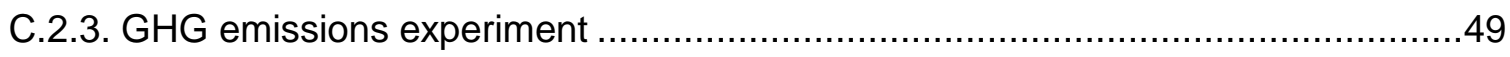

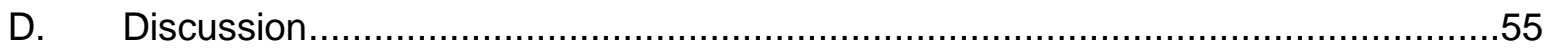

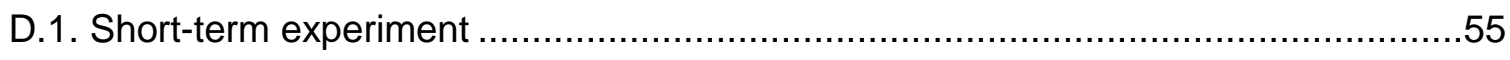

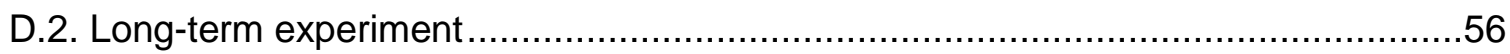

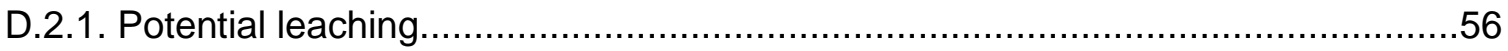

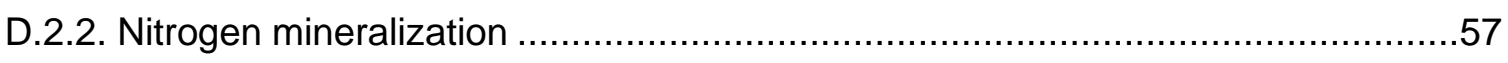

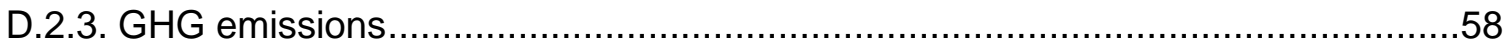

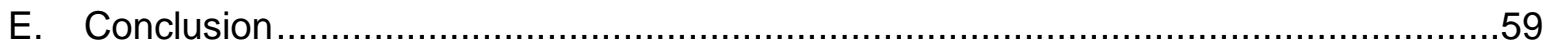

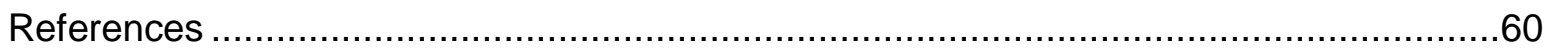


Figures index

Figure 1 - Effects of increasing soil organic matter content and overall soil fertility by soil carbon improvement (Diacono and Montemurro, 2010).

Figure 2 - Hydrological cycle - groundwater and surface water relationships along with and groundwater pollution risks (UNEP, 2001)

Figure 3 - Carbon dioxide levels in the atmosphere (NASA, 2016) ................................. 6

Figure 4 - Greenhouse gas emissions from agriculture activity (FAO, 2016).

Figure 5 - Model of the relationship between water-filled pore space of soils and the relative fluxes of nitrogen gases from nitrification. (Bouwman, 1998) .......................................... 9

Figure 6 - Nitrogen cycle (Bernhard, 2010)

Figure 7 - The processing and fluxes of reactive nitrogen in terrestrial and marine systems and in the atmosphere $\left(\mathrm{Tg}_{\mathrm{yr}} \mathrm{H}^{-1}\right)$, showing the dominant forms of the reactive $\mathrm{N}$ in the exchanges and the magnitude of the boundary fluxes, and approximate lifetimes, integrated over global scales (Fowler et al., 2013).

Figure 8 - Fast carbon cycle (Bot and Benites, 2005). .14

Figure 9 - Carbon cycling and biosequestration (U.S. DOE, 2008). 14

Figure 10 - Topsoil organic carbon in Europe (Jones et al., 2004).

Figure $\mathrm{A} 1$ - $\mathrm{pH}$ of leachates observed during the 5 irrigation events performed in the short-term experiment (38-day period). Means of 6 replicates. Error bars represent the standard error used on each leaching event to assess significant $(P<0.05)$ differences between mean values.

Figure A2 - EC of leachates observed during the 5 irrigation events performed in the shortterm experiment (38-day period). Means of 6 replicates. Error bars represent the standard error used on each leaching event to assess significant $(P<0.05)$ differences between mean values.

Figure A3 - Ammonium concentration of leachates observed during the 5 irrigation events performed in the short-term experiment (38-day period). Means of 6 replicates. Error bars represent the standard error used on each leaching event to assess significant $(P<0.05)$ differences between mean values.

Figure A4 - Nitrate concentration of leachates observed during the 5 irrigation events performed in the short-term experiment (38-day period). Means of 6 replicates. Error bars represent the standard error used on each leaching event to assess significant $(P<0.05)$ differences between mean values. .36

Figure A5 - Phosphorus concentration of leachates observed during the 5 irrigation events performed in the short-term experiment (38-day period). Means of 6 replicates. Error bars 
represent the standard error used on each leaching event to assess significant $(P<0.05)$ differences between mean values.

Figure A6 - Potassium concentration of leachates observed during the 5 irrigation events performed in the short-term experiment (38-day period). Means of 6 replicates. Error bars represent the standard error used on each leaching event to assess significant $(P<0.05)$ differences between mean values.

Figure $\mathrm{A} 7$ - Variation of the $\mathrm{pH}$ along the soil columns at the end of the short-term experiment. Means of 3 replicates. Error bars represent the standard error used on each leaching event to assess significant $(P<0.05)$ differences between mean values. .38 Figure A8 - Variation of the EC along the soil columns at the end of the short-term experiment. Means of 3 replicates. Error bars represent the standard error used on each leaching event to assess significant $(P<0.05)$ differences between mean values.

Figure A9 - Variation of the ammonium content along the soil column at the end of the shortterm experiment. Means of 3 replicates. Error bars represent the standard error used on each leaching event to assess significant $(P<0.05)$ differences between mean values. .39 Figure A10 - Variation of the nitrate content along the soil column at the end of the short-term experiment. Means of 3 replicates. Error bars represent the standard error used on each leaching event to assess significant $(P<0.05)$ differences between mean values.

Figure $\mathrm{A} 11-\mathrm{pH}$ of leachates observed during the 6 irrigation events performed in the longterm experiment (73-day period). Means of 4 replicates. Error bars represent the standard error used on each leaching event to assess significant $(P<0.05)$ differences between mean values.

Figure A12 - EC of leachates observed during the 6 irrigation events performed in the longterm experiment (73-day period). Means of 4 replicates. Error bars represent the standard error used on each leaching event to assess significant $(P<0.05)$ differences between mean values.

Figure A13 - Ammonium concentration of leachates observed during the 6 irrigation events performed in the long-term experiment (73-day period). Means of 4 replicates. Error bars represent the standard error used on each leaching event to assess significant $(P<0.05)$ differences between mean values.

Figure A14 - Nitrate concentration of leachates observed during the 6 irrigation events performed in the long-term leaching (73-day period). Means of 4 replicates. Error bars represent the standard error used on each leaching event to assess significant $(P<0.05)$ differences between mean values.

Figure A15 - Phosphorus concentration of leachates observed during the 6 irrigation events performed in the long-term leaching (73-day period). Means of 4 replicates. Error bars 
represent the standard error used on each leaching event to assess significant $(P<0.05)$ differences between mean values.

Figure A16 - Evolution of soil pH during the long-term experiment (77-day period). Means of 3 replicates. Error bars represent the standard error used on each leaching event to assess significant $(\mathrm{P}<0.05)$ differences between mean values.

Figure A17 - Evolution of soil EC during the long-term experiment (77-day period). Means of 3 replicates. Error bars represent the standard error used on each leaching event to assess significant $(P<0.05)$ differences between mean values.

Figure A18 - Evolution of soil ammonium content during the long-term experiment (77-day period). Means of 3 replicates. Error bars represent the standard error used on each leaching event to assess significant $(P<0.05)$ differences between mean values.

Figure A19 - Evolution of soil nitrate content during the long-term experiment (77-day period). Means of 3 replicates. Error bars represent the standard error used on each leaching event to assess significant $(P<0.05)$ differences between mean values.

Figure A20- Evolution of soil Net nitrogen mineralization during the long-term experiment (77day period)

Figure A21 - $\mathrm{N}_{2} \mathrm{O}-\mathrm{N}$ emissions evolution during the long-term experiment (78-day period). Means of 3 replicates. Error bars represent the standard error used on each leaching event to assess significant $(P<0.05)$ differences between mean values.

Figure $\mathrm{A} 22-\mathrm{N}_{2} \mathrm{O}-\mathrm{N}$ emissions evolution during the long-term experiment (78-day period). Means of 3 replicates.

Figure A23 - Cumulative $\mathrm{N}_{2} \mathrm{O}-\mathrm{N}$ emissions during the long-term experiment (78-day period).

Figure A24 - $\mathrm{CO}_{2}-\mathrm{C}$ emissions evolution during the long-term experiment (78-day period). Means of 3 replicates. Error bars represent the standard error used on each leaching event to assess significant $(P<0.05)$ differences between mean values.

Figure $\mathrm{A} 25-\mathrm{CO}_{2}-\mathrm{C}$ emissions evolution during the long-term experiment (78-day period). Means of 3 replicates.

Figure A26 - Cumulative $\mathrm{CO}_{2}-\mathrm{C}$ emissions during the long-term experiment (78-day period).

Figure A27 - $\mathrm{CH}_{4}-\mathrm{C}$ emissions evolution during the long-term experiment (78-day period). Means of 3 replicates. Error bars represent the standard error used on each leaching event to assess significant $(P<0.05)$ differences between mean values.

Figure A28 - Global Warming Potential based on a 100-year time frame of GHG emissions during incubation experiment (78-day period) .54 
Table index

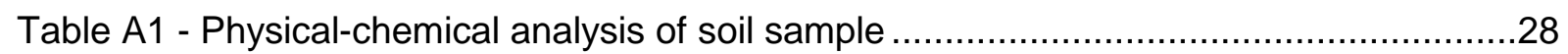

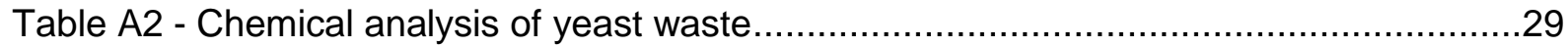


List of abbreviations, acronyms and chemical symbols

C - Carbon

CEC - Cation-exchange capacity

$\mathrm{CH}_{4}$ - Methane

CMS - Yeast waste

CMSd - Decanted yeast waste

$\mathrm{CO}_{2}$ - Carbon dioxide

EC - electrical conductivity

FAO - Food and Agriculture Organization

GHG - Greenhouse gas

IPCC - Intergovernmental Panel on Climate Change

K - Potassium

$\mathrm{N}$ - Nitrogen

NASA - National Aeronautics and Space Administration

$\mathrm{NH}_{4} \mathrm{NO}_{3}(\mathrm{AN})$ - Ammonium nitrate

$\mathrm{NH}_{4}^{+}$- Ammonium

$\mathrm{NO}_{3}{ }^{-}-$Nitrate

$\mathrm{N}_{2} \mathrm{O}$ - Nitrous oxide

OC - Organic carbon

OM - Organic matter

P - Phosphorus

UNEP - United Nations Environment Programme

WFPS - Water-filled pore space

WWF - World Wildlife Fund 


\section{Context of the study}

The yeast production industry (e.g. distillery, brewing, baking industries) has been growing globally over the last years and large amounts of yeast waste are produced during alcohol fermentation. In order to respect the quality of our environment that has suffered significant alterations along this century, the idea of the environmental sustainability has been a pathway for such industries. The reuse of generated wastes, particularly in agronomic and energetic sectors, minimizing the waste disposal is one step to decrease the anthropogenic pollution.

In the present study, two independent experiments were performed, a short-term experiment where strong irrigation events were applied to soil columns amended with yeast waste, decanted yeast waste and ammonium nitrate, simulating an intensive rainfall. A long-term experiment was then performed with moderate irrigation events to assess potential leaching in a similar soil column experiment. Nitrogen mineralization in soil and greenhouse gases emissions were also assessed in an aerobic incubation, in order to assess the potential impact of yeast waste application to agricultural soils in two main environmental compartments, groundwater and atmosphere. The study will be presented as an article research, preceded by an introduction in which the main scientific concepts and the problematic about organic wastes application to soil are exposed. 


\section{Introduction}

\subsection{Mediterranean soil and the use of fertilizers}

Soil is a dynamic ecosystem that supplies naturally organic matter and minerals for plants nutrition (Bot and Benites, 2005). However, its degradability is increasing at global level leading to a negative impact on living organisms and natural resources. Indeed, a new study reported that humans, probably, erode soil 100x faster than nature (lacurci, 2015). The Mediterranean area is typically characterized as having a degraded soil exposed to fires and violent precipitation events by dries summers and excessive winter rains (Larchevêque et al., 2006; Yaalon, 1997), dramatically changing agriculture systems predictions. Furthermore, $\mathrm{P}, \mathrm{N}$ and organic matter content are low, particularly in topsoil, leading to a disaggregation of soil particles and consequently erosion (Diacono and Montemurro, 2010). The intensive use of mineral fertilizers in agriculture practice is not only responsible for the environmental degradation but also by the decrease of organic matter and delirious effects on crop growth, such as weed competition and product's quality loss. However, negative impacts associated with the use of mineral fertilizers are often suppressed due their importance for the increase of yields and food security. Ammonium nitrogen is a great nitrogen source with a high solubility that considerable changes chemical properties of soil and supplies immediately available nitrogen for plant uptake. Soil acidification, soil humus depletion and greenhouse emissions are often linked after the application of AN in agriculture (Kotschi, 2015).

\subsection{Organic wastes, benefits and consequences}

Organic wastes with high organic content are an excellent potential source of plant nutrients in agricultural soils, particularly potassium and nitrogen, which may be applied as a nutrients supplier/corrective organic thereby reducing landfill disposal and ensuring the recycling of nutrients by the increase of microbial biomass (Alvarenga et al., 2015; Rezende et al., 2004). Furthermore, they are essential for the recovery or replacement of degraded soil fertility, providing organic matter enough to improve physical (soil structure, energy exchange), chemical (nutrients regularization) and biological (energetic and nutritive support) properties (Figure 1).

On the other hand, the defective implementation of organic wastes, particularly with high organic content and low $\mathrm{pH}$, can lead to the concern about the environmental pollution (Pita et 
al., 2010). Undesired substances, such as heavy metals and pathogens, will lead to a greater negative impact on the quality of products, biodiversity and human health (Alvarenga et al., 2015). Sometimes nutrients, including the total nitrogen content, can be high in some of these wastes (Li et al., 1997), mostly organic and consequently unavailable to plants, its application at high rates may lead to contamination of water courses by nutrients not absorbed by plants.

The optimization of organic wastes management is crucial in order to keep fluxes balance, maximizing benefits in agriculture practice to the lower environmental risk (gaseous emissions plus superficial, runoff and leaching of nutrients into water courses) according to the type of soil. Sandy soils, with low humus content and $\mathrm{pH}$, rely heavily on organic matter in order to increase their cation-exchange and water holding capacities and thereafter reducing nutrients losses and increasing their availability for plants.

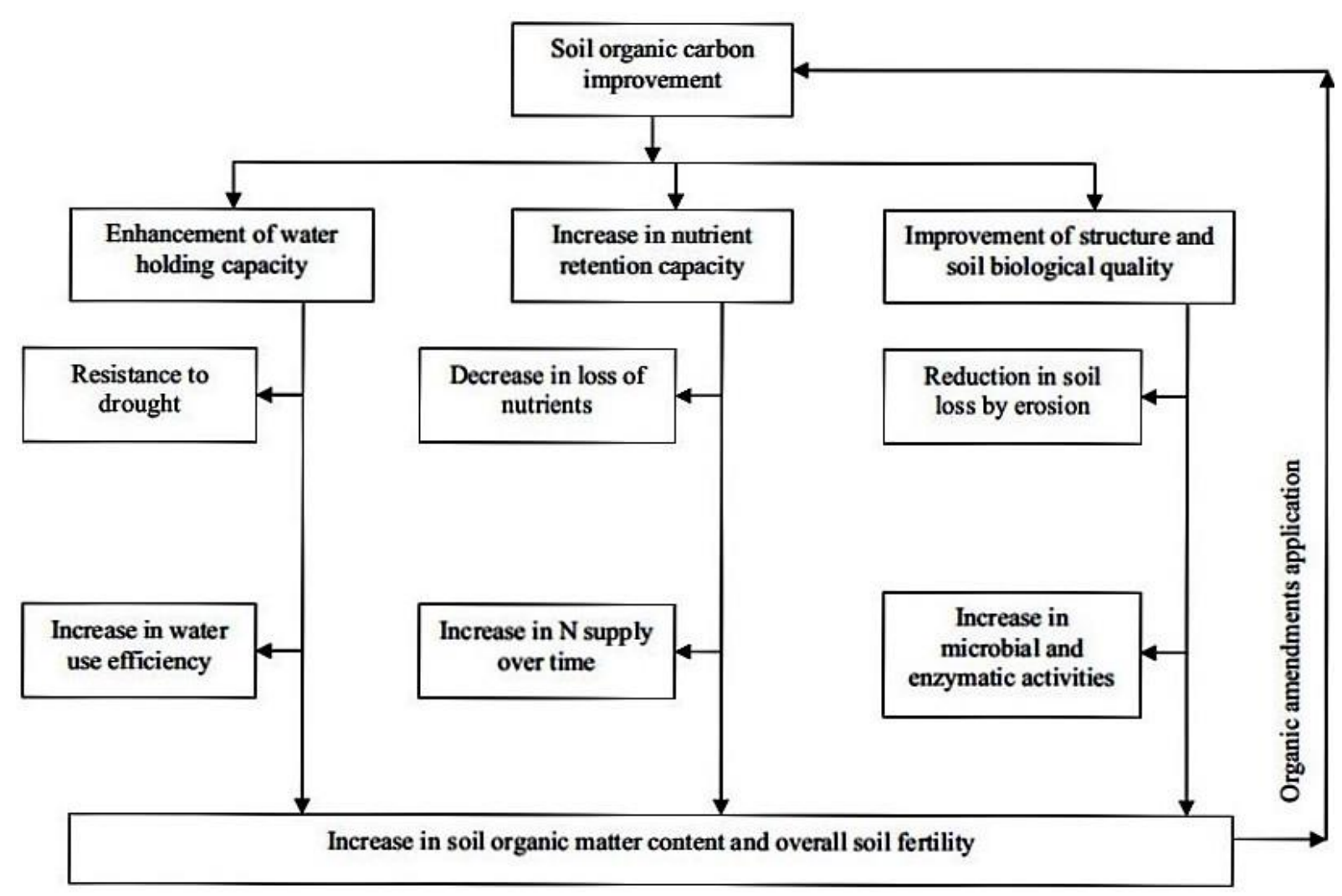

Figure 1 - Effects of increasing soil organic matter content and overall soil fertility by soil carbon improvement (Diacono and Montemurro, 2010). 


\subsection{Nutrients leaching and water quality}

Nutrients leaching from the soil are highly dependent on the rainfall or irrigation events, therefore field capacity, and the permeability of the soil (Loehr, 1974; Lehmann and Schroth, 2003) and may lead to a groundwater contamination (Figure 2).

The majority concern about $\mathrm{N}$ applied in agriculture soils are the leaching of nitrate ions and the surface runoff of organic nitrogen. $\mathrm{NO}_{3}{ }^{-}$is highly mobile in soil due its insignificant interaction to the negative charged matrix. On the contrary, ammonium concentrations in soil solution normally are very low due its high retention but can increase in soils with a sandy texture and low cation-exchange capacity (Fangueiro et al., 2014). Nitrogen fertilizers, such as $\mathrm{AN}$, are the major source of nitrate pollution since they provide immediately $\mathrm{N}$ mineral forms in soil. In fact, Portugal showed a strongest decline in groundwater nitrate concentrations.

Phosphorus losses by leaching have been neglected because their insignificant quantities (Fortune et al., 2005) due its high adsorption in the matrix soil even with a large amount of water input. Furthermore, phosphorus dynamics depend highly on $\mathrm{pH}$ levels. At low $\mathrm{pH}$ levels, phosphate can be adsorbed by iron ( $\mathrm{Fe}$ ) and aluminium ( $\mathrm{Al}$ ) oxides (particles with anion exchange capacity). On the other hand, in alkaline soils it tend to form compounds with Calcium (Ca). However, as arable soils have low clay content, its leaching is a concern, particularly in marine habitats, contributing to eutrophication of freshwater systems (Djodjic and Bergstrom, 2005) thereafter promoting algae and aquatic weed growth. One of the largest sources of $P$ losses is the use of fertilizers in agricultural systems.

Potassium is a mobile ion in soils and consequently significant amounts can be lost by leaching, especially on sandy soils (low clay content) and poor retention. Losses of $\mathrm{K}^{+}$depends mainly on the CEC, soil texture, $\mathrm{pH}$ and Calcium concentrations $\left(\mathrm{Ca}^{2+}\right)$. Normally, a low $\mathrm{K}$ leached is observed at $\mathrm{pH}$ levels between 6-6.5 (Sparks, 2001) due to enhanced substitution of $\mathrm{K}$ for $\mathrm{Ca}$ by its competition in the leaching water and the amount of water that passes through the soil. Indeed, Kolahchi and Jalali (2007) described that high concentrations of cations such as $\mathrm{Ca}^{2+}$ on irrigation waters increase potassium leached. 


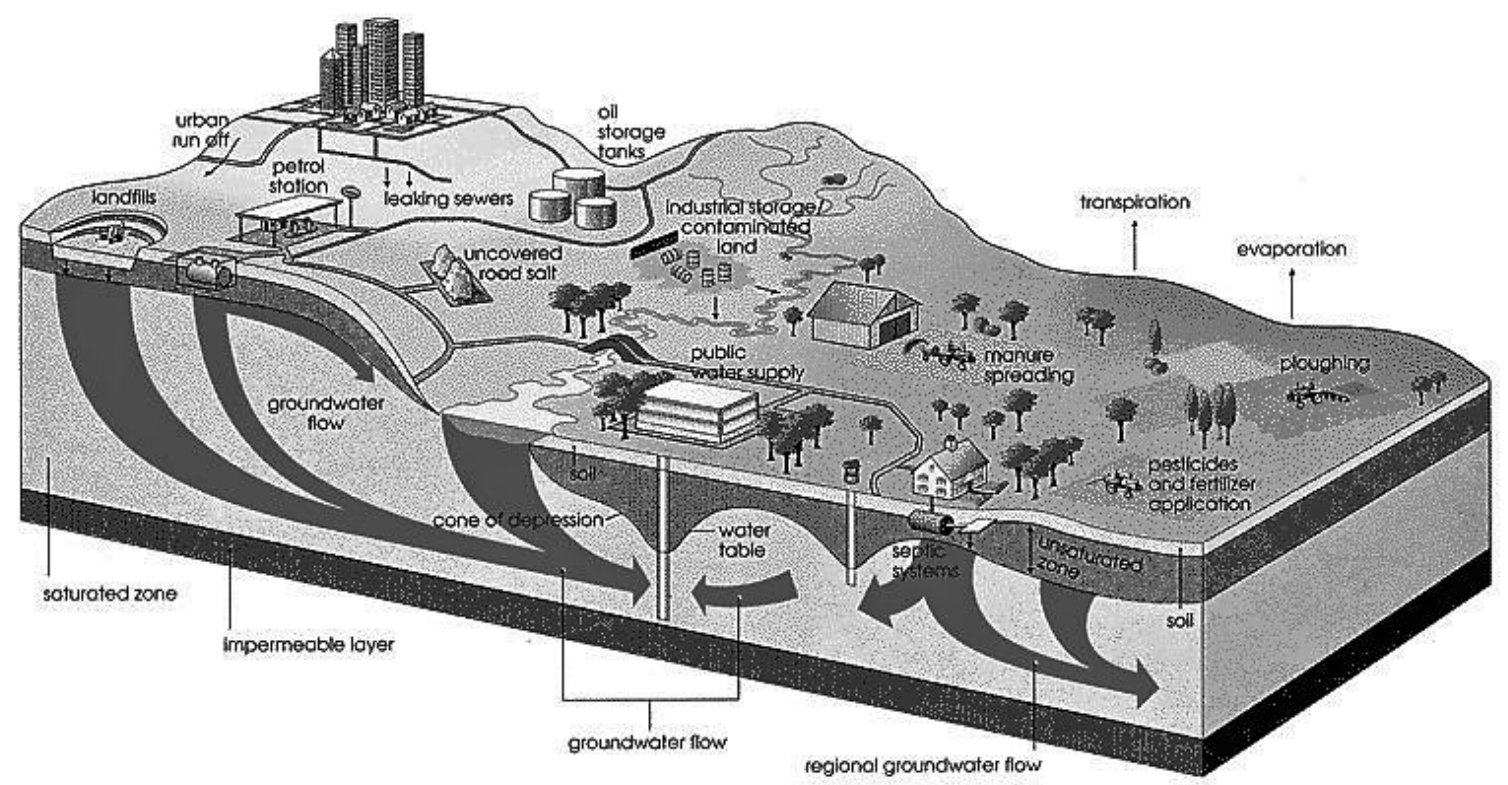

Figure 2 - Hydrological cycle - groundwater and surface water relationships along with and groundwater pollution risks (UNEP, 2001)

\section{4. $\mathrm{GHG}$ emissions}

Greenhouse gases emissions from human activities are the most significant driver of observed climate change since the mid-20th century (IPCC, 2013). Gaseous emissions such as carbon dioxide, nitrous oxide and methane are the three of the main greenhouse gases (GHGs) contributing to ecosystems change and global warming (Fangueiro et al., 2012). At moment, current $\mathrm{CO}_{2}$ levels on atmosphere are approximately 400 ppm (NASA, 2016) (Figure 3), and most of GHG emissions comes from the agropecuary sector due the use of synthetic fertilizers and biological processes (FAO, 2016) (Figure 4). 


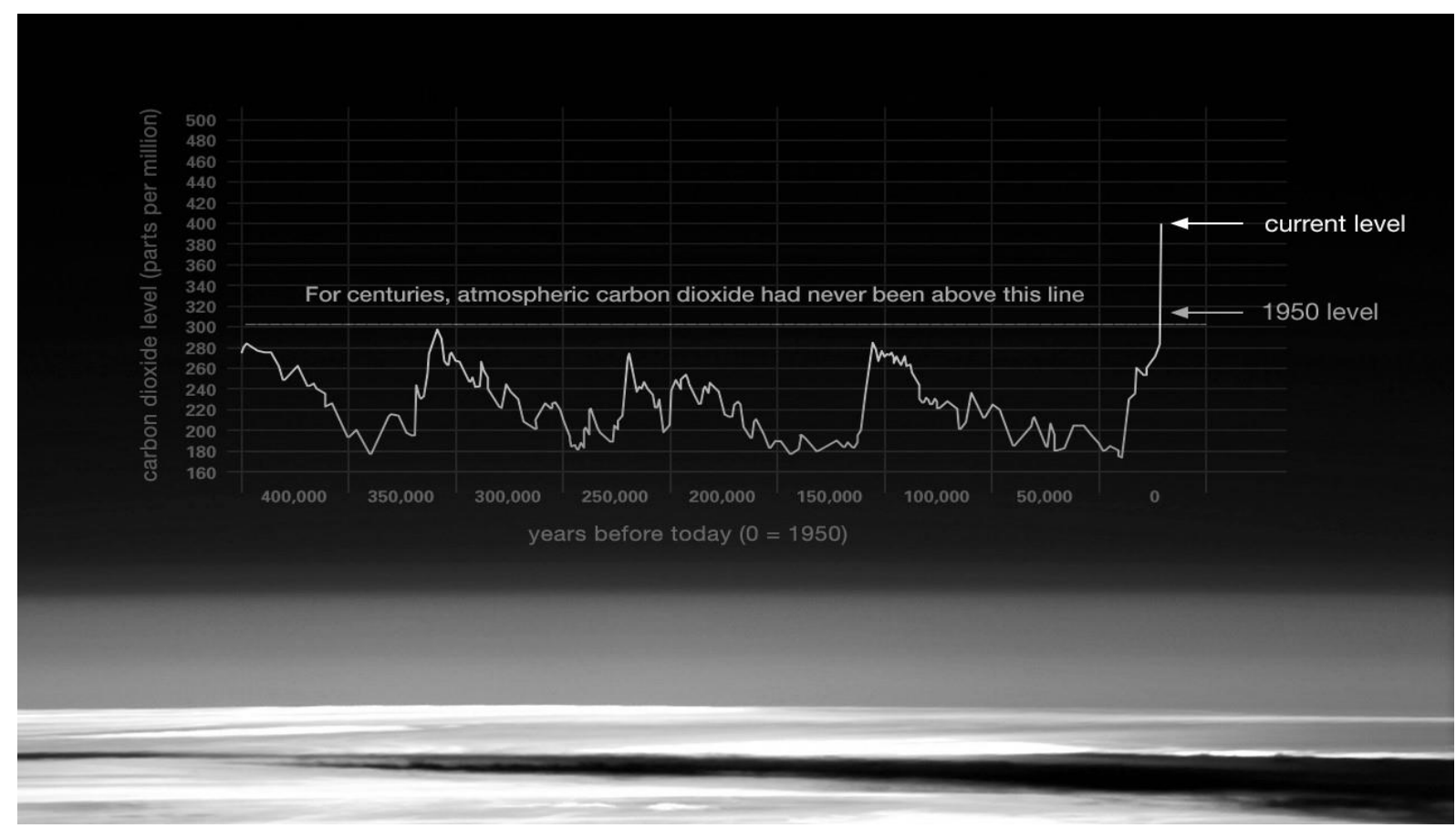

Figure 3 - Carbon dioxide levels in the atmosphere (NASA, 2016).

Indeed, biological processes from this sector and other sources (e.g. swamp gas) are the largest responsible for the strongly increase of global methane levels in atmosphere, especially in hot wet tropic areas. Furthermore, waste disposal increases methane emissions released from the organic matter decomposition in landfills (UNEP, 2001) and Landfill Gas-to-Energy projects are another attractive final destination. Gilbert (2012) published an article referring that agriculture practice, including food systems, is responsible for about one-third of GHG emissions, and climate change probably will cause yields drop. Under aerobic conditions, $\mathrm{N}_{2} \mathrm{O}$ gets special attention in agricultural activities due the application of wastes with high nitrogen content and soil physical-chemical properties and environmental conditions. In fact, in this century, soil will absorb less carbon dioxide from atmosphere than expected and waiting for an uncertain or prolonged carbon sequestration cannot be an option. Depending on future emissions of GHG and how the climate responds, average global temperatures probably can increase by $0.5^{\circ} \mathrm{F}$ to $8.6^{\circ} \mathrm{F}$ by 2100 (IPCC, 2013). 


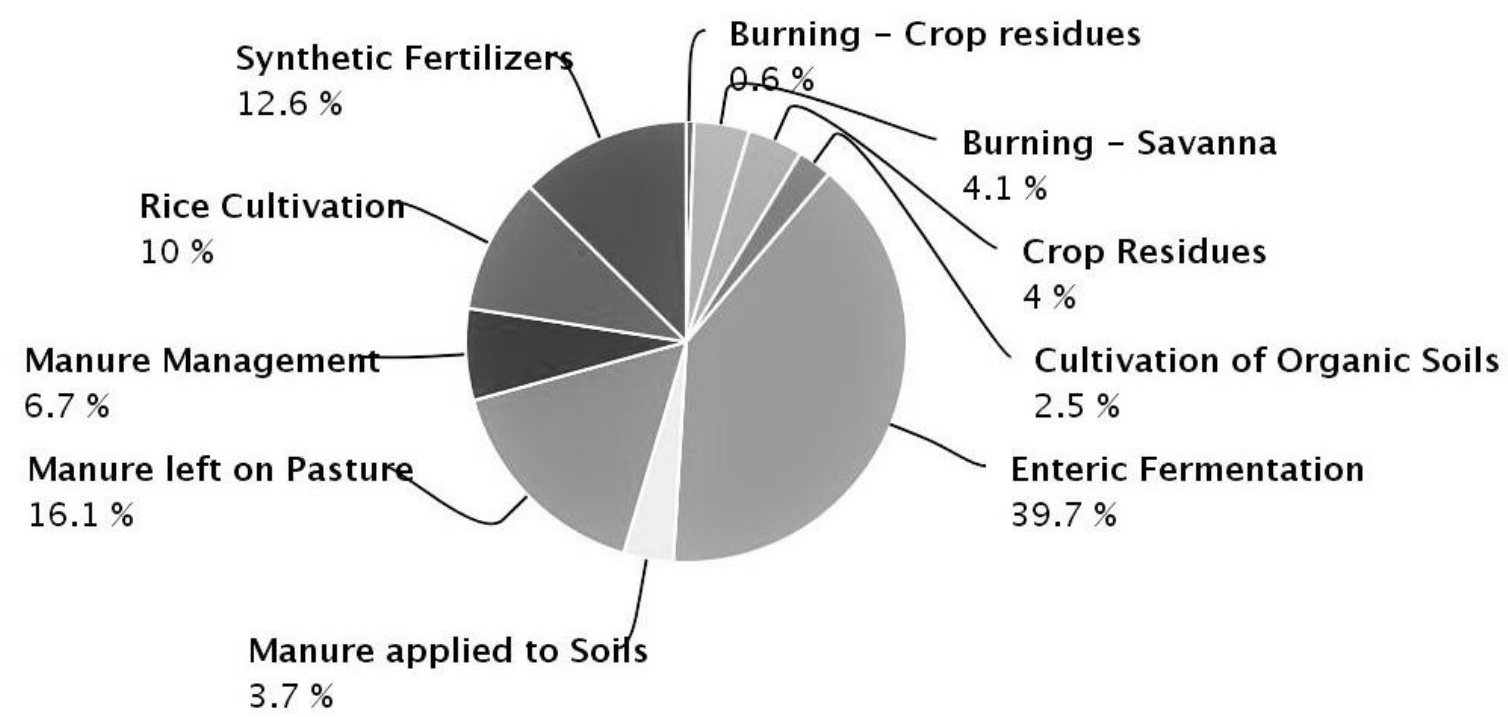

Figure 4 - Greenhouse gas emissions from agriculture activity (FAO, 2016).

\subsection{Nitrogen cycle}

Ammonium $\left(\mathrm{NH}_{4}{ }^{+}\right)$and nitrate $\left(\mathrm{NO}_{3}{ }^{-}\right)$are the mainly inorganic forms available for plants. The anthropogenic addiction of mineral nitrogen in soils can alter the natural interaction between ecosystems leading to various environmental impacts on water courses, carbon sequestration, etc. The organic nitrogen is an organic fraction of organic matter in soils, originated naturally by living organisms or applied by human activities (e.g. wastes discharge) (Figure 7). In fact, according to Bernhard (2010) the amount of nitrogen fixed by human activities probably will exceed that fixed by microbial processes in 2030.

\subsubsection{Atmospheric nitrogen fixation}

Dinitrogen gas $\left(\mathrm{N}_{2}\right)$ is the largest nitrogen form in Earth and is the final stable form of all nitrogen compounds. Atmospheric nitrogen fixation is the process of converting biologically (or industrially) dinitrogen into ammonium (or ammonia) mainly by living organisms (or nonbiological materials e.g. industrial activities, lightning) and a large amount of energy is required to break down $\mathrm{N}$ bonds.

$$
3\left(\mathrm{CH}_{2} \mathrm{O}\right)+2 \mathrm{~N}_{2}+3 \mathrm{H}_{2} \mathrm{O}+4 \mathrm{H}^{+} \rightarrow 3 \mathrm{CO}_{2}+4 \mathrm{NH}_{4}^{+}
$$


or

$$
\mathrm{N}_{2}+8 \mathrm{H}^{+}+8 e^{-} \rightarrow 2 \mathrm{NH}_{3}+\mathrm{H}_{2}
$$

2.5.2. Nitrogen mineralization

Mineralization is the conversion of organic to inorganic nitrogen forms. The first step is aminization, the breakdown of complex nitrogen molecules (e.g. proteins) to simple organic forms $\left(\mathrm{R}-\mathrm{NH}_{2}\right)$ by primarily heterotrophs microorganisms.

$$
\mathrm{N} \text { complex comp. } \rightarrow \mathrm{R}-\mathrm{NH}_{2}+\mathrm{CO}_{2}+\text { energy }+ \text { byproducts }
$$

Ammonification is the final step of mineralization realized by primarily autotrophic microorganisms, in which simple organic forms are converted to ammonia.

$$
\mathrm{R}-\mathrm{NH}_{2}+\mathrm{H}_{2} \mathrm{O} \rightleftharpoons \mathrm{NH}_{3}+\mathrm{R}-\mathrm{OH}+\text { energy }
$$

and (if reacted with water)

$$
\mathrm{NH}_{3(a q)}+\mathrm{H}_{2} \mathrm{O} \rightarrow \mathrm{NH}_{4}^{+}+\mathrm{OH}^{-}
$$

\subsubsection{Nitrification}

Nitrification has two steps and different pathways: The first step is the oxidation of ammonium (or ammonia, via the intermediate hydroxylamine) into nitrite by aerobic ammonia oxidizers (e.g. nitrosomonas) followed by a possible oxidation of nitrite to nitrate through nitrite oxidizing bacteria (e.g. Nitrobacter). Nitrification depends mainly on $\mathrm{pH}$, temperature, aeration and moisture.

$$
2 \mathrm{NH}_{4}^{+}+3 \mathrm{O}_{2} \rightarrow 2 \mathrm{NO}_{2}^{-}+4 \mathrm{H}^{+}+2 \mathrm{H}_{2} \mathrm{O}
$$

and

$$
2 \mathrm{NO}_{2}^{-}+\mathrm{O}_{2} \rightarrow 2 \mathrm{NO}_{3}^{-}
$$

or 


$$
\begin{gathered}
\mathrm{NH}_{3}+\mathrm{O}_{2}+2 e^{-} \rightarrow \mathrm{NH}_{2} \mathrm{OH}+\mathrm{H}_{2} \mathrm{O} \\
\mathrm{NH}_{2} \mathrm{OH}+\mathrm{H}_{2} \mathrm{O} \rightarrow \mathrm{NO}_{2}^{-}+5 \mathrm{H}^{+}+4 e^{-}
\end{gathered}
$$

and

$$
\mathrm{NO}_{2}^{-}+\frac{1}{2} \mathrm{O}_{2} \rightarrow \mathrm{NO}_{3}^{-}
$$

2.5.4. Denitrification

Under anaerobic or anoxic conditions, denitrifying bacteria (e.g. Pseudomonas) reduce nitrate in the presence of carbon (e.g. organic matter) to nitrogen gas forms (nitric oxide, nitrous oxide, dinitrogen). The percentage of gas emissions depends on many factors, including soil moisture (Figure 5), temperature and soil properties.

$$
\mathrm{NO}_{3}^{-} \rightarrow \mathrm{NO}_{2}^{-} \rightarrow \mathrm{NO}+\mathrm{N}_{2} \mathrm{O} \rightarrow \mathrm{N}_{2}
$$

or (anoxic conditions)

$$
2 \mathrm{NO}_{3}^{-}+10 e^{-}+12 \mathrm{H}^{+} \rightarrow \mathrm{N}_{2}+6 \mathrm{H}_{2} \mathrm{O}
$$

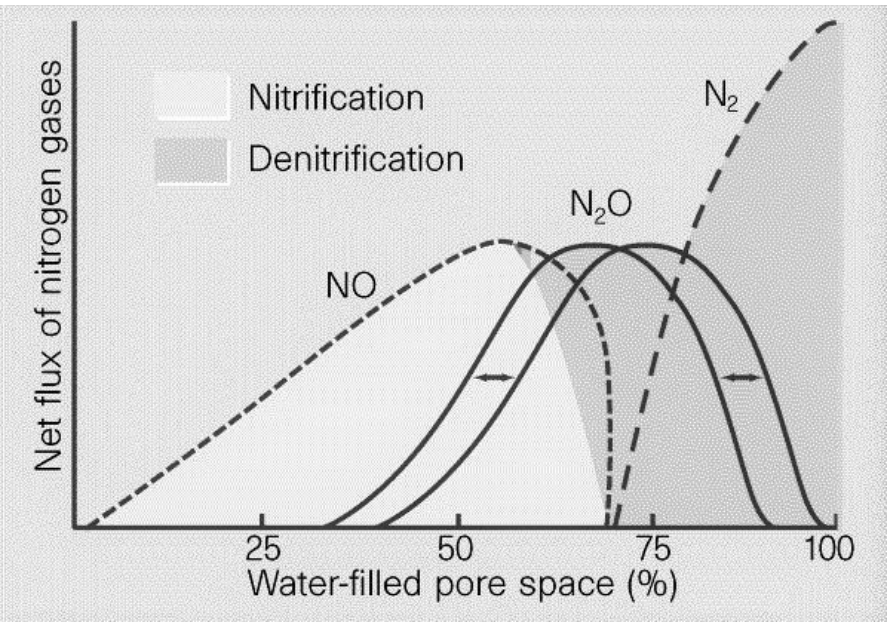

Figure 5 - Model of the relationship between water-filled pore space of soils and the relative fluxes of nitrogen gases from nitrification. (Bouwman, 1998). 


\subsubsection{Ammonia volatilization}

Ammonia volatilization is the ammonia loss to the atmosphere by the conversion of ammonium ions to ammonia gas form, due soil conditions after the ammonification (e.g. poor water content, high $\mathrm{pH}$ levels) or the application of products that contain urea (e.g. fertilizers), particularly not mixed with soil.

$$
\mathrm{NH}_{3}+\mathrm{R}-\mathrm{OH} \rightarrow 2 \mathrm{NH}_{3}(\mathrm{~g})+\mathrm{CO}_{2}
$$

or

$$
\begin{gathered}
\mathrm{NH}_{4}^{+}+\mathrm{OH}^{-} \rightarrow \mathrm{NH}_{3(a q)}+\mathrm{H}_{2} \mathrm{O} \\
\mathrm{NH}_{3(a q)} \rightarrow \mathrm{NH}_{3(\mathrm{~g})}
\end{gathered}
$$

or (after the application of urea)

$$
\begin{gathered}
\mathrm{CO}\left(\mathrm{NH}_{2}\right)_{2}+\mathrm{H}^{+}+2 \mathrm{H}_{2} \mathrm{O} \rightarrow 2 \mathrm{NH}_{4}^{+}+\mathrm{HCO}_{3}^{-} \\
\mathrm{NH}_{4}^{+}+\mathrm{OH}^{-} \rightarrow \mathrm{NH}_{4} \mathrm{OH}+\mathrm{NH}_{3(\mathrm{~g})}+\mathrm{H}_{2} \mathrm{O}
\end{gathered}
$$

2.5.6. Anammox (anaerobic ammonia oxidation)

Under anoxic conditions, anammox bacteria (e.g. Brocadia Anammoxidans) oxidize ammonium by using nitrite as the electron accepter.

$$
\mathrm{NH}_{4}^{+}+\mathrm{NO}_{2}^{-} \rightarrow \mathrm{N}_{2}+2 \mathrm{H}_{2} \mathrm{O}
$$




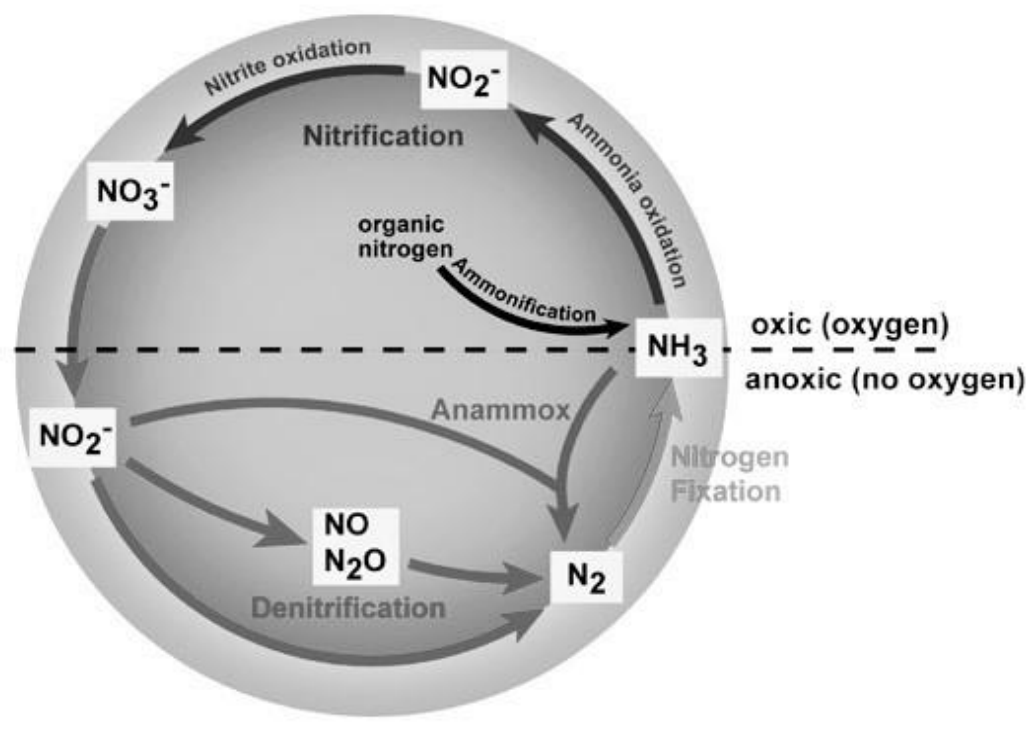

Figure 6 - Nitrogen cycle (Bernhard, 2010).

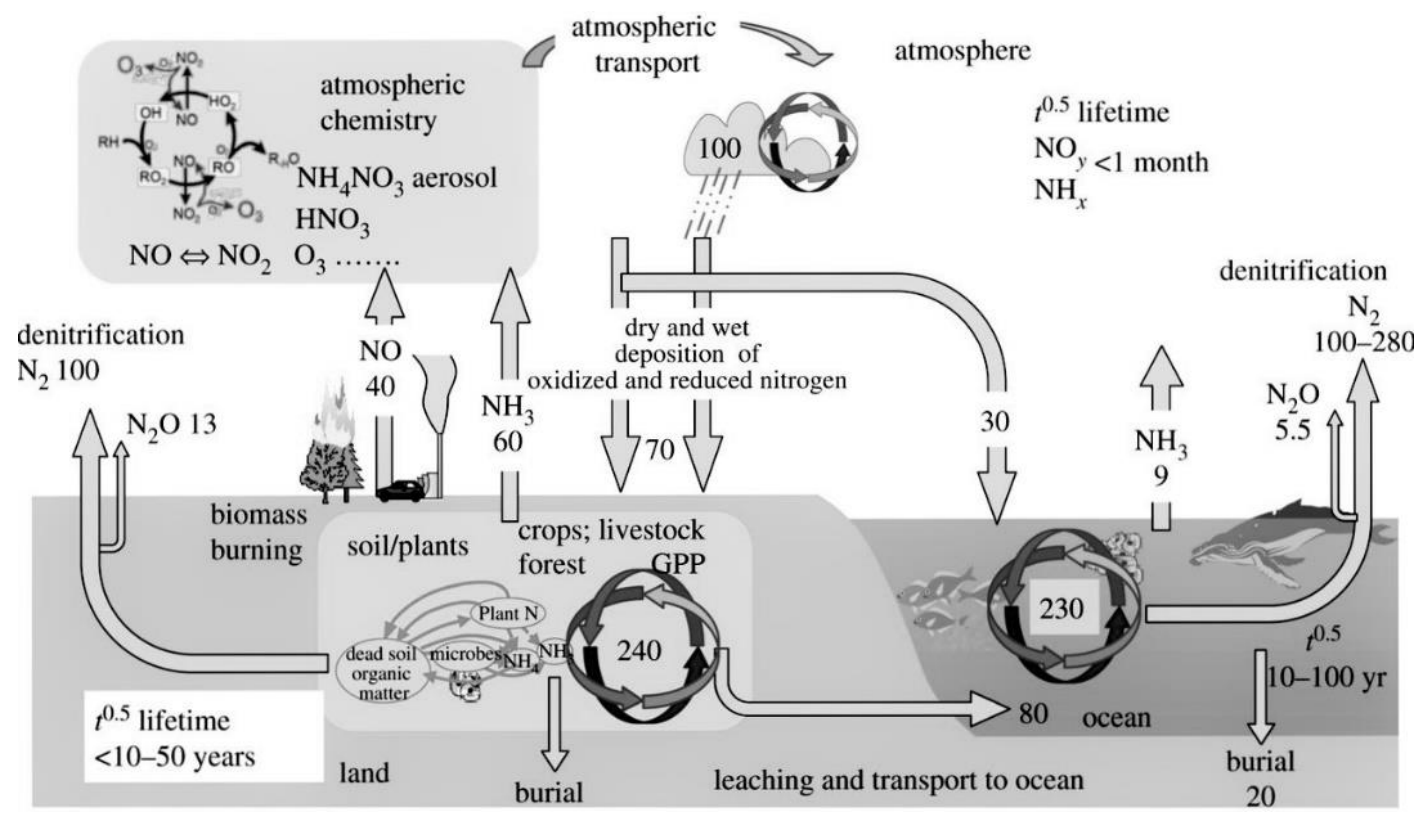

Figure 7 - The processing and fluxes of reactive nitrogen in terrestrial and marine systems and in the atmosphere $\left(T g . y r^{1}\right)$, showing the dominant forms of the reactive $N$ in the exchanges and the magnitude of the boundary fluxes, and approximate lifetimes, integrated over global scales (Fowler et al., 2013). 


\subsection{Carbon cycle}

Lithosphere is the greatest source of carbon, followed by hydrosphere, atmosphere and biosphere (Figure 9). Carbon is naturally flowed between reservoirs maintaining Earth's carbon balance. However, human activities (e.g. burn of fossil fuels) are altering carbon flows leading to negative impacts such as the global increase of temperature. According to the time-line movement of carbon, carbon cycles are classified as slow and fast.

\subsubsection{The slow carbon cycle}

The slow carbon cycle is the movement of carbon between lithosphere, hydrosphere and atmosphere that can take hundreds of millions of years.

Atmospheric carbon reacts with rain water, forming acid carbonic that falls to the surface:

$$
\mathrm{CO}_{2(a q)}+\mathrm{H}_{2} \mathrm{O} \rightleftharpoons \mathrm{H}_{2} \mathrm{CO}_{3(a q)}
$$

Rocks are dissolved by the acid carbonic, a process designed as chemical weathering (e.g. carbonation), forming bicarbonate and chemical components, such as ions, that are possible carried to water compartments:

$$
\mathrm{CaCO}_{3}+\mathrm{H}_{2} \mathrm{CO}_{3} \rightarrow \mathrm{Ca}^{2+}+2 \mathrm{HCO}_{3}^{-}
$$

Carbonate ions are released by dissociation (liberation of hydrogen ions), thereafter forming other possible compounds (e.g. water, carbon dioxide).

$$
\mathrm{HCO}_{3}^{-} \rightleftharpoons \mathrm{CO}_{3}^{2-}+\mathrm{H}^{+}
$$

On oceans, carbonate ions react with calcium to form calcium carbonate by living organisms (e.g. corals and plankton) particularly in hard waters:

$$
\mathrm{CO}_{3}^{2-}+\mathrm{Ca}^{2+} \rightarrow \mathrm{CaCO}_{3}
$$

The death of these organisms will release their carcases into seafloor, thereafter cemented by the time, generating rocks such as limestone.

The organic carbon on land from living organisms are split in the mud and if exposed to a considerable amounts of heat and pressure, can generate carbon sedimentary rocks. On the 
other hand, if the decay of the dead plant matter is lower than its accumulation, can lead to the formation of oils, coal or natural gas.

The return of the carbon to the atmosphere as carbon dioxide is made particularly through volcanoes. The collision of carbon rocks generates a large amounts of heat and pressure, causing its melting and recombination into silicate minerals (e.g. metamorphic decarbonation).

$$
\mathrm{CaCO}_{3}+\mathrm{SiO}_{2} \rightarrow \mathrm{CaSiO}_{3}+\mathrm{CO}_{2}
$$

\subsubsection{The fast carbon cycle}

The exchange of carbon between living organisms is called the fast carbon cycle, and its timeline depends on the type of organisms associated (Figure 8).

Plants and Phytoplankton (microscopic ocean organisms) absorb carbon dioxide from the atmosphere and, using sun-light as energy, combines $\mathrm{CO}_{2}$ and water to form oxygen and carbohydrates (e.g. formaldehydes) (photosynthesis):

$$
\mathrm{CO}_{2}+\mathrm{H}_{2} \mathrm{O}+\text { energy } \rightleftharpoons \mathrm{CH}_{2} \mathrm{O}+\mathrm{O}_{2}
$$

The inverse process is made by auto/heterotrophic organisms, microorganisms or even fire events, releasing carbon dioxide to the atmosphere (cellular respiration):

$$
\mathrm{CH}_{2} \mathrm{O}+\mathrm{O}_{2} \rightleftharpoons \mathrm{CO}_{2}+\mathrm{H}_{2} \mathrm{O}+\text { energy }
$$

Photosynthesis is the primarily process for soil carbon sequestration (Ontl, 2012) by removing $\mathrm{CO} 2$ from the atmosphere, stored in the form of soil organic carbon and contribute to soil organic matter.

Some anthropogenic activities, such as the substitution of natural ecosystems to croplands, are knowing as agents of natural biomass removal and accelerate organic material decomposition, leading to an unbalanced carbon cycle and the depletion of SOC. 


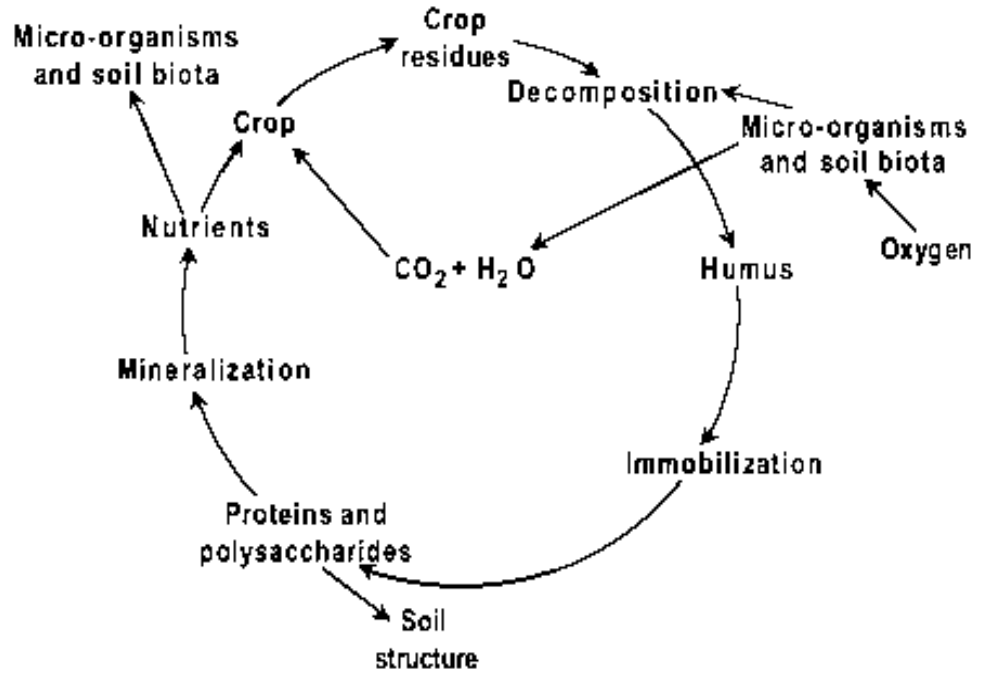

Figure 8 - Fast carbon cycle (Bot and Benites. 2005).

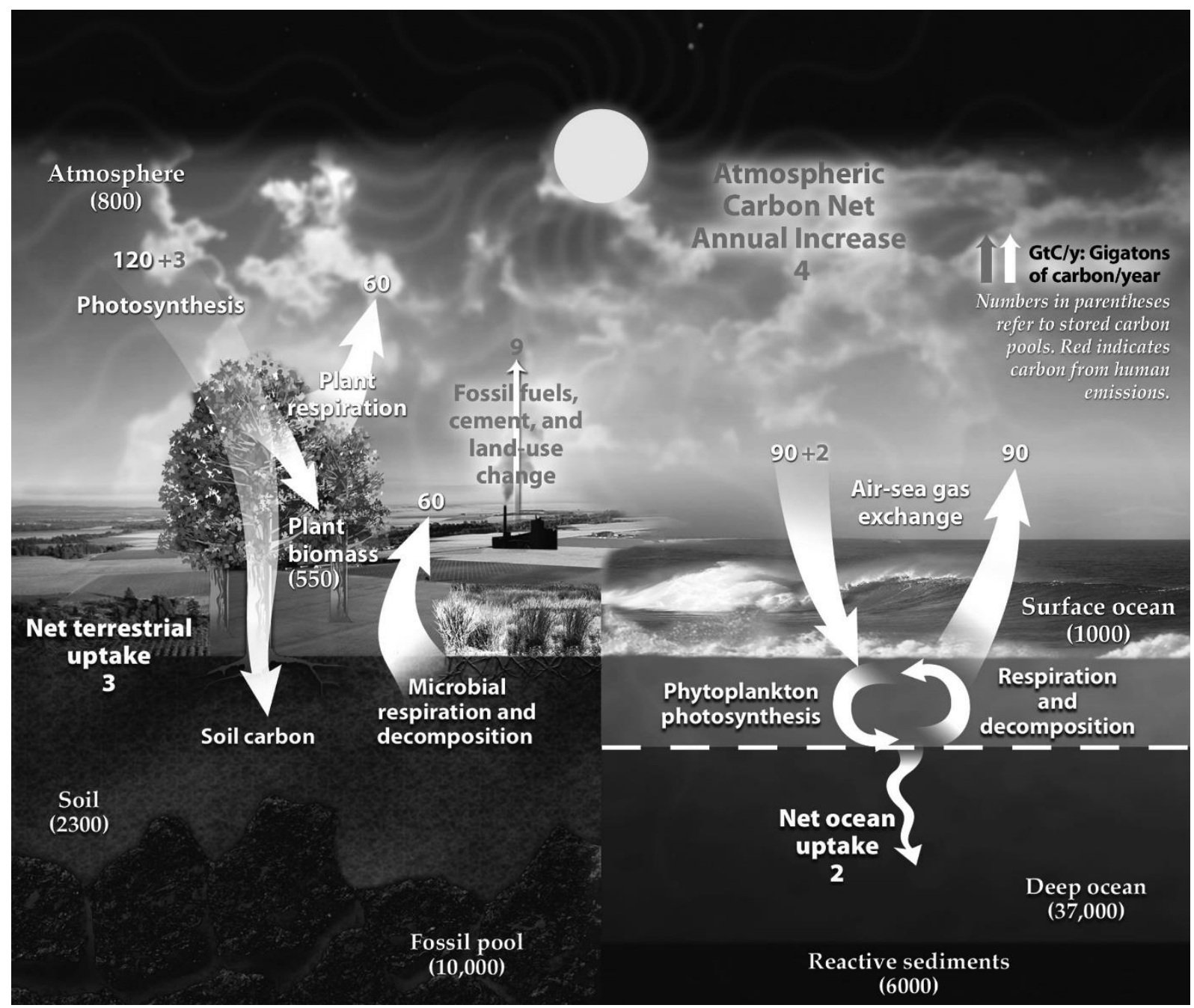

Figure 9 - Carbon cycling and biosequestration (U.S. DOE, 2008). 


\subsection{Organic matter}

Organic matter is a diverse organic material including decaying material from living organisms (plants and animals), soil microorganisms (e.g. bacteria and fungi) and soil humus (e.g. nonliving material) that affects soil properties (e.g. soil structure), increases water and plant nutrients retention, minimizing negative impacts such as soil erosion and water courses contamination. Organic carbon is the largest component of organic matter. Humus is an amorphous and complex material produced by a delay decomposition and modified organic matter over the time. Humus is constituted by humic substances (e.g. polysaccharides, fluvic acids), and around 20-40\% are non-humic compounds (Brady and Weil, 2002). While humus is associated as having a dark brown colour, colloidal nature, large organic carbon content and very low minerals, non-humic fraction can be a great source of nutrients and soil stability. Soil temperature and moisture conditions are the two major natural factors for OM accumulation followed by soil physical-chemical properties, biomass production and topography (Figure 10). In general, the increase of temperature leads to an increase of biomass net primary productivity and soil organic matter decomposition rate (Kirshbaum, 1995). On the other hand, annual precipitation is positively linked to a biomass and OM accumulation if soil moisture do not reached saturation conditions and thus poor aeration for microbial activity. Sandy texture soils and poor clay content are related to the decline of organic matter due low particles aggregation and poor formation of bonds, thereafter decreasing cation-exchange capacity and the ability of nutrients retention. Extreme $\mathrm{pH}$ levels, salinity and toxicity in soils lead to a reduction of biomass and O.M. production (Bot and Benites, 2005). 


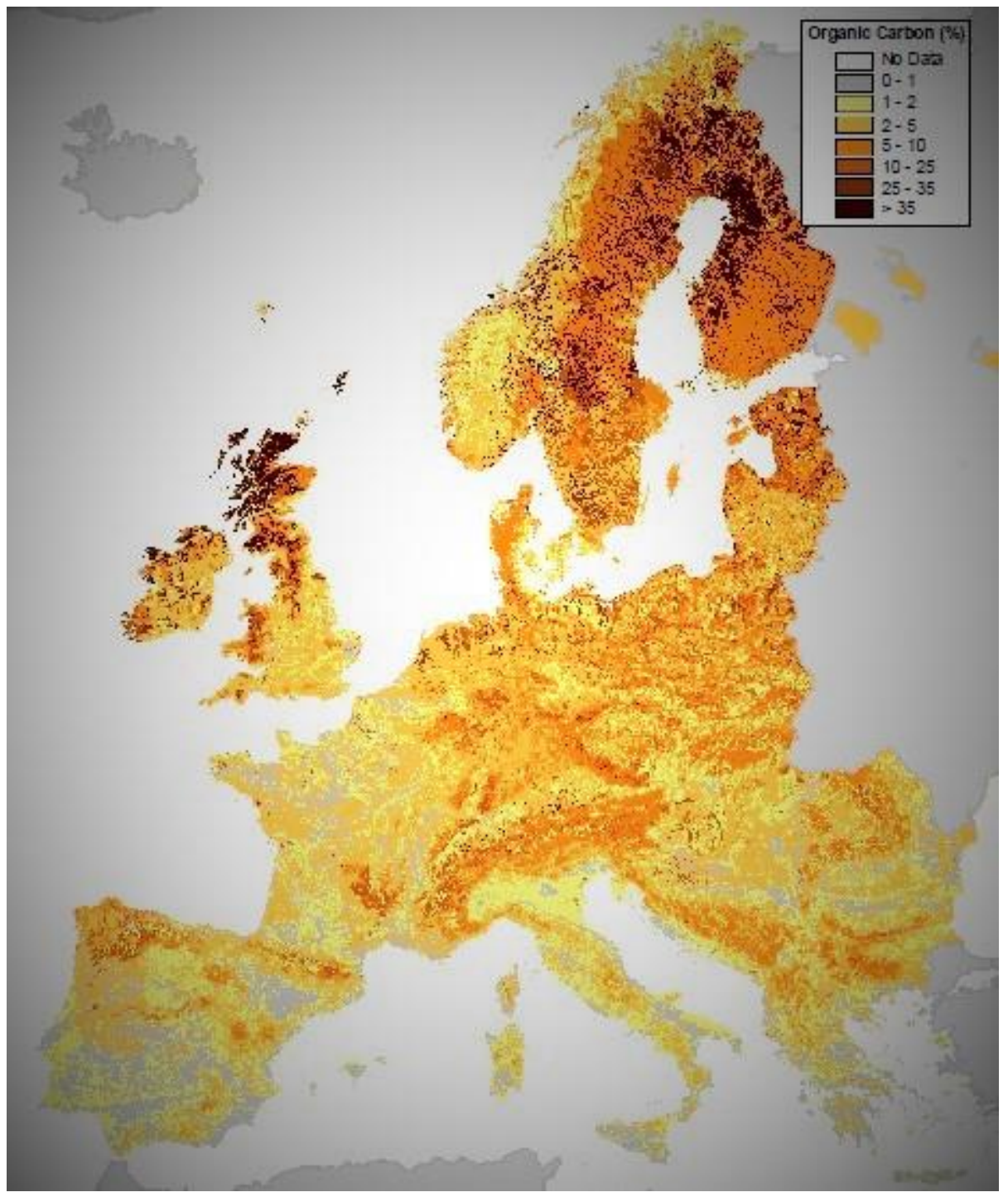

Figure 10 - Topsoil organic carbon in Europe (Jones et al., 2004).

2.8. Decomposition and mineralization of organic compounds

The decomposition of organic matter is made by soil organisms (e.g. microorganisms) that break down and biochemical transform complex organic molecules of dead material, releasing simple organic and mineral compounds. According to Ĉerný et al., (2003), the use of nitrogen fertilizers increase the decomposition rate therefore decrease the easily decomposable fraction of organic matter and microbial biomass in soil. The contribution of waste organic carbon to organic matter in agriculture soils depends on many factors such as its physicalchemical properties and environmental conditions. Neutral $\mathrm{pH}$, good aeration and water content (optimum values about $60 \%$ of WFPS) and temperatures between $25-30{ }^{\circ} \mathrm{C}$ are great conditions for almost microbial activities and therefore decomposition/mineralization 
processes. The incorporation of waste, relative to the surface application, can lead to a greater organic decomposition due its immediately contact by soil microorganisms and water content but increases nutrient losses by runoff or emissions (e.g. nitrogen volatilization).

According to Brady and Weil (2002), one year after the waste application, under aerobic conditions, around $60-80 \%$ of waste is emitted to atmosphere as carbon dioxide, $3-8 \%$ contributes for biomass (soil microorganisms) and $15-35 \%$ for humus (3-8\% of non-humic and $10-30 \%$ of complex humic compounds):

$$
R-(C, 4 \mathrm{H})+2 \mathrm{O}_{2} \rightarrow \mathrm{CO}_{2}+2 \mathrm{H}_{2} \mathrm{O}+\text { energy }
$$

$\mathrm{C}: \mathrm{N}$ ratio is a parameter mainly used for a nitrogen mineralization-immobilization turnover prediction and is influenced by several factors like soil moisture, environmental conditions, waste and soil characteristics and composition. In general, critical values are between 20 and 30 but can change according to organic material composition of waste. Lowest $\mathrm{C}: \mathrm{N}$ ratio leads to an increase of organic mineralization therefore a significant release of mineral nutrients, particularly mineral nitrogen, for plant uptake. A high C:N ratio causes microbial competition and nitrogen deficiency for plant leading to an immobilization of nutrients that are incorporated into organic molecules within living cells. Furthermore, the decomposition rate of organic carbon (or organic matter) is related to the type of organic molecules. Amide and sugars are the simplest carbon constituents readily decomposed by microorganisms and their humus contribution is lower compared to recalcitrant compounds such as lignin and waxes. Under anaerobic conditions the decomposition is made by anaerobic bacteria (e.g. methanogenic bacteria) and after precipitation events, the accumulation of $\mathrm{OM}$ tends to be greater in a partially decomposed process (Brady and Weil, 2002). Different products are released such as methane and alcohols (e.g. acetate):

$$
\begin{gathered}
4 \mathrm{C}_{2} \mathrm{H}_{5} \mathrm{COOH}+2 \mathrm{H}_{2} \mathrm{O} \rightarrow 4 \mathrm{CH}_{3} \mathrm{COOH}+\mathrm{CO}_{2}+3 \mathrm{CH}_{4} \\
\mathrm{CH}_{3} \mathrm{COOH} \rightarrow \mathrm{CO}_{2}+\mathrm{CH}_{4} \\
\mathrm{CO}_{2}+4 \mathrm{H}_{2} \rightarrow 2 \mathrm{H}_{2} \mathrm{O}+\mathrm{CH}_{4}
\end{gathered}
$$

Organic fraction represents about $20-80 \%$ of total phosphorus in the soil (Curtin et al.,, 2003). The mineralization converts organic $P$ into inorganic forms $\mathrm{H}_{2} \mathrm{PO}_{4}{ }^{-}$and $\mathrm{HPO}_{4}{ }^{-}$ (orthophosphates) and depends on the same factors than OM (e.g. temperature, moisture, aeration). Phosphorus dynamics in soil are also related to the organic carbon content (Zhang et al., 2014) and high amounts of OM thereafter its mineralization can release P-fixed into soil 
solution. C:P ratio is other parameter calculated in order to estimate phosphorus mineralization-immobilization turnover. High C:P values, normally greater than 300 , leads to a net immobilization of phosphorus and subsequently decreases $\mathrm{P}$ available for plant uptake. On the other hand, C:P values lower than 200 increases $P$ mineralization and the activity of $P$ fixed bacteria.

$$
\begin{gathered}
\text { Organic P comp. } \rightarrow \mathrm{H}_{2} \mathrm{PO}_{4}^{-} \\
\mathrm{H}_{2} \mathrm{PO}_{4}^{-} \rightleftharpoons \mathrm{HPO}_{4}^{-2}+\mathrm{H}^{+} \rightleftharpoons \mathrm{PO}_{4}^{-2}+H^{+}
\end{gathered}
$$

Organic wastes can easily provide great amounts of readily $\mathrm{K}$ forms (exchangeable and soluble $\mathrm{K}$ ) due the non-incorporation of $\mathrm{K}$ into organic compounds, remaining in the ionic form $\left(\mathrm{K}^{+}\right)$. Only, approximately, $1-2 \%$ of total soil $\mathrm{K}$ are in the readily form due the high persistent to weathering of minerals (e.g. micas and feldspar crystals) that are the greatest source of potassium.

nonexchangeable $K \rightleftharpoons$ exchangeable $K \rightleftharpoons$ soil solution $K$

\subsection{Yeast waste}

Lallemand Ibéria, S.A. is a biotechnology company with specialization in the production of yeast, live microorganisms of the species Saccharomyces cerevisiae. Liquid, pressed and dry yeast are the final products and around $70 \%$ are exported over the world. Yeast is produced by pure cultures of the Saccharomyces cerevisiae strain (Lallemand Ibéria, S.A., 2016). Beet or cane molasses are the main raw material used to supply the necessary sugar for the yeast cell growth. Pure culture of yeast are introduced into a fermenter containing sterilized molasses and other nutrients such as ammonia, diammonium phosphate, magnesium sulphate and vitamins. The developed culture is introduced into a principal fermenter and fed with molasses and nutrients. Adequate conditions such as aeration, temperature and $\mathrm{pH}$ are required. Water is used in order to keep the optimum range temperature for the fermentation process. During the alcohol fermentation, yeast waste (CMS) is obtained from the processing and separation of yeast from must, rich in proteins, carbohydrates, vitamins and some minerals. Decanted yeast waste (CMSd) is obtained by the decantation of yeast waste.

Previous studies concluded that yeast applied in soil can be a great source of nutrients for plant growth (Pita et al., 2010) leading to a mineralization of organic compounds. However, due its high organic content and labile carbon, yeast can stimulated $\mathrm{CO}_{2}$ production (Rezende 
et al., 2004) and increase nitrate and phosphorus leaching. Electrical conductivity can also be high in some yeast wastes and its indiscriminate use may affect the physical and chemical properties of soil (Hati et al., 2007) as the increase of osmotic pressure, consequently water loss available and soil toxicity.

There are a few reports about other possible destinations beyond the nutrient management of yeast waste. Neira and Jeison (2010) showed that the anaerobic co-digestion of surplus yeast and brewery wastewater is feasible due high organic matter content of yeast. AD has become an attractive sustainable treatment for biodegradable organic wastes (Zupančič and Grilc, 2012), producing biogas, composed mainly by methane and dioxide carbon, for renewable energy production. In fact, one of Union European energetic and climatic objectives for 2020 is the obtaining of $20 \%$ of energy through renewable sources (Union European, 2016).

\subsection{Bibliography}

Alvarenga, P., Mourinha, C., Farto, M., Palma, P., Sengo, J., Morais, M.C., Cunha-Queda, C., 2015. Ecotoxicological assessment of the potential impact on soil porewater, surface and groundwater from the use of organic wastes as soil amendments. Ecotoxicology and Environmental Safety, 126, 102-110.

Bernal, M.P., Sánchez-Monedero, M.A., Paredes, C., Roig, A., 1998. Carbon mineralization from organic wastes at different composting stages during their incubation with soil. Agriculture, Ecosystems \& Environmental, 69(3), 175-189.

Bernhard, A., 2010. The nitrogen cycle: processes, players, and human impact. Nature Education Knowledge, 3(10), 25.

Bot, A., Benites, J., 2005. The importance of soil organic matter - Key to drought-resistant soil and sustained food and production. Food and Agriculture Organization of the U.S. publications.

Bouwman, A.F., 1998. Environmental science: Nitrogen oxides and tropical agriculture. Nature, 392, 866-867.

Brady, Nyle C., Weil, Ray R., 2002. The nature and properties of soils. $13^{\text {th }}$ Ed.

Ĉerný, J., Balík, J., Pavlíková, D., Zitková, M., Sýkora, K., 2003. The influence of organic and mineral nitrogen fertilizers on microbial biomass nitrogen and extractable organic nitrogen in long-term experiments with maize. Plant Soil Environment, 49(12), 560-564. 
Curtin, D., McCallum, F.M., Williams, P.H., 2003. Phosphorus in light fraction organic matter separated from soils receiving long-term applications of superphosphate. Biology and Fertility of Soils, 37, 280-287.

Diacono, M., Montemurro, F., 2010. Long-term effects of organic amendments on soil fertility. A review. Agronomy for Sustainable Development, 30, 401-422.

Djodjic, F., Bergstrom, L., 2005. Phosphorus losses from arable fields in Sweden: effects of field specific factors and lon-term trends. Environmental Monitoring and Assessment, 102(1), 103-117.

DOE, U.S., 2008. Carbon cycling and biosequestration: Integration biology and climate through systems science. Carbon cycling and biosequestration workshop.

EPA, 2016. Climate change science. Overview of climate change science.

Fangueiro, D., Coutinho, J., Cabral, F., Fidalgo, P., Bol, R., Trindade, H., 2012. Nitric oxide and greenhouse gases emissions following the application of different cattle slurry particle size fractions to soil. Atmospheric Environmental, 47, 373-380.

Fangueiro, D., Surgy, S., Napier, V., Menaia, J., Vasconcelos, E., Coutinho, J., 2014. Impact of slurry management strategies on potential leaching of nutrients and pathogens $n$ a sandy soil amended with cattle slurry. Journal of Environmental Management, 146, 198-205.

FAO, 2016. FAOSTAT emissions database, agriculture, agriculture total.

Fortune, S., Lu, J., Addiscott, T.M., Brookes, P.C., 2005. Assessment of phosphorus leaching losses from arable land. Plant and Soil, 269, 99-108.

Fowler, D. et al, 2013. The global nitrogen cycle in the twenty-first century. Phil Trans R Soc B.

Gilbert N., 2012. One-third of our greenhouse gas emissions come from agriculture. Nature News.

Hati, K.M., Biswas, A.K., Bandyopadhyay, K.K., Misra, A.K., 2007. Soil properties and crop yields on a vertisol in India with application of distillery effluent. Soil \& Tillage Research, 92, 60-68.

lacurci, J., 2015. Humans erode soil 100 times faster than nature. Nature World News, Environment. 
IPCC, 2007. Climate Change 2007: Mitigation. Contribution of working group III to the fourth assessment report of the intergovernmental panel on climate change [B. Metz, O.R. Davidson, P.R. Bosch, R. Dave, L.A. Meyer (Ed.)]. Cambridge University Press, Cambridge, United Kingdom and New York, NY, USA.

Jones, R.J.A., Hiederer, R., Rusco, E., Loveland, P.J., Montanarella, L., 2004. Estimating organic carbon in the soils of Europe for policy support. European Journal of Soil Science, 56, 655-671.

Kirshbaum, M.U.F., 1995. The temperature dependence of soil organic matter decomposition and the effect of global warming on soil organic storage. Soil Biology and Biochemistry, 27(6), 753-760.

Kotschi, J., 2015. A soiled reputation: Adverse impacts of mineral fertilizers in tropical agriculture. Heinrich Böll Foundation and WWF Germany, 1-58.

Kolahchi, Z., Jalali, M., 2007. Effect of water quality on the leaching of potassium from sandy soil. Journal of Arid Environments, 68(4), 624-639.

Larchevêque, M., Baldy, V., Montès, N., Fernandez, C., Bonnin, G., Ballini, C., 2006. Shortterm effects of sewage-sludge compost on a degraded Mediterranean soil. Soil Science Society of America Journal, 70, 1178-1188.

Lehmann J., Schroth G., 2003. Nutrient leaching. Trees, crops and soil fertility: concepts and research methods, 151-166.

Li, Y.C., Stoffella, P.J., Alva, A.K., Calvert, D.V., Graetz, D.A., 1997. Leaching of Nitrate, Ammonium, and Phosphate From Compost Amended Soil Columns. Compost Science \& Utilization, 5(2), 63-67.

Loehr, R.C., 1974. Environmental impact. Agricultural waste management: problems, processes and approaches, 46-94.

Neira K., Jeison D., 2010. Anaerobic co-digestion of surplus yeast and wastewater to increase energy recovery in breweries. Water Science and Technology, 61, 1129-1135.

Ontl, T.A., Schutle, L.A., 2012. Soil carbon storage. Nature Education Knowledge 3(10), 35.

Pita V., Vasconcelos E., Fangueiro D., Cabral F., Ribeiro H.M., 2010. Carbon and nitrogen mineralization of organic wastes from sugarcane distilleries: vinasse and yeast waste. Treatment and use of non-conventional organic residues in agriculture, UTL Repository. 
Rezende, L.A., Assis, L.C., Nahas, E., 2004. Carbon, nitrogen and phosphorus mineralization in two soils amended with distillery yeast. Bioresource Technology, 94, 159-167.

Riebeek H., 2011. The carbon cycle. Feature articles, NASA.

Rosolem, C.A., Sgariboldi, T., Garcia, R.A., Calonego, J.C., 2010. Potassium leaching as affected by soil texture and residual fertilization in tropical soils. Communications in soil science and plant analysis, 41(16), 1934-1943.

Shen, J., Yuan, L., Zhang, J., Li, H., Bai, Z., Chen, X., Zhang, W., Zhang, F., 2011. Phosphorus dynamics: from soil to plant. American Society of Plant Biologists, 156, 997-1005.

Sparks, D.L., 2001. Dynamics of $\mathrm{K}$ in Soils and Their Role in Management of $\mathrm{K}$ Nutrition. Advances in Soil Science: Potassium Dynamics in Soils, 6, 1-63.

UNEP-IETC/ILEC, 2001. Groundwater: Water flowing under the land surface. Lakes and reservoir: The watershed: Water from mountains into the sea, 2, 26-30.

Yaalon, D.H., 1997. Soils in the Mediterranean region: what makes them different?. CATENA, 28(3-4), 157-169.

Zhang, L., Ding, X., Chen, S., He, X., Zhang, F., Feng, G., 2014. Reduction carbon: phosphorus ratio can enhance microbial phytin mineralization and lessen competition with maize for phosphorus. Journal of Plant Interaction, 9(1), 850-856.

Zupančič, G.D., Grilc, V., 2012. Anaerobic treatment and biogas production from organic waste. Management of organic waste, Dr. Sunil Kumar (Ed.). 
3. Results and discussion: research article 


\title{
Assessment of the environmental impact of yeast waste application to soil: an integrated approach
}

\author{
Ricardo Mata ${ }^{1}$, Sandro Ratinho², David Fangueiro ${ }^{{ }^{*}}$ \\ ${ }^{1}$ LEAF, Instituto Superior de Agronomia, Universidade de Lisboa, Tapada da Ajuda, 1349-017 \\ Lisboa, Portugal \\ ²allemand Ibéria, S.A. \\ "corresponding author: dfangueiro@ulisboa.pt
}

Abstract

The yeast production industry (e.g. distillery, brewing, baking industries) has been growing globally over the last years generating a large amount of sub-products. Laboratory experiments, under controlled conditions, were performed to investigate the impact of yeast waste application to a sandy texture soil. Experimental treatments were: surface application of yeast and decanted-yeast (CMSs and CMSds), surface application of yeast and decantedyeast followed by incorporation in the $0-5 \mathrm{~cm}$ soil layer (CMSm and CMSdm), surface application of ammonium nitrate (AN) (not applied in short-term experiment) and a control (soil only) (CTR). The amount of yeast applied was $2 \mathrm{~g}$ in the short-term experiment and equivalent to $170 \mathrm{kgN} \cdot \mathrm{ha}^{-1}$ in the long-term experiment. A short-term (38-day period) leaching experiment was performed with 5 weekly irrigation events ( 5 treatments $\times 3$ replications) to assess $N, P$, $\mathrm{K}$ losses. Results showed that yeast application increased $\mathrm{NH}_{4}{ }^{+}, \mathrm{P}_{\mathrm{T}}$ and $\mathrm{K}_{\mathrm{T}}$ leaching relative to control while decreased $\mathrm{NO}_{3}{ }^{-}$leaching relative to a high initial content of control, during first irrigation events. Incorporation treatments increased $\mathrm{NH}_{4}{ }^{+}, \mathrm{NO}_{3}{ }^{-}$and $\mathrm{P}_{\mathrm{T}}$ losses earlier. $\mathrm{K}_{\mathrm{T}}$ losses were higher in surface treatments. A long-term leaching experiment (73-day period) with 6 irrigation events every two weeks was performed ( 6 treatments $\times 4$ replicates) to assess $\mathrm{N}, \mathrm{P}$ losses. A two parallel incubation experiment (6 treatments $\times 3$ replicates) were simultaneously performed to measure $\mathrm{GHG}$ emissions $\left(\mathrm{CO}_{2}, \mathrm{~N}_{2} \mathrm{O}, \mathrm{CH}_{4}\right)$ and to assess the $\mathrm{N}$ mineralization in each treatment. Results showed that yeast application increased initial $\mathrm{NH}_{4}{ }^{+}$ concentration in leachates and soil relative to control and $\mathrm{NO}_{3}{ }^{-}$increased afterwards. $\mathrm{N}_{2} \mathrm{O}$ and $\mathrm{CO}_{2}$ increased significantly relative to control on the first days after yeast application. AN 
treatment emissions were very similar to control but had a small increase of $\mathrm{N}_{2} \mathrm{O} . \mathrm{CH}_{4}$ emissions were insignificant. The global warming potential (GWP) of yeast and AN were $6 \times$ and $2 \times$ times higher than control, respectively.

Keywords: Yeast, soil, groundwater, pollution, greenhouse gases

\section{A. Introduction}

Earth is a dynamic planet covered with life-sustaining air, water and soil that are in constant energetic and material interaction. The environmental quality depends on the waste management as a source of nutrients for soil, leading to improvement of their physical, chemical and biological properties. The impact of nutrient management is more focused in the area of water quality (Brady and Weil, 2002) due to runoff and infiltration to groundwater of pollutions such as nitrates and phosphorus, but also in the atmospheric compartment due to the issue of greenhouse gaseous effects.

The Mediterranean area is typically characterized as having a degraded soil exposed to large climatic variations, low content of $\mathrm{P}, \mathrm{N}$ and organic matter, particularly in topsoil, and consequently eroded. (Larchevêque et al., 2006; Diacono and Montemurro 2010). The intensive use of mineral fertilizers in agricultural practice is not only responsible for the environmental degradation but as well as by the decrease of organic matter and deleterious effects on crop growth. Organic wastes with high organic content are an excellent potential source of plant nutrients, particularly potassium and nitrogen, which may be applied as an organic fertilizer thereby reducing landfill disposal and ensuring the recycling of nutrients and soil fertility (Alvarenga et al., 2015; Rezende et al., 2004). On the other hand, there is a concern about environmental pollution on the defective implementation of this type of waste in the environmental due to its high organic content and low pH (Pita et al., 2010). Sometimes undesired substances can be found in these wastes, such as heavy metals and pathogens, which will lead to a greater negative impact on the quality of agricultural products, biodiversity and human health (Alvarenga et al., 2015). As nutrients contents can be high in some of these wastes (Li et al., 1997), its application at high rates may lead to contamination of groundwater by nutrients not absorbed by plants. Nitrate is highly mobile in soil due its insignificant interaction to the negative charged matrix. According to the Nitrate Directive (91/676/CEE), groundwater courses are considered polluted if nitrate levels reached $50 \mathrm{mg} . \mathrm{L}^{-1}$, corresponding to the maximum allowable value. Ammonium concentrations in soil solution normally are very low due its high retention but can increase in soils with a sandy texture and low cation- 
exchange capacity (Fangueiro et al., 2014). The concern about phosphorus losses from arable soils has increased, particularly in marine habitats, due the eutrophication in freshwater systems, promoting algae and aquatic weed growth. However, P losses by leaching are neglected due to the large retention capacity of $P$ of most soils, and even with large amounts of water's input (Fortune et al., 2005). Furthermore, phosphorus dynamics depend highly on $\mathrm{pH}$ levels. At low pH levels, phosphate can be adsorbed by iron ( $\mathrm{Fe}$ ) and aluminum ( $\mathrm{Al}$ ) oxides (particles with anion exchange capacity). On the other hand, in alkaline soils tend to form compounds with Calcium ( $\mathrm{Ca}$ ). Potassium is a mobile ion in soils and consequently significant amounts can be lost by leaching. Leaching of $\mathrm{K}$ is often a problem on sandy soils due its low clay content and poor interaction of $\mathrm{K}^{+}$with the soil matrix. Losses of $\mathrm{K}^{+}$depends mainly on the $\mathrm{CEC}$, soil texture, $\mathrm{pH}$ and Calcium concentrations. Normally, a low potassium leaching is observed at $\mathrm{pH}$ levels between 6-6.5 (Sparks, 2001) due to enhanced substitution of $\mathrm{K}$ for $\mathrm{Ca}$ by its competition in the leaching water and the amount of water that passes through the soil.

Greenhouse gases from human activities are the most significant driver of observed climate change since the mid-20th century (IPCC, 2013). Gaseous emissions such as carbon dioxide, nitrous oxide and methane are the three of the main greenhouse gases contributing to ecosystems change and global warming (Fangueiro et al., 2012) and most of emissions comes from the agricultural and livestock sector due the use of synthetic fertilizers and biological processes (FAO, 2016). Indeed, biological processes these sectors and other sources (e.g. swamp gas) are the largest responsible for the strongly increase of global methane levels in atmosphere. Agriculture practice, including food systems, is responsible for about one-third of GHG emissions, and climate change probably will cause yields drop (Gilbert, 2012). Under aerobic conditions, $\mathrm{N}_{2} \mathrm{O}$ gets special attention in agricultural activities due the application of wastes with high nitrogen content plus environmental conditions.

Yeast waste is obtained from the processing and separation of yeast from must, rich in proteins, carbohydrates, vitamins and some minerals, generated during the alcoholic fermentation. Molasses from beet or cane is the main raw material used to supply the necessary sugar to the development of yeast cells. Previous studies concluded that yeast applied in soil can be a great source of nutrients for plant growth (Pita et al., 2010) leading to a mineralization of organic compounds. However, due its high organic content and labile carbon, yeast can stimulated $\mathrm{CO}_{2}$ production (Rezende et al., 2004) and increase nitrate and phosphorus leaching. Electrical conductivity can also be high in some yeast wastes and its indiscriminate use may affect the physical and chemical properties of soil (Hati et al., 2007). 
The main objective of this study was to assess the impact of two yeast wastes (CMS and decanted CMS) application to an acidic sandy textured soil sandy, the potential leaching of nutrients through soil columns in two independent experiments (short and long-term), as well as the nitrogen mineralization in soil and greenhouse gas emissions in an aerobic incubation. A secondary objective was to compare the difference between the surface application of yeast waste and the surface application followed by incorporation in the $0-5 \mathrm{~cm}$ soil layer. 
B. Materials and methods

B.1. Soil and yeast waste

The soil was collected in Palmela, Portugal, in an agricultural field not fertilized since more than ten years, classified according to World Reference Base (WRB) as Haplic arenosol, equivalent to regosol in 'Serviço de reconhecimento e ordenamento agrário (SROA)' classification, with coarser texture than sandy loam to at least $100 \mathrm{~cm}$, without fluvic or 'ândicas' properties. Disturbed soil columns were used for the short-term leaching experiment while undisturbed soil columns were used in the long-term leaching experiment. The soil used in the aerobic incubation and short-term leaching experiment was air dried, sieved at $2 \mathrm{~mm}$ and then stored until used. The main characteristics of the soil are presented in Table 1.

Table A1 - Physical-chemical analysis of soil sample

Characteristic Unit Value

Soil particle

size

Clay $\quad$ g. $\mathrm{kg}^{-1} \quad 33$

Silt $\quad$ g.kg-1 45

Sand $\quad$ g.kg-1 922

Organic C $\quad$ g. $\mathrm{kg}^{-1} \quad 8.8$

Bulk density $\quad \mathrm{g} . \mathrm{cm}^{-3} \quad 1.49$

Porosity $\quad \mathrm{cm}^{3} \cdot \mathrm{cm}^{-3} \quad 0.48$

WFPS $\quad$ g.kg $^{-1} \quad 220$

$\begin{array}{lll}\mathrm{pH} & \mathrm{H}_{2} \mathrm{O} & 5.71\end{array}$

CEC $\quad$ Cmol $_{\text {c.kg }} \quad 2.94$

$\begin{array}{lll}\text { Base } & \% & 93.6\end{array}$

saturation

EC $\quad$ g. $\mathrm{kg}^{-1} \quad 74.5$

Total N $\quad$ g. $\mathrm{kg}^{-1} \quad 0.92$

$\mathrm{NH}_{4}{ }^{+}-\mathrm{N} \quad \mathrm{mg} \cdot \mathrm{kg}^{-1} \quad 7.5$

$\mathrm{NO}_{3}{ }^{-}-\mathrm{N} \quad$ mg.kg-1 43.38

$\begin{array}{ll}\text { Corg:N } & 9.57\end{array}$ 
Yeast waste was provided by Lallemand S.A. from the production unit located in Setubal (Portugal). Two different by-products were used in the present study: CMS and decanted CMS. The main characteristics of both waste are shown below.

Table A2 - Chemical analysis of yeast waste

\begin{tabular}{llll} 
Characteristic & Unit & CMS & CMSd \\
\hline Dry matter & $\%$ & 54.25 & 62.17 \\
pH & & 6.24 & 6.58 \\
EC & mS.cm & 25.50 & 27.60 \\
& 1 & &
\end{tabular}

Organic C $\quad$ g.kg $^{-1} \quad 137.20 \quad 103.60$

$\begin{array}{llll}\mathrm{N}_{\mathrm{T}} & \mathrm{g} \cdot \mathrm{kg}^{-1} & 25.56 & 24.71\end{array}$

$\mathrm{NH}_{4}{ }^{+}-\mathrm{N} \quad$ g. $\mathrm{kg}^{-1} \quad 1.05 \quad 0.79$

$\begin{array}{llll}\mathrm{NO}_{3}-\mathrm{N} & \mathrm{g} \cdot \mathrm{kg}^{-1} & 0.21 & 0.17\end{array}$

$\begin{array}{llll}\mathrm{P}_{\mathrm{T}} & \text { g. } \mathrm{kg}^{-1} & 0.59 & 1.19\end{array}$

$\begin{array}{llll}\mathrm{K}_{\mathrm{T}} & \mathrm{g} \cdot \mathrm{kg}^{-1} & 32.45 & 68.18\end{array}$

$\mathrm{Na} \quad$ g.kg-1 $\quad 55.09 \quad 57.98$

$\begin{array}{llll}\mathrm{Ca} & \text { g.kg-1 } & 2.76 & 10.57\end{array}$

$\begin{array}{llll}\mathrm{Mg} & \mathrm{g} \cdot \mathrm{kg}^{-1} & 0.70 & 1.03\end{array}$

$\begin{array}{llll}\mathrm{Fe} & \mathrm{mg} \cdot \mathrm{kg}^{-1} & 69.77 & 51.6\end{array}$

$\begin{array}{llll}\mathrm{Cu} & \mathrm{mg} . \mathrm{kg}^{-1} & 3.23 & 3.14\end{array}$

$\begin{array}{llll}\mathrm{Zn} & \mathrm{mg} \cdot \mathrm{kg}^{-1} & 10.01 & 8.90\end{array}$

$\begin{array}{llll}\text { Mn } & \text { mg.kg-1 } & 7.97 & 15.18\end{array}$ 


\section{B.2. Experimental design}

\section{B.2.1. Short-term experiment}

In the first short-term experiment, potential nutrients leaching from yeast amended soils was assessed. For this, PVC tubes (30 cm long, $5.5 \mathrm{~cm}$ internal diameter) were sealed at the bottom with a geotextile membrane and PVC net in order to avoid soil losses. $1 \mathrm{~kg}$ of soil was weighed for each tube and compacted up to a depth of $25 \mathrm{~cm}$. To initiate the experiment, tubes were placed in a container with deionized water and were left during 2 days to allow its upward flow and soil saturation. 5 treatments ( 3 times replicated) were considered: surface application of CMS (CMSs) and decanted CMS (CMSds), surface application and subsequent soil incorporation in the $0-5 \mathrm{~cm}$ layer of CMS (CMSm) and decanted CMS (CMSdm), and control with no application (CTR). For each CMS treatment $2 \mathrm{~g}$ of waste were applied. These value was chosen as a medium value between the maximum $\mathrm{N}$ application allowed $(240 \mathrm{~kg} \mathrm{~N}$.ha${ }^{1}$ year $^{-1}$ ) in agriculture soils and the maximum $\mathrm{N}$ application allowed in vulnerable areas (170 kg N.ha ${ }^{-1}$.year ${ }^{-1}$ ) in Portugal. 4 Irrigation events were performed with deionized water application for each tube weekly and 1 last after two weeks. The first event started three days after the application of yeast. The amount of water applied in each event was $300 \mathrm{~mL}$, a volume higher than the maximum retention capacity, in order to allow the total leaching of water content already present in the soil saturated. The water flow rate in each tube was approximately 4.2 $\mathrm{mL}$ per minute. For each event, two leaching samples were collected in plastic bottles, the first sample was made as the amount of leached equal to $220 \mathrm{~g}$ and the second sample was the excess, considered approximately $80 \mathrm{~g} .1$ week after the experiment, soil columns were destroyed in four layers with $6 \mathrm{~cm}$ height each and were analysed. The temperature of experiment was $25^{\circ} \mathrm{C}$. 


\section{B.2.2. Long-term experiment}

In the long-term experiment, two independent studies were performed: a first one to assess potential leaching of nutrients with moderate rainfalls and a second one where GHG emissions and $\mathrm{N}$ mineralization were followed in soil amended with yeast wastes.

\section{B.2.2.1. Long-term leaching experiment}

PVC tubes (30 cm long, $5.5 \mathrm{~cm}$ internal diameter) were insert into soil to a depth of $28 \mathrm{~cm}$ and sealed at the bottom with a geotextile membrane and PVC net in order to enable the leachate drainage material. The average weight of moist soil in each tube was $1.15 \mathrm{~kg} .6$ treatments were considered, 4 replications each: surface application of CMS (CMSs) and decanted CMS (CMSds), surface application and subsequent soil mix in the $0-5 \mathrm{~cm}$ layer of CMS (CMSm) and decanted CMS (CMSdm), surface application of ammonium nitrate (AN) and control with no application (CTR). The amount of waste and ammonium nitrate applied was calculated in order to corresponding the maximum $\mathrm{N}$ value allowed in vulnerable areas $\left(170 \mathrm{~kg} \mathrm{~N} \mathrm{ha}^{-1}\right.$.year $\left.{ }^{-1}\right)$ in Portugal. After each irrigation event, tubes were weighed in order to calculate the moisture content in soil. Leached samples were collected in plastic bottles, weighed and used for determination of $\mathrm{pH}, \mathrm{EC}, \mathrm{N}$ mineral and phosphorus. The temperature of experiment was 25 ${ }^{\circ} \mathrm{C}$. 6 Irrigation events were performed with deionized water application every two weeks. The first event started three days after the application of yeast. The amount of water applied in each event was $300 \mathrm{~mL}$, a volume higher than the maximum retention capacity of soil (approximately 22\% (water mass:soil mass)), in order to allow the total leaching of water content already present in the soil saturated. Leachates were collected into plastic bottles, weighted and analysed. The water flow rate in each tube was approximately $2.1 \mathrm{~mL}$ per minute. 


\section{B.2.2.2. GHG emissions and Nitrogen mineralization experiment}

For aerobic incubations, Kilner jars (18 cm height, $10 \mathrm{~cm}$ length, $10 \mathrm{~cm}$ width) were used with a Teflon tube (10 cm long, $4 \mathrm{~mm}$ diameter) kept $2 \mathrm{~cm}$ above the soil surface. In order to collect gas samples, a PVC O-ring was inserted at the outside end of the Teflon tube. Approximately $1.37 \mathrm{~kg}$ of dry soil were weighed for each Kilner jar, equivalent to a $10 \mathrm{~cm}$ depth. The soil moisture was corrected six times, every two weeks, starting at the day zero, in order to contain the same moisture content calculated in leaching experiment PVC tubes. 6 treatments were considered, 3 replications each: surface application of CMS (CMSs) and decanted CMS (CMSds), surface application and subsequent soil mix in the $0-5 \mathrm{~cm}$ layer of CMS (CMSm) and decanted CMS (CMSdm), surface application of ammonium nitrate (AN) and control with no application (CTR). The amount of waste and ammonium nitrate applied was calculated in order to corresponding the maximum $\mathrm{N}$ value allowed in vulnerable areas $\left(170 \mathrm{~kg} \mathrm{~N} \mathrm{ha}^{-1}\right.$.year $\left.{ }^{-1}\right)$ in Portugal. The collection of gas samples were performed on days $0,1,2,3,6,8,10,13,15$, $17,20,22,24,27,29,31,36,43,50,64$ and 78 (21 sampling dates). $\mathrm{CH}_{4}, \mathrm{~N}_{2} \mathrm{O}$ and $\mathrm{CO}_{2}$ fluxes were measured using modified lids fitted with two septa $(\varnothing 1 / 410 \mathrm{~mm})$ and a Teflon tube $(\varnothing 1 / 4$ $4 \mathrm{~mm}, \mathrm{H} 1 / 4100 \mathrm{~mm}$ ) to allow air sampling. The first gas sample was immediately taken (timezero sample (TO)) after closing Kilner jars, using a syringe and flushed through evacuated 20 $\mathrm{mL}$ gas vials. After $0.5 \mathrm{~h} \mathrm{(T1)}$ and $1 \mathrm{~h}$ (T2) of closure other gas samples were collected. he concentration of gas samples stored in vials were measured by gas chromatography (GC) using a GC-2014 (Shimadzu, Japan) equipped with an electron capture 63Ni detector (ECD), a thermal conductivity detector (TCD) and a flame ionization detector (FID) for $\mathrm{N}_{2} \mathrm{O}$, and analysis, respectively. The GC accuracy was 50 ppbe100 ppm for $\mathrm{N}_{2} \mathrm{O}, 1 \mathrm{ppm}$ to $1 \%$ for $\mathrm{CO}_{2}$ and $0.1 \mathrm{ppm}$ to $1 \%$ for $\mathrm{CH}_{4}$. Gas fluxes were calculated by fitting linear regressions through the data collected at T0, T1 and T2 and then corrected for temperature and the amount of soil in each Kilner jar. Cumulative emissions were calculated by the sequential sum of the gas emitted at each data sample. In the end, total emissions of gaseous were converted into $\mathrm{CO}_{2}$ mass equivalent by global warming potential values of $265\left(\mathrm{~N}_{2} \mathrm{O}\right)$ and $28\left(\mathrm{CH}_{4}\right)$ based on a 100-year frame (IPPC, 2013).

Nitrogen mineralization experiment was performed using the same design and soil preparation as those used for GEE emissions measurement. In order to evaluate $\mathrm{N}$ mineral in soil, soil samples were collected using a plumb in Kilner jars. Collections were performed on days 0,3 , $7,10,14,17,21,28,35,49,63$ and 77 after the application. The residual net mineralization of nitrogen was calculated using the following formula:

$$
R N M=\left(\min N_{t=3,7, \ldots, 77}-\min N_{t=0}\right)-\min N_{C T R, t=3,7, \ldots, 77}
$$


After each collection, Kilner jars were weighed for the calculation of moist soil weight and moisture correction. The temperature of experiment was $25^{\circ} \mathrm{C}$.

\section{B.2.3. Analytical techniques}

All the analytical techniques used for soil characterization are fully described in Fangueiro et al., 2016.

Yeas waste characteristics were analysed according to the following methods: $\mathrm{pH}$ and EC were measured using a 1:10 $\mathrm{H}_{2} \mathrm{O}(\mathrm{v}: \mathrm{v})$ proportion after stiring to obtain a homogeneous material. Kjeldhal method (Horneck \& Miller, 1998) was used to determine total N. N mineral was determined by distillation with the addiction of ferric sulphate and silver sulphate. The dry combustion method was used for the dry matter determination. TOC was determined in a Primacs TOC analyser as described in Fangueiro et al., 2016. Total $P$ was determined by the Vanado Molybdate method using a spectrophotometer. Ash content was extract using chloridric acid in order to determine other macro and microelements by atomic absorption spectrophotometry.

\section{B.2.4. Statistical analyses}

One-way ANOVA was performed to study the variance of each treatment and, for temporal analysis, two-way ANOVA was used according to the respective experimental design ( $\mathrm{x}$ treatments $\times$ y replicates). Tukey test was used for means comparison at a probability level of 0.05 and to calculate the standard error on each day. The level of statistical significance was $p<0.05$ to a different mean values and $p<0.01$ to a significant difference. The statistical software used was Statistix. 
C. Results

\section{C.1. Short-term experiment}

As can be seen in Figure 9, yeast application to soil increased leachate $\mathrm{pH}$ from 4-4.5 to $\approx 7$, in the second irrigation event, and it tends to decrease slowly after that $(p<0.05)$. An increase of $\mathrm{pH}$ value was also observed in the control treatment with from 5.05 to 5.94. Yeast increased $E C$ in the first IE but overall EC values were not different between treatments $(p>0.05)$ (Figure 10).

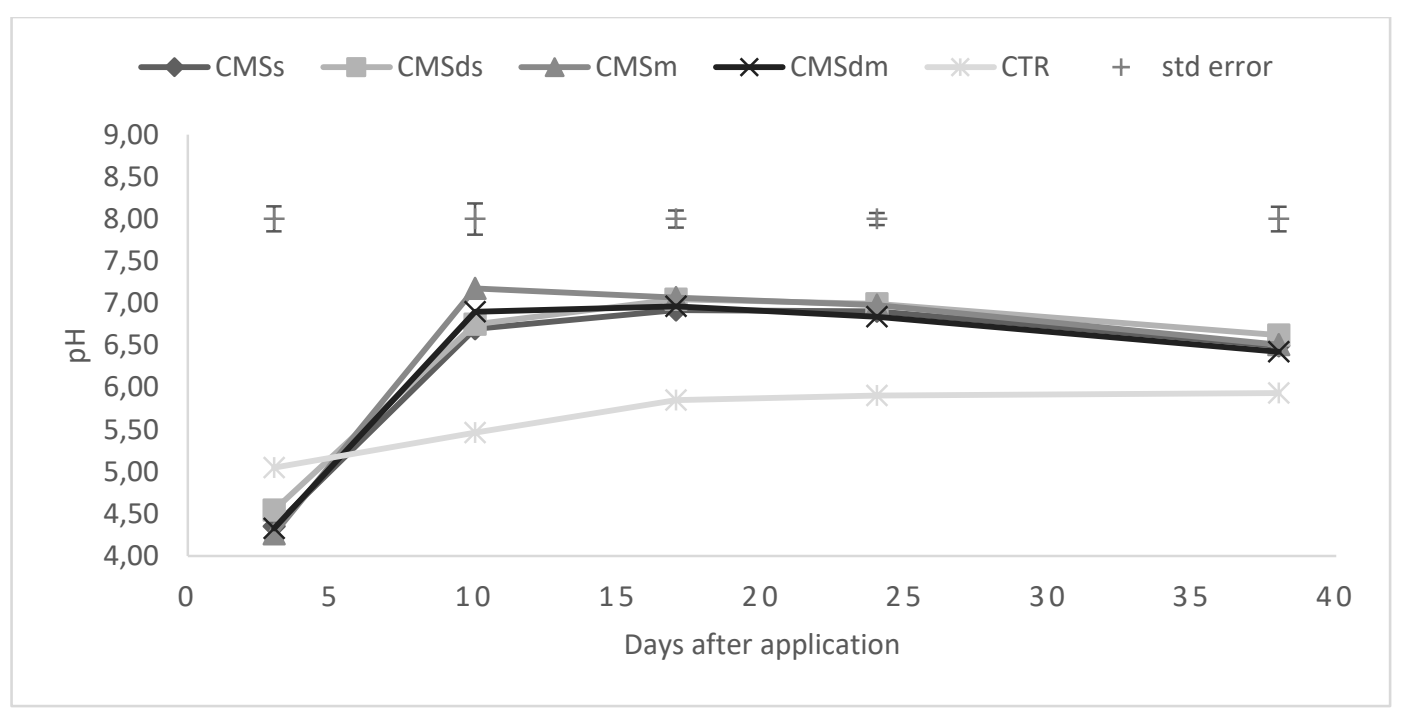

Figure A1 - pH of leachates observed during the 5 irrigation events performed in the short-term experiment (38day period). Means of 6 replicates. Error bars represent the standard error used on each leaching event to assess significant $(P<0.05)$ differences between mean values. 


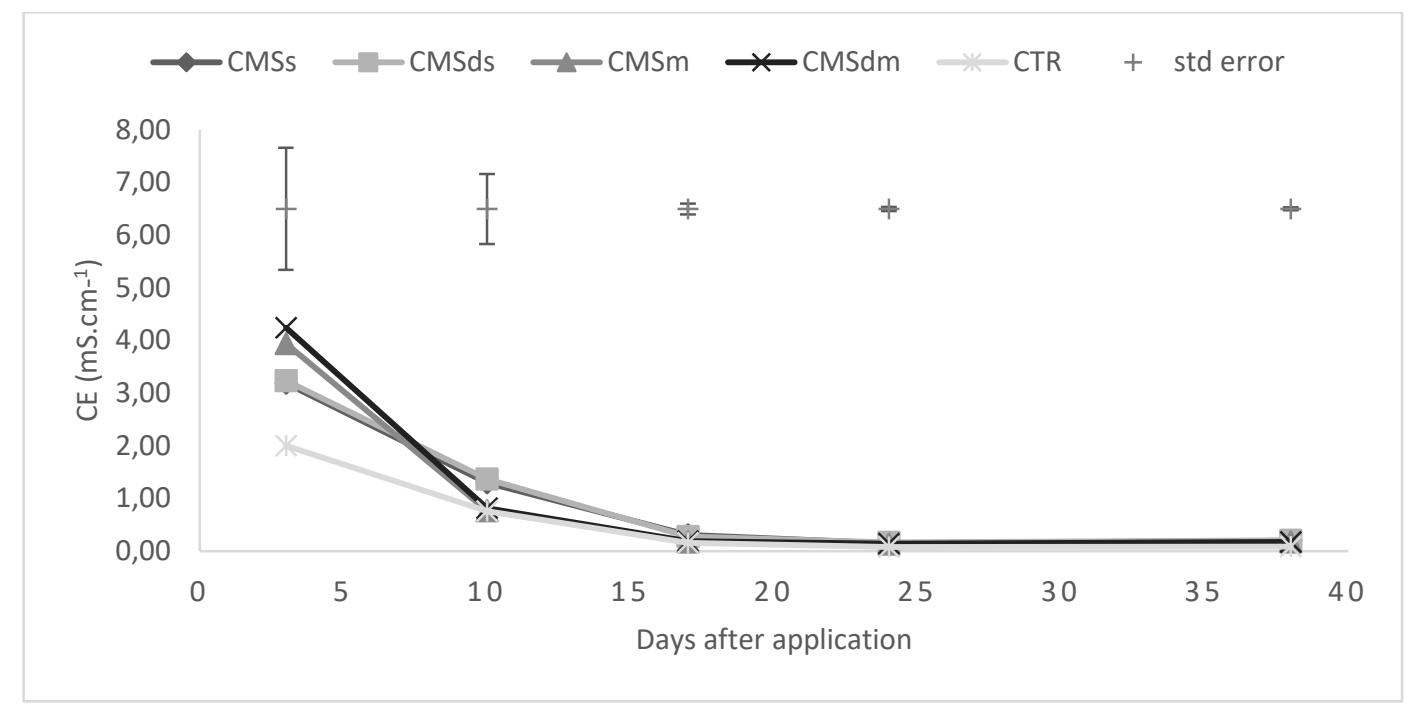

Figure A2 - EC of leachates observed during the 5 irrigation events performed in the short-term experiment (38day period). Means of 6 replicates. Error bars represent the standard error used on each leaching event to assess significant $(P<0.05)$ differences between mean values.

Amounts of ammonium leached in yeast treatments in the first IE were around 0.53 to $0.94 \mathrm{mg}$ more than control ( $p>0.05)$ (Figure 13). However, in the second IE there was a large increase in CMSm and CMSdm treatments whereas similar values where observed $(p<0.05)$ between CMSs and CMSds and control. Surface application of CMS and CMSd led to a later ammonium leaching observed in the third and four IEs $(p<0.05)$. 38 days after application, residual values of $\mathrm{NH}_{4}{ }^{+}-\mathrm{N}$ were observed in leachates.

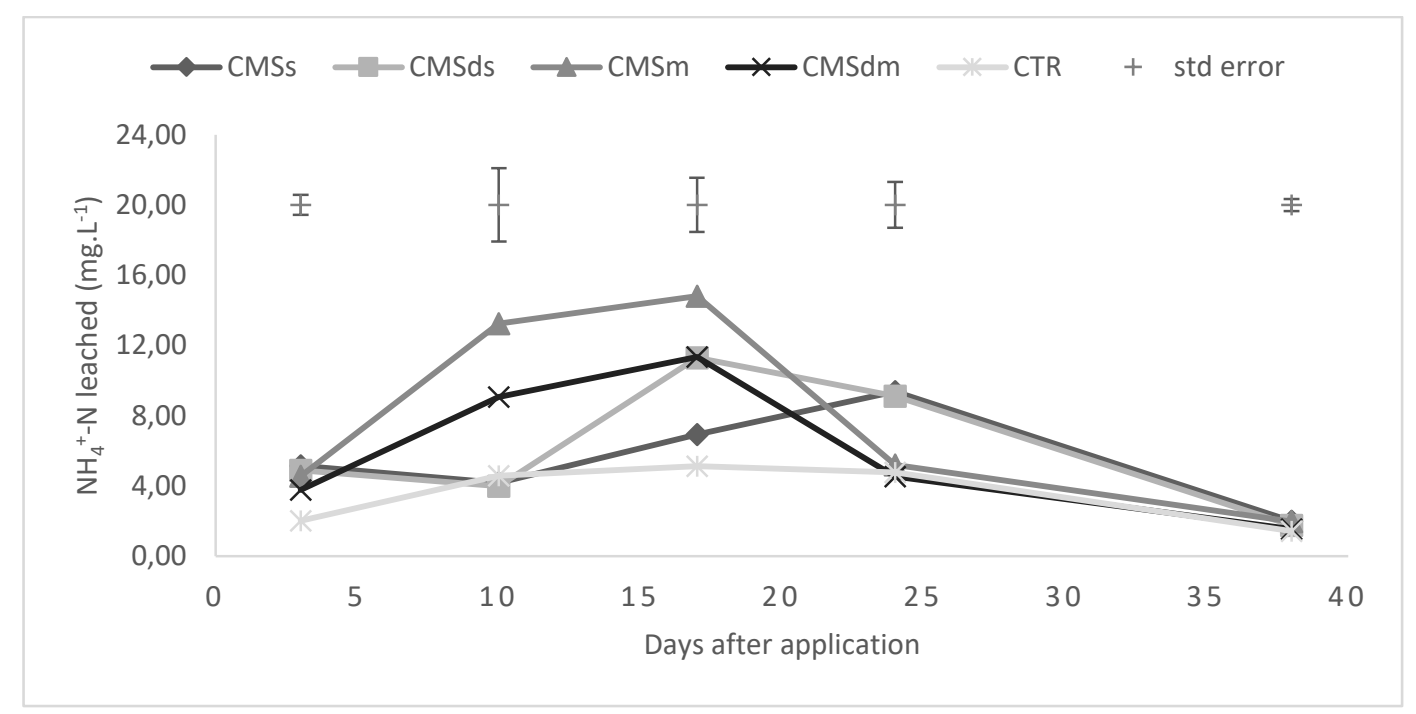

Figure A3 - Ammonium concentration of leachates observed during the 5 irrigation events performed in the shortterm experiment (38-day period). Means of 6 replicates. Error bars represent the standard error used on each leaching event to assess significant $(P<0.05)$ differences between mean values. 
Nitrate content in the soil used here was so high (Table 1) that led to an initial leaching of 75.8 $\mathrm{mg} \mathrm{NO}_{3}-\mathrm{N}$ in the control and values in all yeast treatments except CMSm were lower $(\mathrm{p}<0.05)$ than in control in the first IE (Figure 14). In the second IE, a significant $(p<0.05)$ decrease of nitrate leached was observed with the CMSm and CMSdm treatments. After that, almost all nitrate contained in soil was leached therefore similar $(p>0.05)$ values between treatments were observed thereafter.

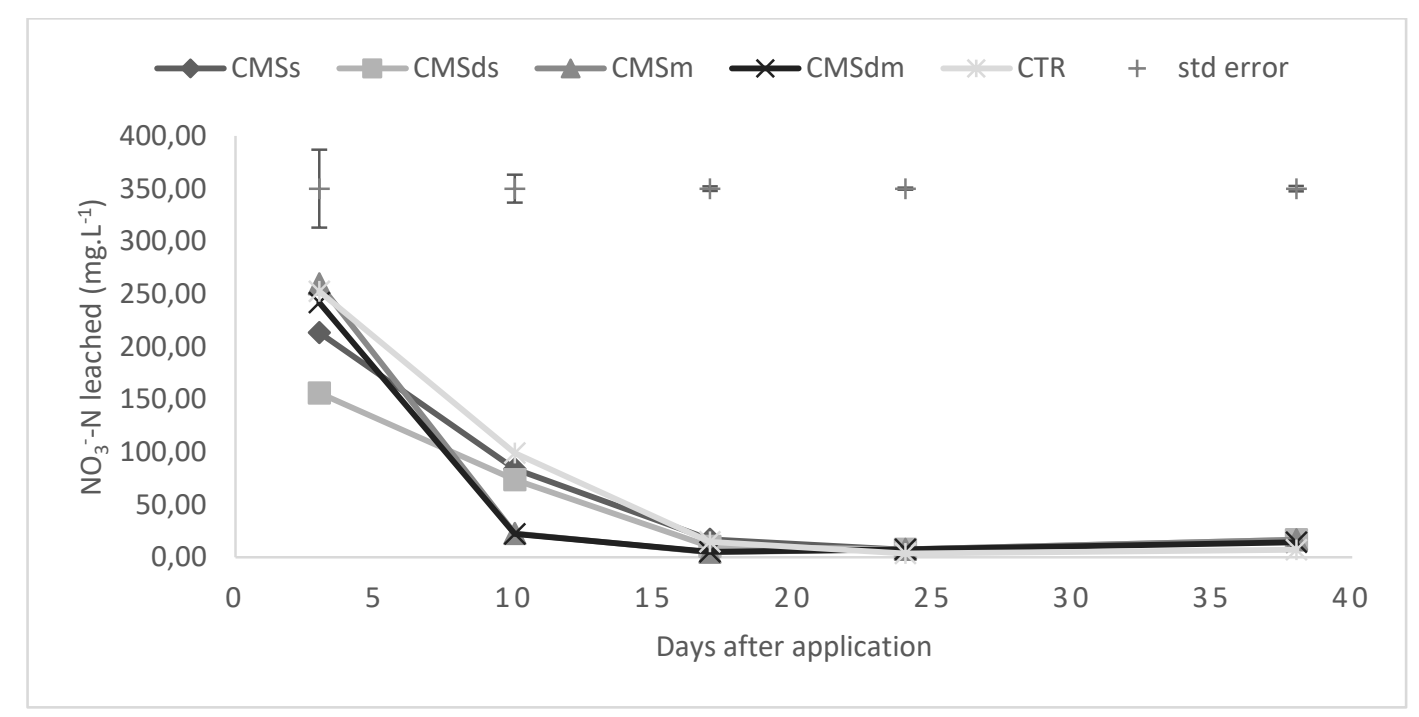

Figure A4 - Nitrate concentration of leachates observed during the 5 irrigation events performed in the short-term experiment (38-day period). Means of 6 replicates. Error bars represent the standard error used on each leaching event to assess significant $(P<0.05)$ differences between mean values.

Phosphorus losses by leaching were different in each treatment during the experiment $(p<0.05)$ (Figure 15). Differences between surface applied treatments and treatments including soil incorporation were similar to the pattern observed for ammonium losses. CMS and CMSd provided around 1.18 and $2.38 \mathrm{mg}$ of total phosphorus in soil and total $\mathrm{P}$ leached values were similar. Temporal analysis showed a difference between the five IE in terms of $P$ content of leachates $(p<0.05)$. 


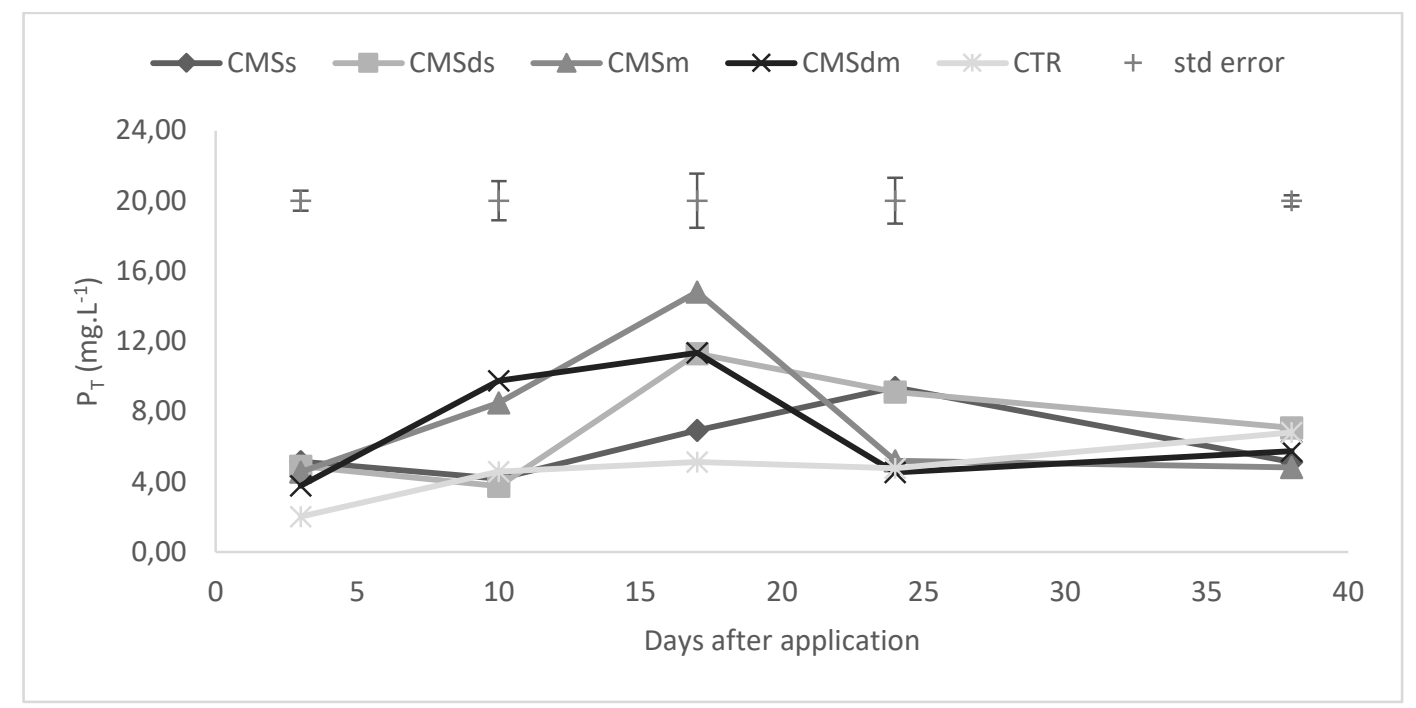

Figure A5 - Phosphorus concentration of leachates observed during the 5 irrigation events performed in the shortterm experiment (38-day period). Means of 6 replicates. Error bars represent the standard error used on each leaching event to assess significant $(P<0.05)$ differences between mean values.

The variation of potassium losses between treatments during all IEs except IE 3 was significant $(p<0.05)$ (Figure 16). Whereas $\mathrm{K}$ losses from CMSds increased significantly (182 $\mathrm{mg} \mathrm{K}^{-\mathrm{L}^{-1}}$ ) in the second IE, the opposite was observed with CMSm. Even in the two last IE, yeast waste continued to leach more potassium relative to control due high $\mathrm{K}$ applications (65 and $137 \mathrm{mg}$ $\mathrm{K}, \mathrm{CMS}$ and CMSd respectively) that were not totally leached but in CMSs treatment. Decanted yeast application led to $\mathrm{K}$ losses $\approx 25 \%$ higher than non-decanted yeast, and this value increased $5 \%$ with the surface application. Decanted CMS led to a higher values of total potassium retained in soil ( 24.1 and $46.6 \%$, surface and incorporation treatment). Temporal analysis showed significant difference $(p<0.01)$ between $K$ losses obtained in the five IE and ANOVA indicated a significant interaction between time and treatments. 


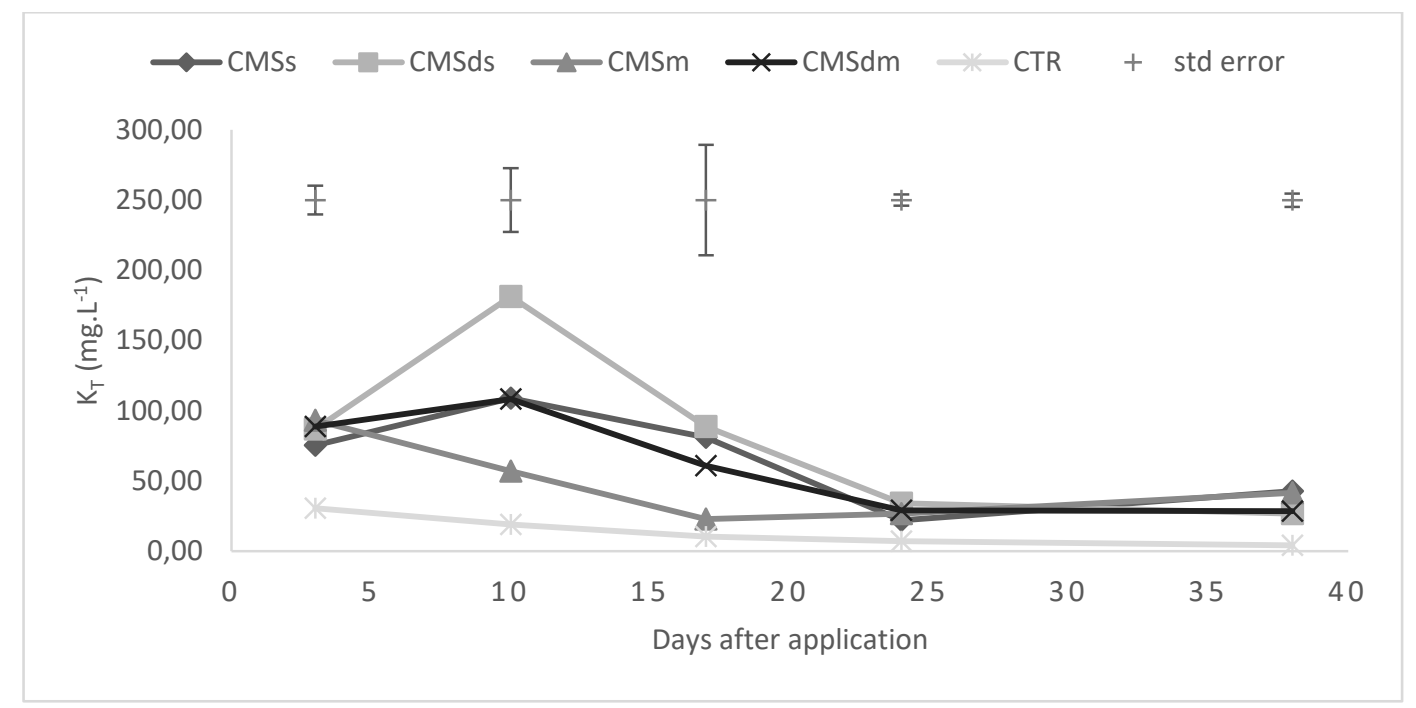

Figure A6 - Potassium concentration of leachates observed during the 5 irrigation events performed in the shortterm experiment (38-day period). Means of 6 replicates. Error bars represent the standard error used on each leaching event to assess significant $(P<0.05)$ differences between mean values.

At the end of the leaching experiment, soil columns were divided in 4 depth samples (0-6, 6$12,12-18,18-24 \mathrm{~cm})$. All treatments except CMSs led to a final soil $\mathrm{pH}$ values lower than 6.5 , and were significantly different from control $(\mathrm{p}<0.01)$ (Figure 17). No significant differences in terms of EC were observed between treatments $(p<0.05)$ due high weekly application of deionized water (Figure 18).

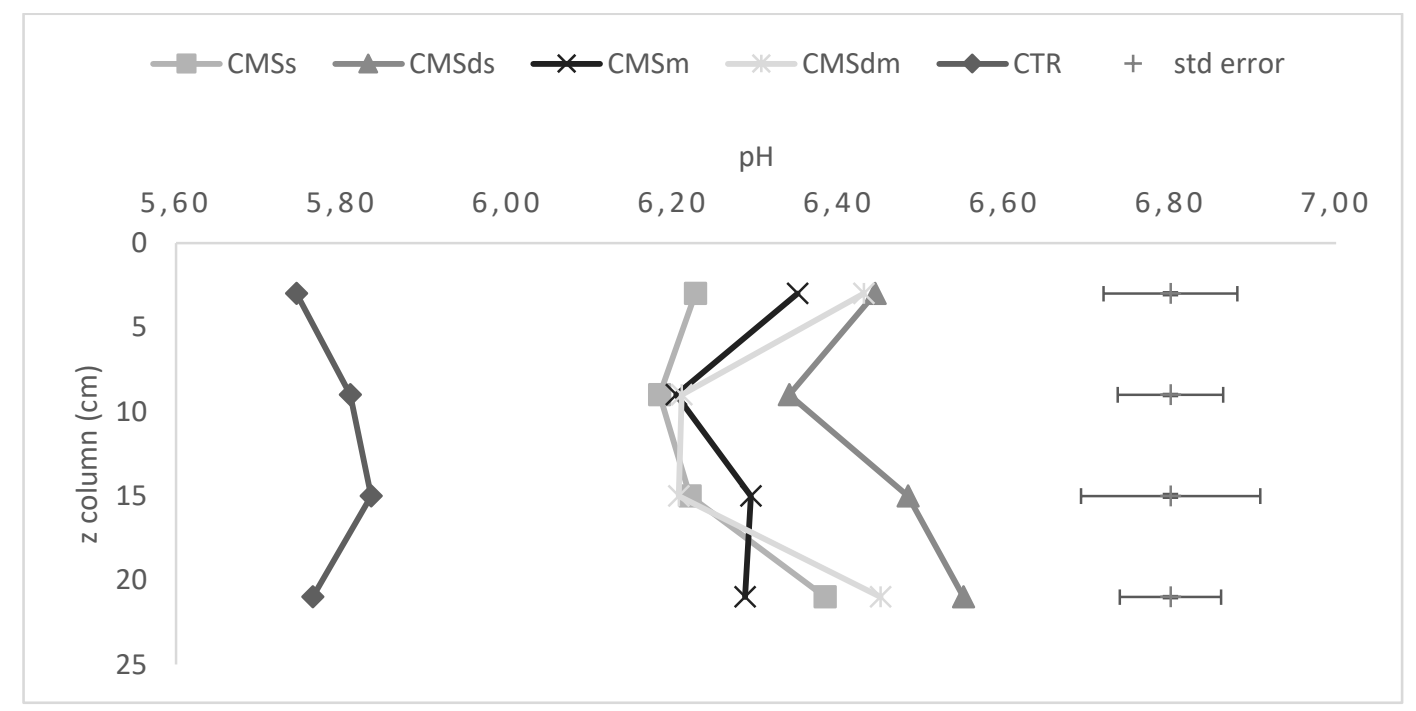

Figure A7 - Variation of the $\mathrm{pH}$ along the soil columns at the end of the short-term experiment. Means of 3 replicates. Error bars represent the standard error used on each leaching event to assess significant $(P<0.05)$ differences between mean values. 


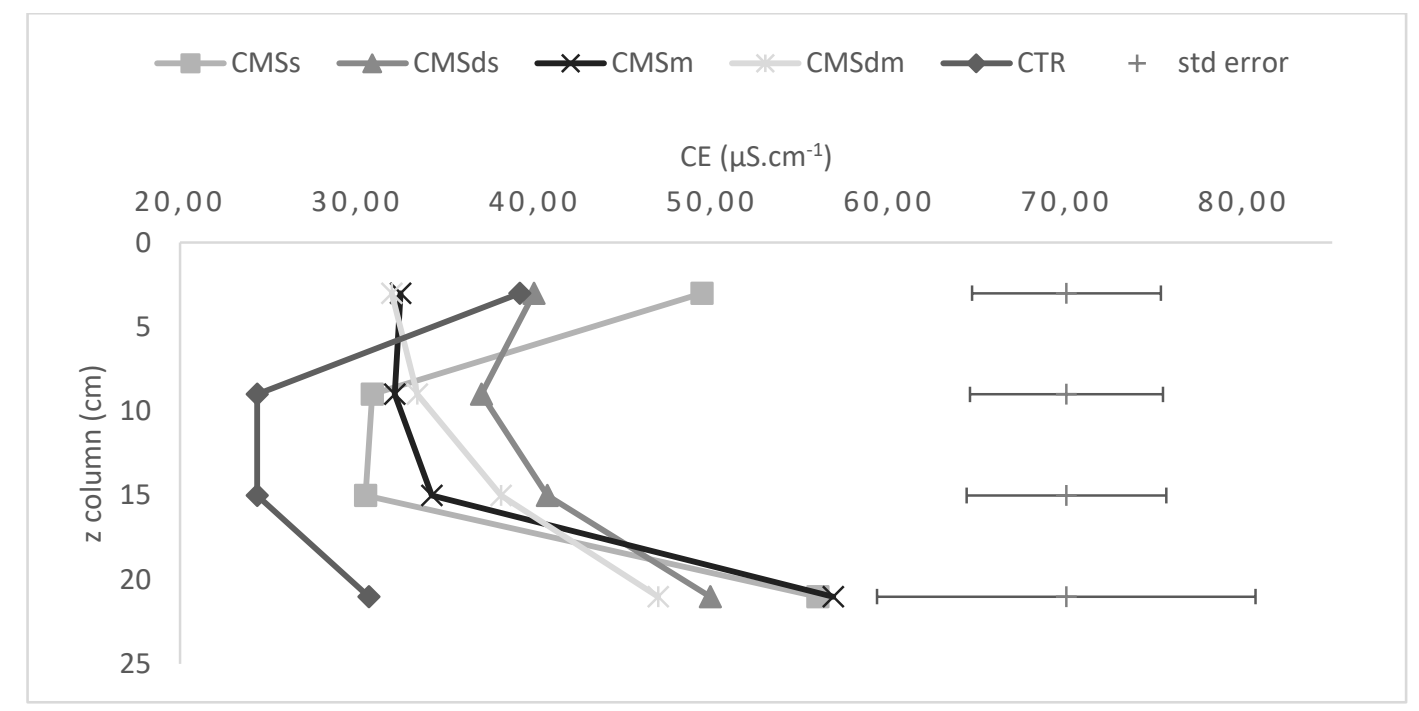

Figure A8 - Variation of the EC along the soil columns at the end of the short-term experiment. Means of 3 replicates. Error bars represent the standard error used on each leaching event to assess significant $(P<0.05)$ differences between mean values.

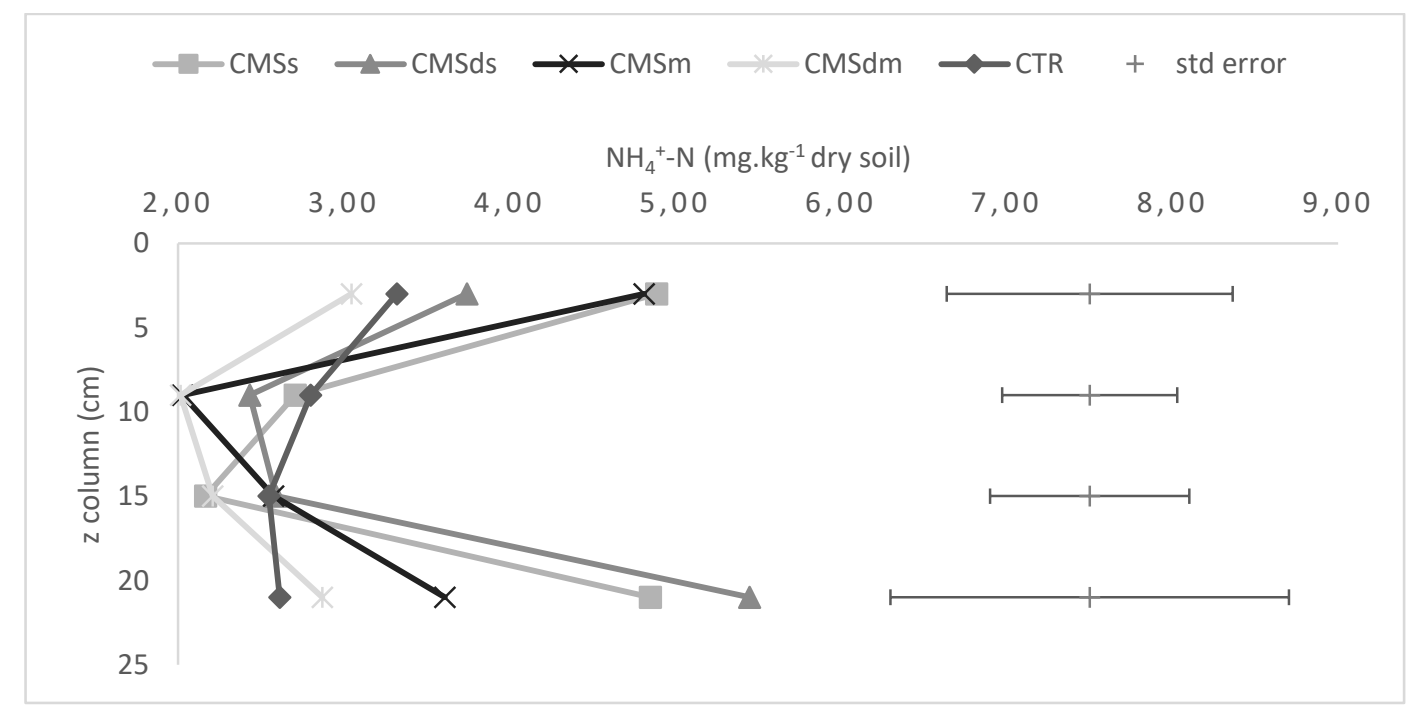

Figure A9 - Variation of the ammonium content along the soil column at the end of the short-term experiment. Means of 3 replicates. Error bars represent the standard error used on each leaching event to assess significant $(P<0.05)$ differences between mean values. 


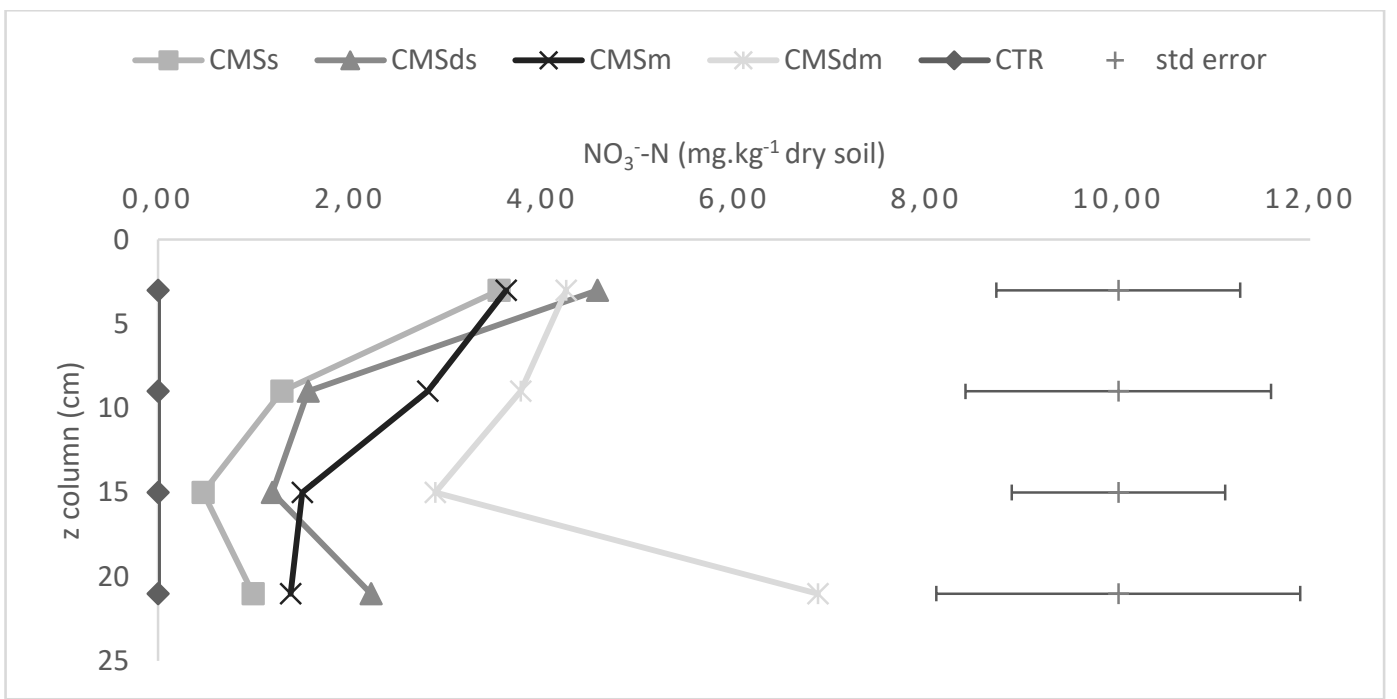

Figure A10 - Variation of the nitrate content along the soil column at the end of the short-term experiment. Means of 3 replicates. Error bars represent the standard error used on each leaching event to assess significant $(P<0.05)$ differences between mean values. 


\section{C.2. Long-term experiment}

\section{C.2.1. Long-term leaching experiment}

$\mathrm{pH}$ values observed in control at the first IE were significantly higher than in all other treatments (Figure 21). In the second IE there was a significant increase of $\mathrm{pH}$ values in yeast treatments, higher in CMSs and CMSds, whereas the opposite was found with the application of ammonium nitrate. On all remaining IE except the last one, $\mathrm{pH}$ values between treatments were significantly different results between from each other $(p<0.05)$.

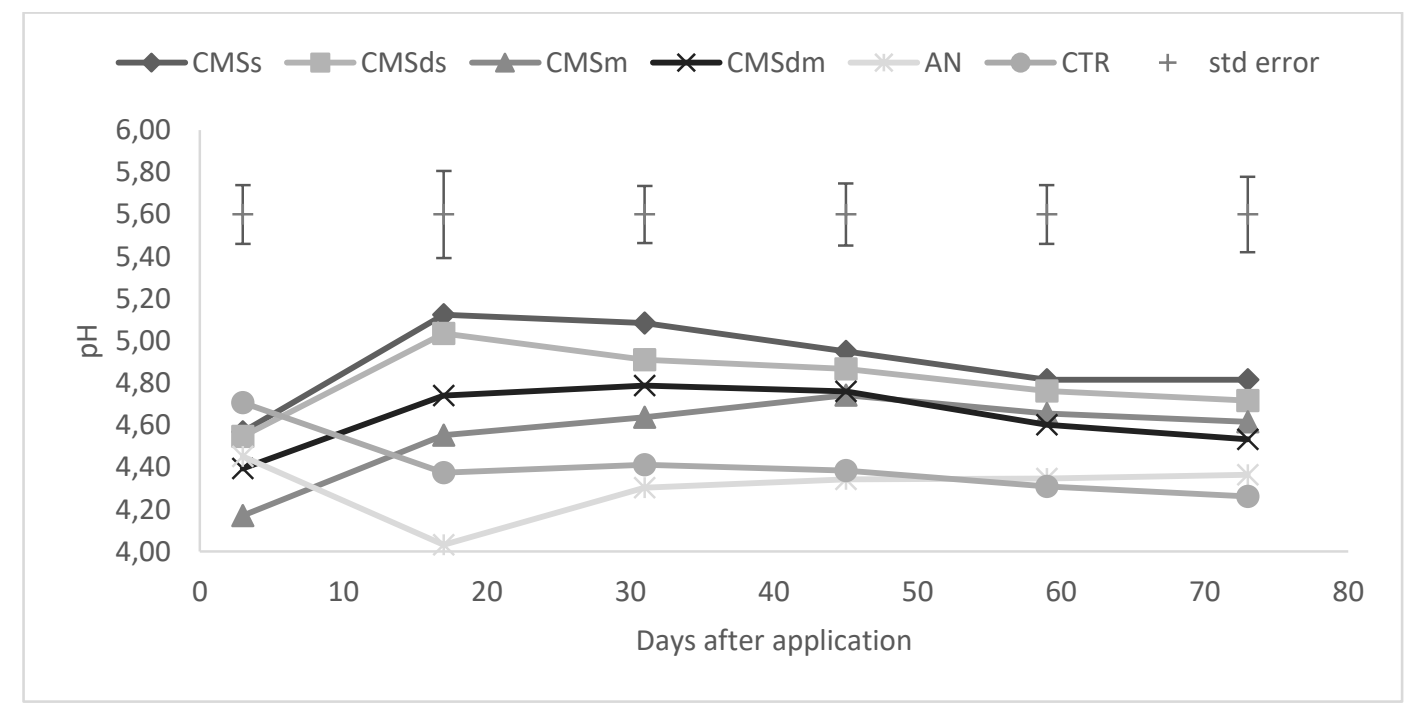

Figure A11 - $\mathrm{pH}$ of leachates observed during the 6 irrigation events performed in the long-term experiment (73day period). Means of 4 replicates. Error bars represent the standard error used on each leaching event to assess significant $(P<0.05)$ differences between mean values.

Yeast waste application to soil increased significantly the EC values in leachates but these values decreased significantly to reach control values at the third IE (Figure 22). An increase of EC values of leachates was also observed with AN application but such increased was not so significant. 


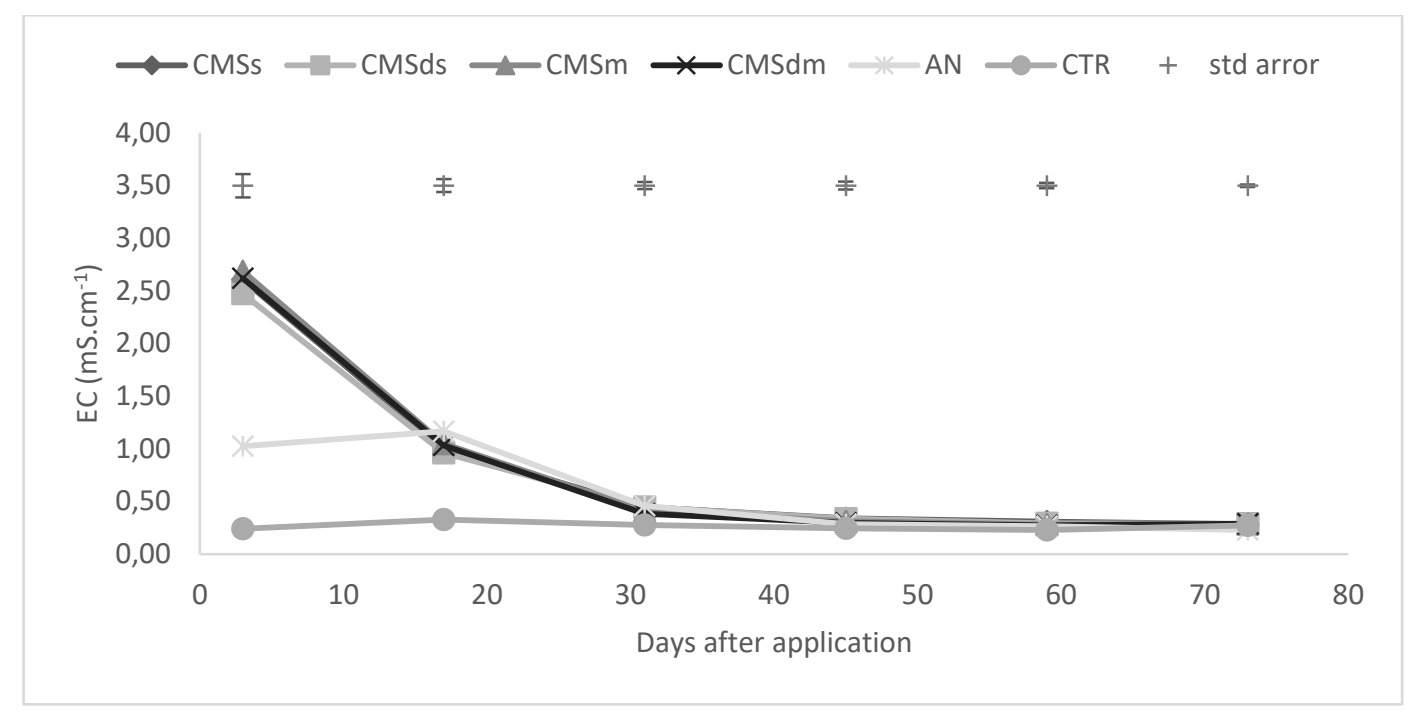

Figure A12 - EC of leachates observed during the 6 irrigation events performed in the long-term experiment (73day period). Means of 4 replicates. Error bars represent the standard error used on each leaching event to assess significant $(P<0.05)$ differences between mean values.

Significant differences $(p<0.05)$ between treatments in terms of content of leachates were observed only at the first IE (Figure 23). In the first IE, around $16 \mathrm{mg} \cdot \mathrm{L}-1$ (9.5\% of total ammonium applied) was leached with AN application, and yeast led to values between 5-10 $\mathrm{mg} \cdot \mathrm{L}^{-1}$. In the second IE a marked decrease of $\mathrm{NH}_{4}{ }^{+}-\mathrm{N}$ leached in AN treatment was observed. From the third IE onwards, values of ammonium leached were very similar between treatments $(p>0.05)$. 


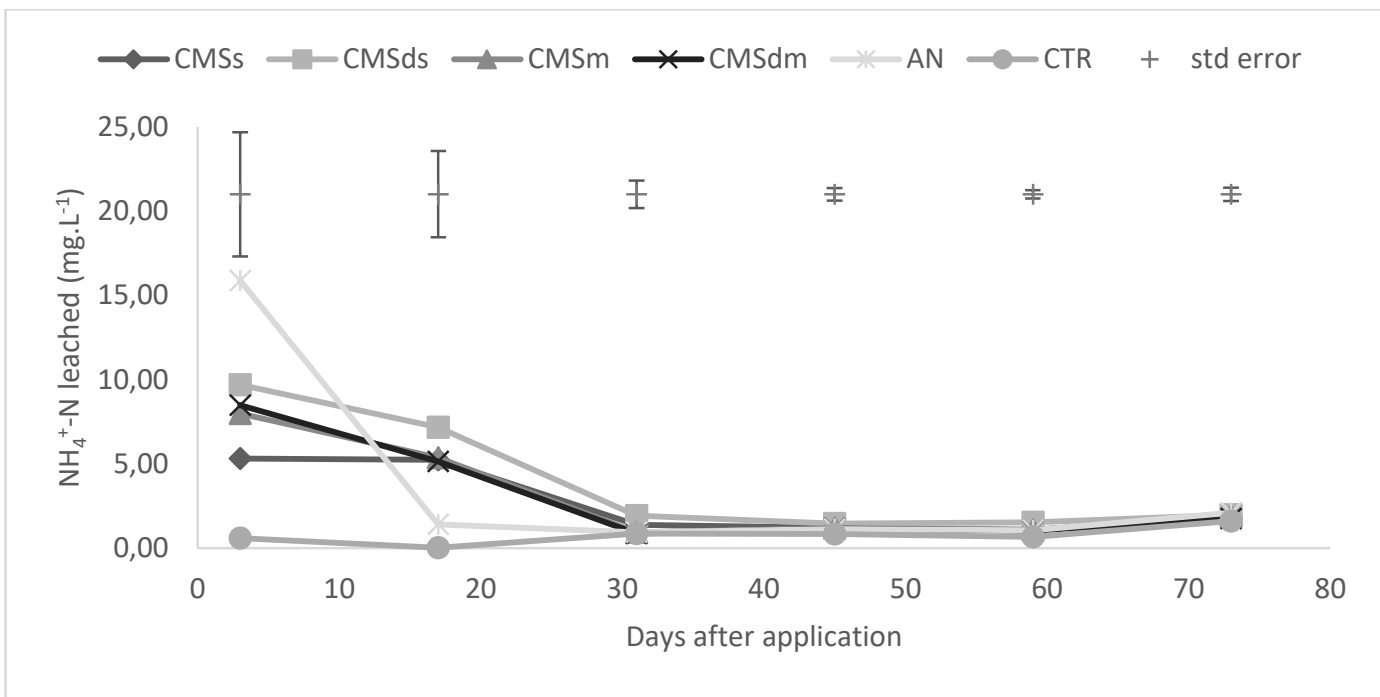

Figure A13 - Ammonium concentration of leachates observed during the 6 irrigation events performed in the longterm experiment (73-day period). Means of 4 replicates. Error bars represent the standard error used on each leaching event to assess significant $(P<0.05)$ differences between mean values.

Nitrate leached in yeast treatments and control were very similar in the first IE whereas the application of $\mathrm{AN}$ led to leaching of $85 \mathrm{mg} \mathrm{NO}_{3}{ }^{-} \mathrm{N} \cdot \mathrm{L}^{-1}$ significantly more than control $(\mathrm{p}<0.05)$ (Figure 24). Nitrate applied by $\mathrm{AN}$ application was $21 \mathrm{mg} \mathrm{NO}_{3}-\mathrm{N}$, and about 13.4 and $25.3 \mathrm{mg}$ of nitrate were leached by AN application in the two first IEs. Yeast waste led to a largest increase of nitrate leaching in the second IE with values between 51 and $65 \mathrm{mg} \mathrm{NO}_{3}{ }^{-} \mathrm{N} \cdot \mathrm{L}^{-1}$ $(p<0.05)$. Furthermore, surface application led to lower nitrate losses relative to CMSm and CMSdm. After three IE, nitrate leaching was similar $(p<0.05)$ in all treatments including control. 


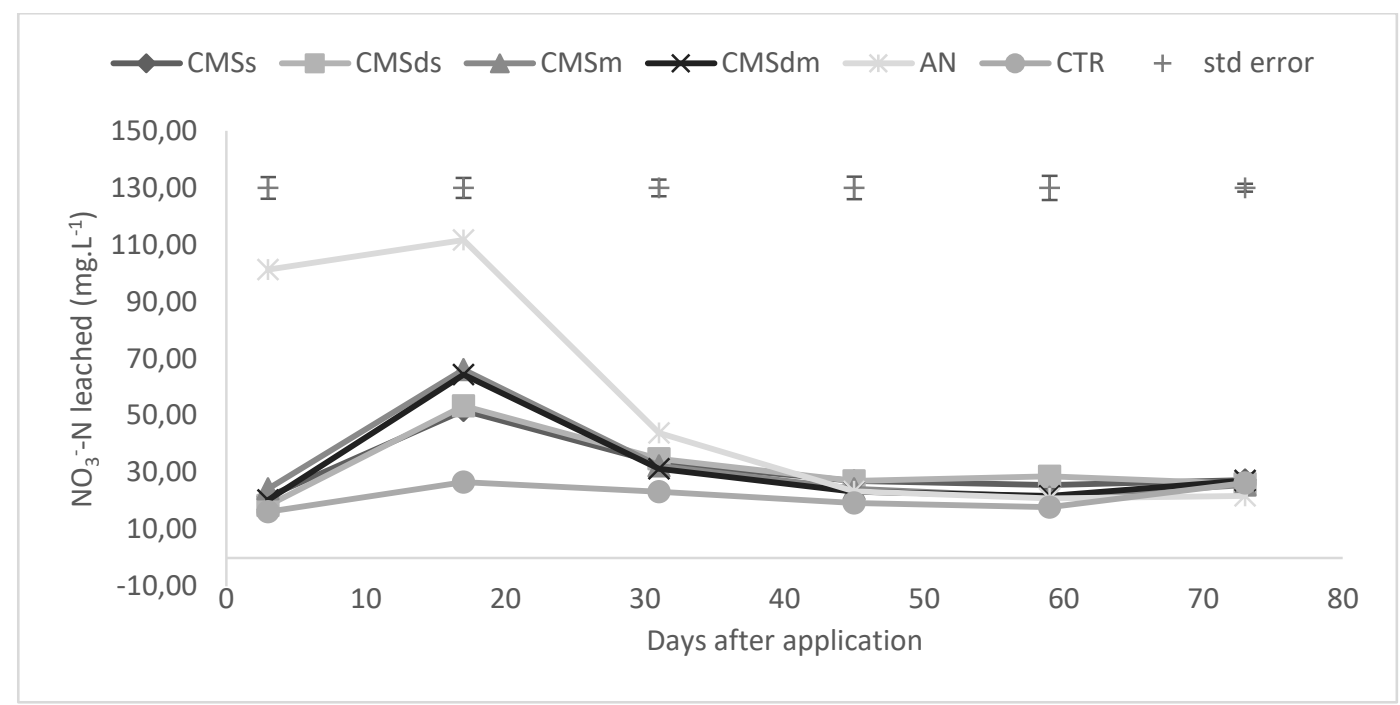

Figure A14 - Nitrate concentration of leachates observed during the 6 irrigation events performed in the long-term leaching (73-day period). Means of 4 replicates. Error bars represent the standard error used on each leaching event to assess significant $(P<0.05)$ differences between mean values.

Phosphorus leached, in all treatments, had similar values $(p>0.05)$ and tend to follow the same behaviour during the six IE (Figure 25). In the third and fourth IE, an increase of $P$ leaching was observed in CMSd treatment. Total $P$ leached values were between 6.1 and $9.2 \mathrm{mg} P$ and the highest was observed with the mix application of CMSd.

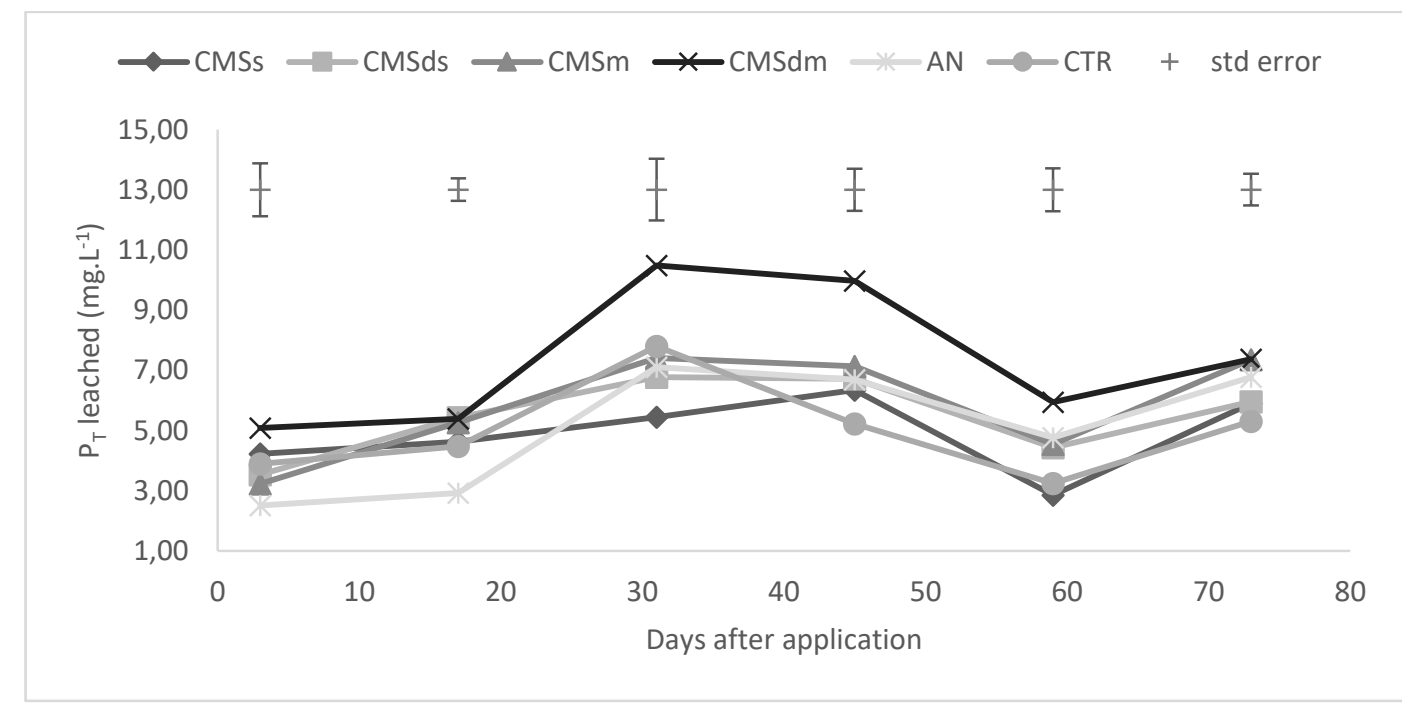

Figure A15 - Phosphorus concentration of leachates observed during the 6 irrigation events performed in the long-term leaching (73-day period). Means of 4 replicates. Error bars represent the standard error used on each leaching event to assess significant $(P<0.05)$ differences between mean values. 


\section{C.2.2. Nitrogen mineralization experiment}

Compared to control, yeast waste application increased $\mathrm{pH}$ from 5.5 to 7 on day 0 , immediately after the application (Figure 26). On day 3 surface application of yeast led to an increase of $\mathrm{pH}$ in soils. $\mathrm{pH}$ values between treatments were significantly different until day $17(\mathrm{p}<0.01)$. Over time, $\mathrm{pH}$ of soil amended with yeast tended to be similar to control. On the other hand, soil $\mathrm{pH}$ in AN treatment decreased significantly along the experiment. The differences between EC soil values in yeast, AN and CTR treatments were almost constant, with results significantly different from each other $(p<0.01)$ (Figure 25). While the EC values in control remained low, yeast waste application increased significantly soil EC with higher values than in AN applied soil.

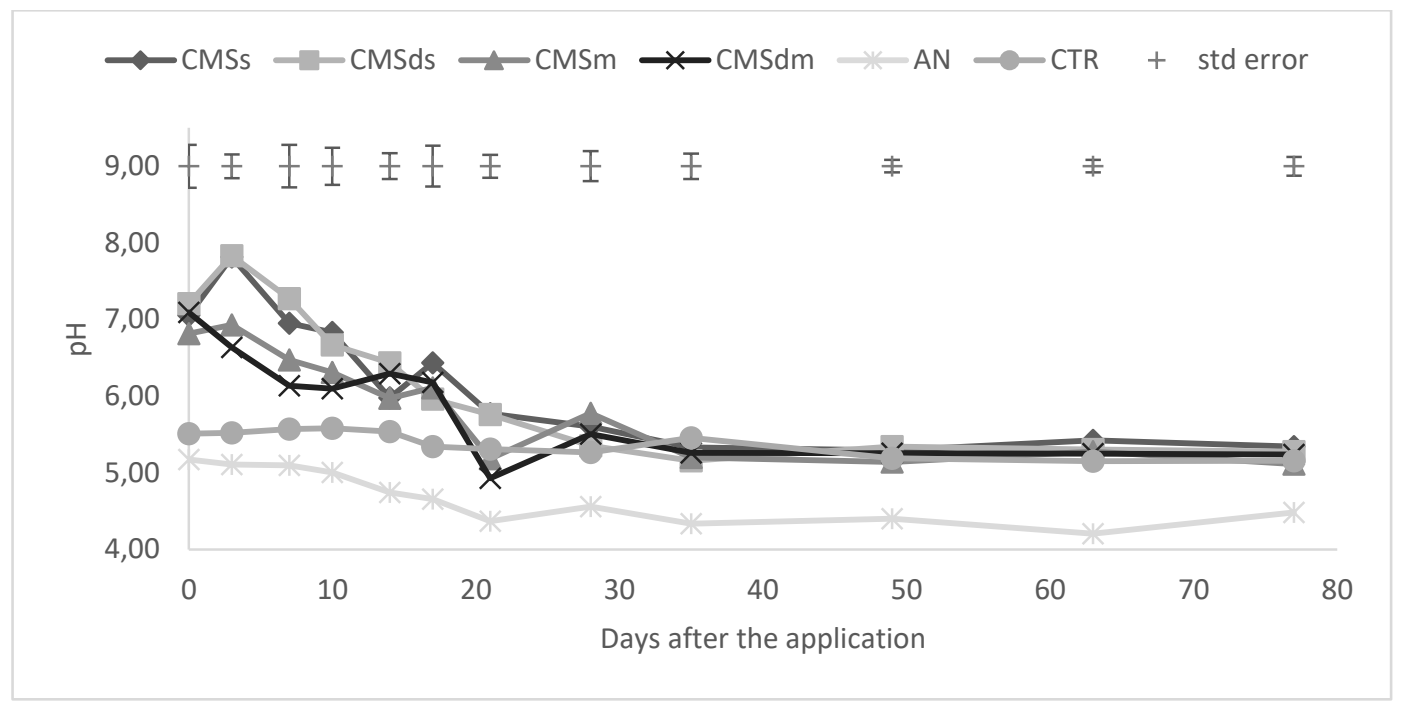

Figure A16 - Evolution of soil pH during the long-term experiment (77-day period). Means of 3 replicates. Error bars represent the standard error used on each leaching event to assess significant $(P<0.05)$ differences between mean values. 


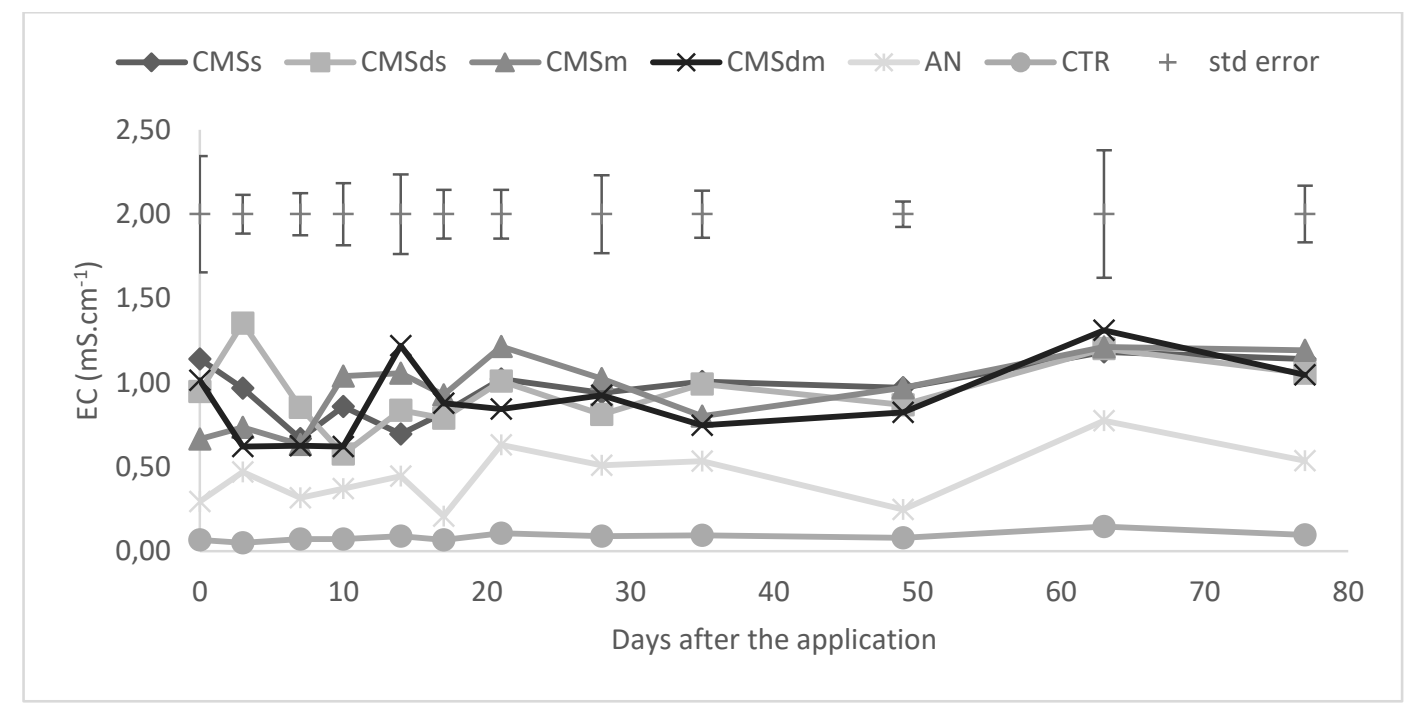

Figure A17 - Evolution of soil EC during the long-term experiment (77-day period). Means of 3 replicates. Error bars represent the standard error used on each leaching event to assess significant $(P<0.05)$ differences between mean values.

Initially, values of $\mathrm{NH}_{4}{ }^{+}-\mathrm{N}$ contents in soil from yeast and control treatments were very similar $(p<0.05)$ whereas the AN application provided an immediately high amount of ammonium available in soil (around $51.5 \mathrm{mg} . \mathrm{kg}^{-1}$ dry soil) (Figure 28). On day three a significant increase was observed in yeast treatments (higher in surface application). From day 28 onwards, ammonium was almost completely leached and values of soil in all treatments were very similar $(p<0.05)$. The decrease of $\mathrm{NH}_{4}{ }^{+}-\mathrm{N}$ content in soil in $\mathrm{AN}$ treatment was led pronounced here than in the leaching experiment. 


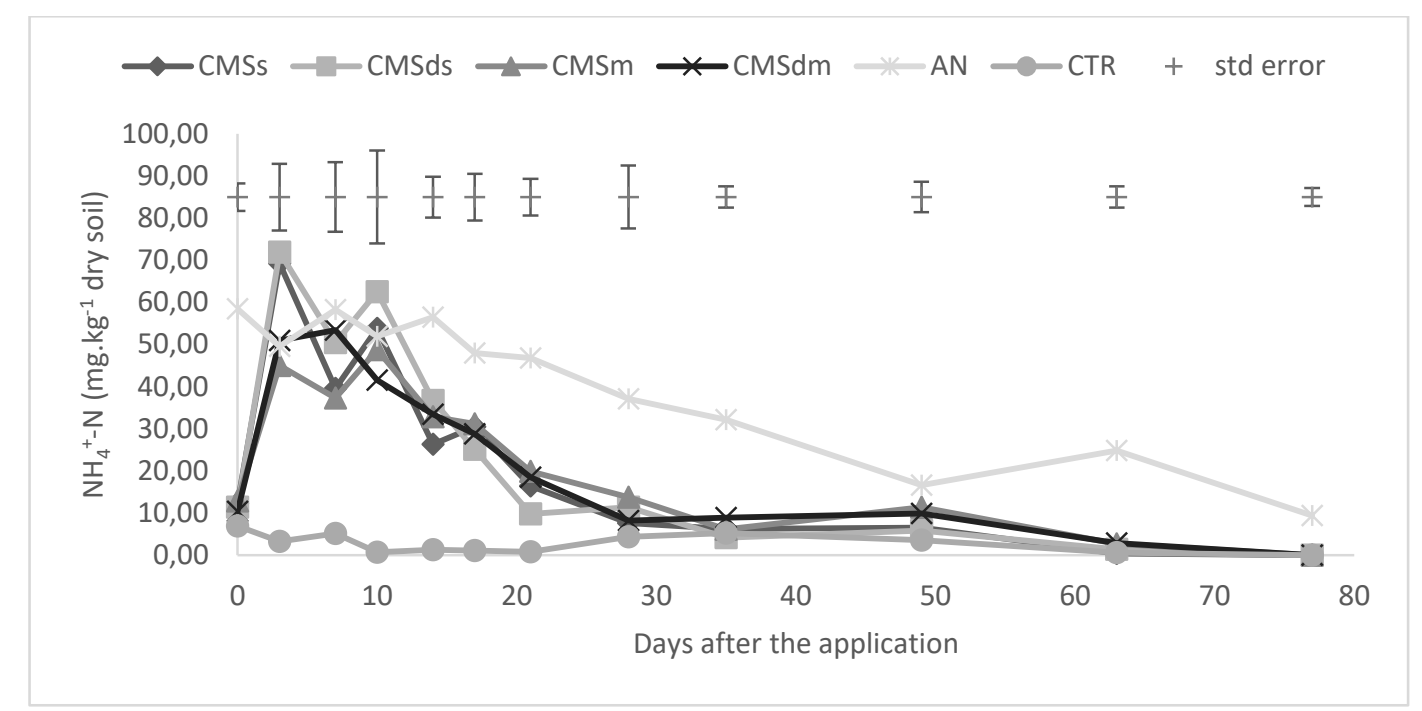

Figure A18 - Evolution of soil ammonium content during the long-term experiment (77-day period). Means of 3 replicates. Error bars represent the standard error used on each leaching event to assess significant $(P<0.05)$ differences between mean values.

On day zero, there was a slight increase of nitrate content with yeast application whereas the amount of nitrate provided by AN application was approximately $68 \mathrm{mg} \mathrm{NO}_{3}^{-}-\mathrm{N}^{-\mathrm{kg}^{-1}}$ of dry soil (17.75 mg less than expected), which was a very significant value comparison to other treatments $(p<0.01)$ (Figure 29). Nitrate content in yeast treatments decreased on day 3 followed by an increase until the end of experiment, where values were not different compared to AN treatment ( $p>0.05)$. Comparing with initial values, CMSm and CMSdm treatments had a higher increase of nitrate content (123 and $14368 \mathrm{mg} \mathrm{NO}_{3}^{-}-\mathrm{N}^{-\mathrm{kg}^{-1}}$ of dry soil, CMSm and CMSdm respectively). Control remained below with a low increase of nitrate content in soil (6.8 to $29.8 \mathrm{mg} \mathrm{NO}_{3}^{-}-\mathrm{N}^{-\mathrm{kg}^{-1}}$ of dry soil). 


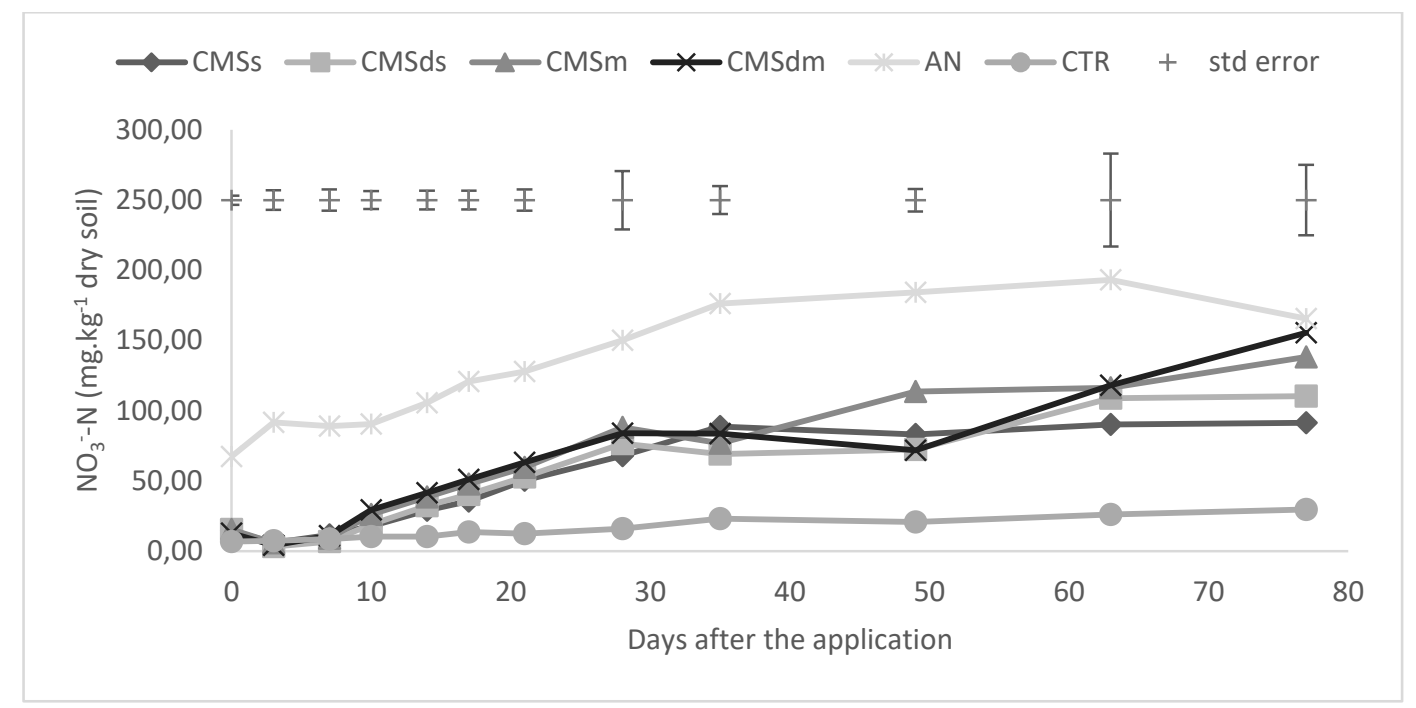

Figure A19 - Evolution of soil nitrate content during the long-term experiment (77-day period). Means of 3 replicates. Error bars represent the standard error used on each leaching event to assess significant $(P<0.05)$ differences between mean values.

A positive residual net mineralization (RNM) was observed in all application treatments along the experiment (Figure 30), since ammonium concentrations increased on first days and nitrate concentrations later. At the end, RNM varied significantly between treatments but higher values in treatments with yeast application.

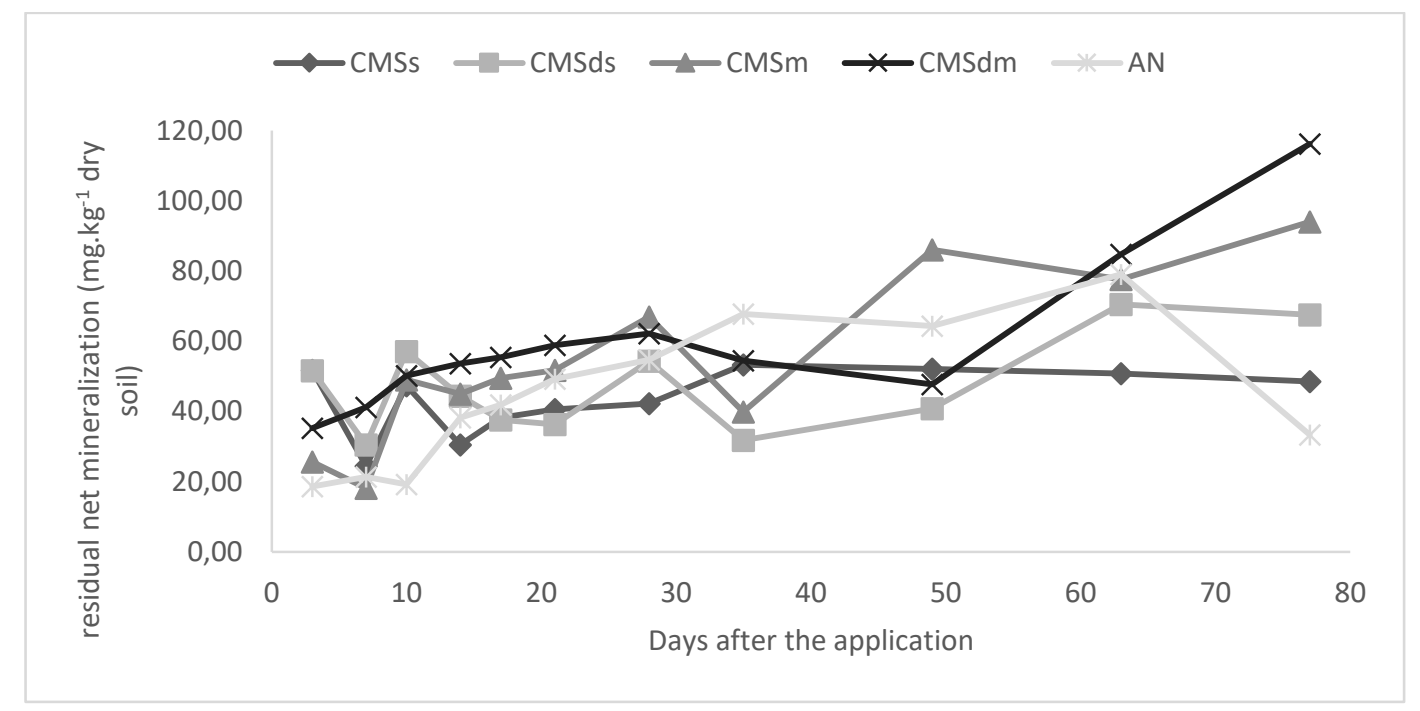

Figure A20 - Evolution of soil Net nitrogen mineralization during the long-term experiment (77-day period). 


\section{C.2.3. GHG emissions experiment}

\section{$\mathrm{N}_{2} \mathrm{O}$ emissions}

A significant difference between treatments relative to $\mathrm{N}_{2} \mathrm{O}$ emissions was observed on initial days $\left(0-6\right.$ days) $(p<0.01)$ with a large increase of $\mathrm{N}_{2} \mathrm{O}$ emissions in yeast treatments while the AN treatment had only a slight increase on day 1 with a maximum value of $166 \mathrm{ug} \mathrm{N} \mathrm{N}_{2} \mathrm{O}-\mathrm{N} . \mathrm{kg}^{-1}$ dry soil (Figure 31 and 32). Yeast treatments results showed that the increase was fastest in CMSm and CMSdm treatments where 71.7 and 65.6\% (CMSm and CMSdm) of $\mathrm{N}_{2} \mathrm{O}$ were emitted on first two days. On the other hand, CMSs and CMSds treatments had higher values on day one, 64.6 and $54.4 \%$ (CMSs and CMSds) of $\mathrm{N}_{2} \mathrm{O}$. Between days 3 and 36 , a lot of variations were observed a lot of variations, especially in yeast treatments, where values had some oscillations. After that, there was no difference between treatments ( $p>0.05)$, and values tend to be almost null.

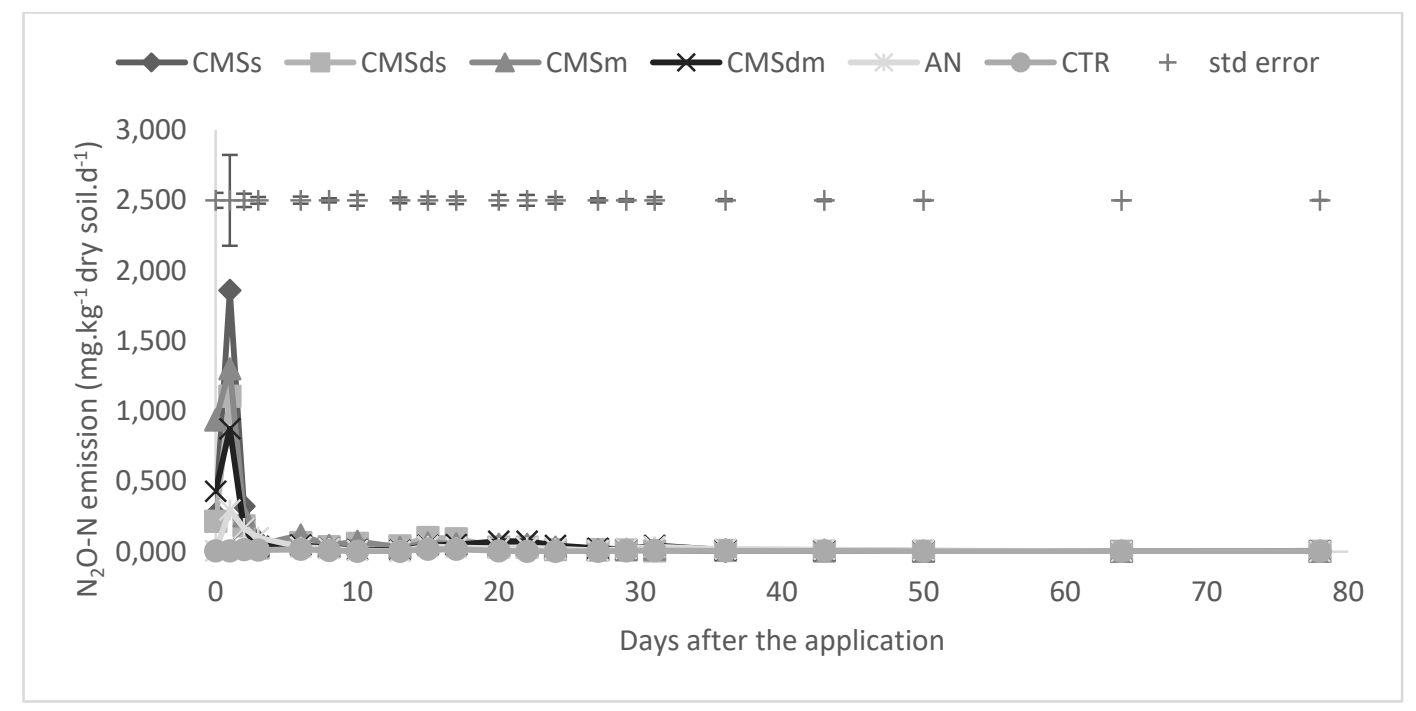

Figure A21 - $\mathrm{N}_{2} \mathrm{O}-\mathrm{N}$ emissions evolution during the long-term experiment (78-day period). Means of 3 replicates. Error bars represent the standard error used on each leaching event to assess significant $(P<0.05)$ differences between mean values. 


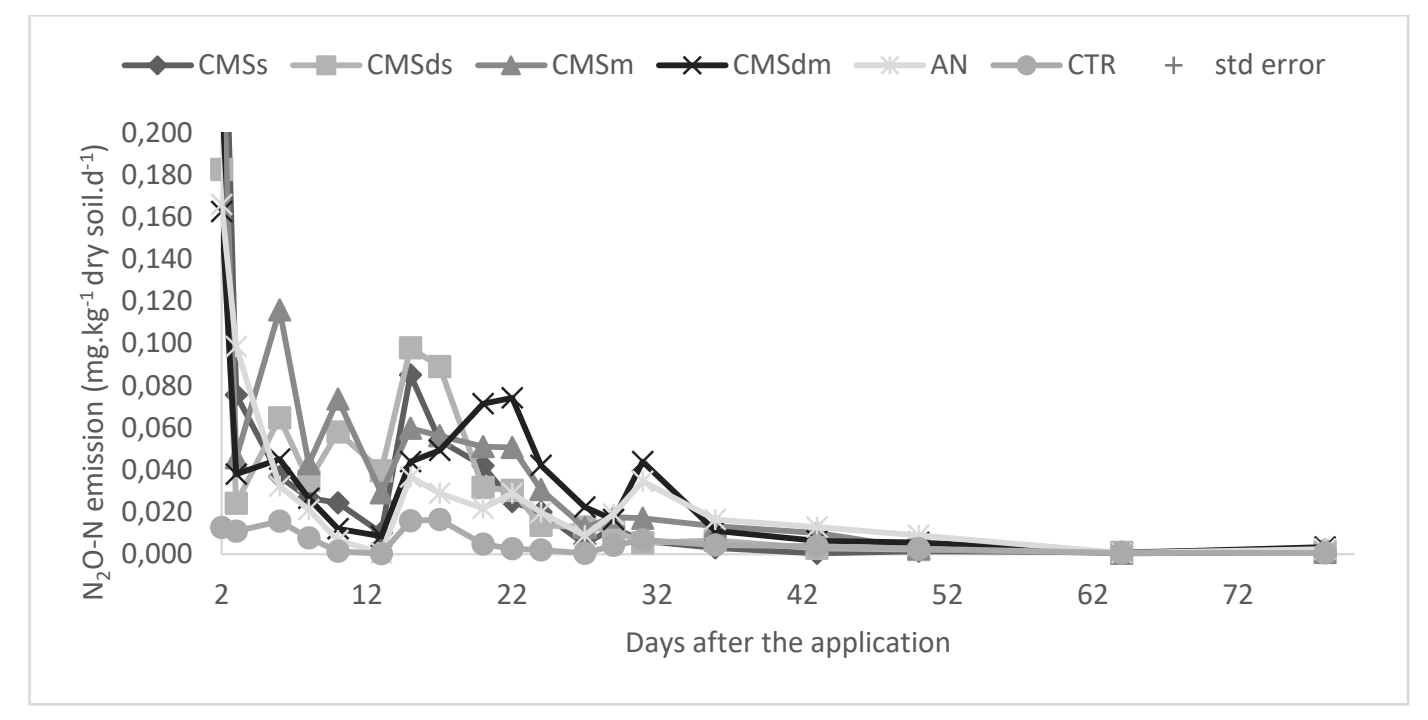

Figure A22- $\mathrm{N}_{2} \mathrm{O}-\mathrm{N}$ emissions evolution during the long-term experiment (78-day period). Means of 3 replicates.

Overall, a higher cumulative emissions was found in yeast treatments. Differences between types of yeast were around 850 and $1133 \mathrm{ug} \mathrm{N} \mathrm{N}_{2} \mathrm{O}-\mathrm{N}^{-\mathrm{kg}^{-1}}$ dry soil in surface and incorporation application. It can also be observed that the mineral nitrogen applied with $\mathrm{AN}$, led to lower $\mathrm{N}_{2} \mathrm{O}$ emissions than CMS and CMSd application.

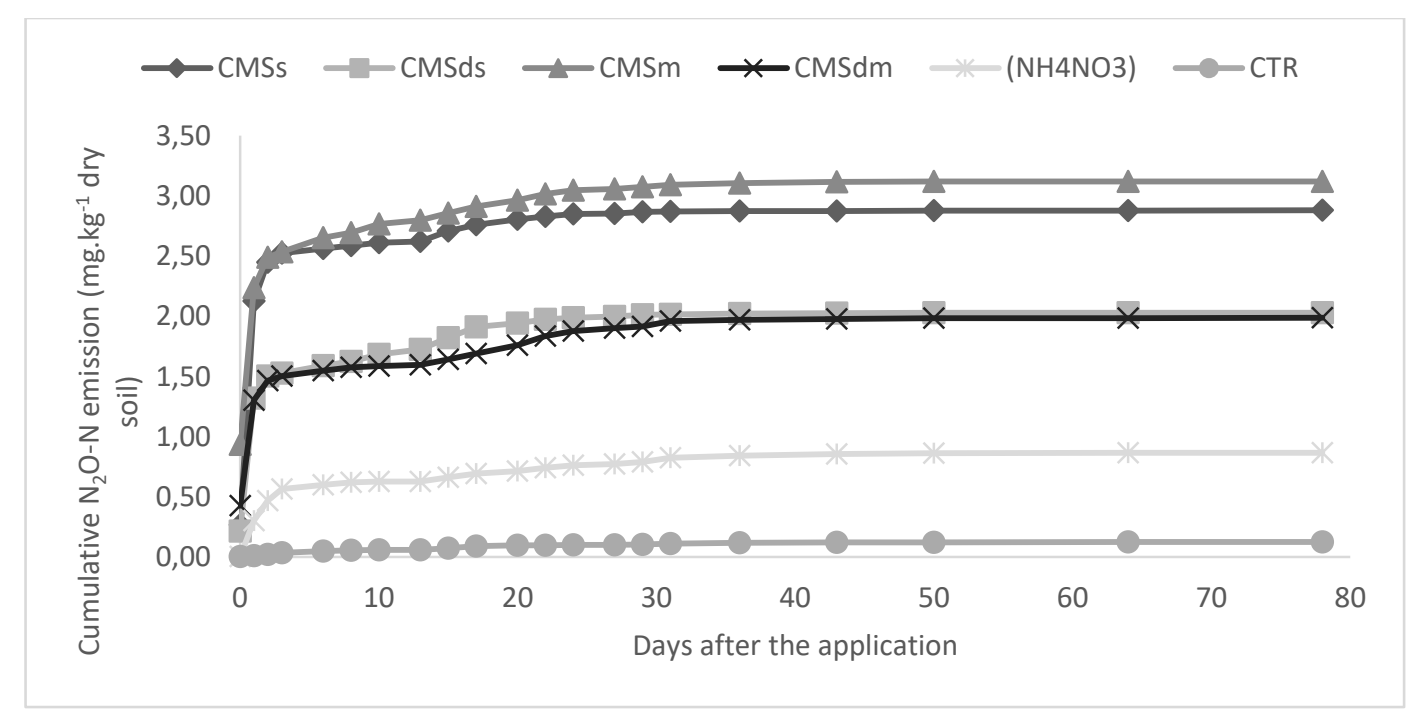

Figure A23 - Cumulative $\mathrm{N}_{2} \mathrm{O}-\mathrm{N}$ emissions during the long-term experiment (78-day period). 
$\mathrm{CO}_{2}$ emissions

On day zero a higher emissions of was observed in yeast treatments compared to other treatments (Figure 34 and 35). A significant increase of $\mathrm{CO}_{2}$ emissions was observed on days 1 and 2 where between 52 and $64 \%$ of total. There were periods when the amount of $\mathrm{CO}_{2}$ emitted in yeast treatments were significantly different from control and AN treatments $(0-2$ and $10-15$ days $)(p<0.01)$. The emissions of $\mathrm{CO}_{2}$ following $\mathrm{AN}$ application were very low. From day 24 onwards, values in all treatments were very similar ( $p>0.05)$ and closer to zero.

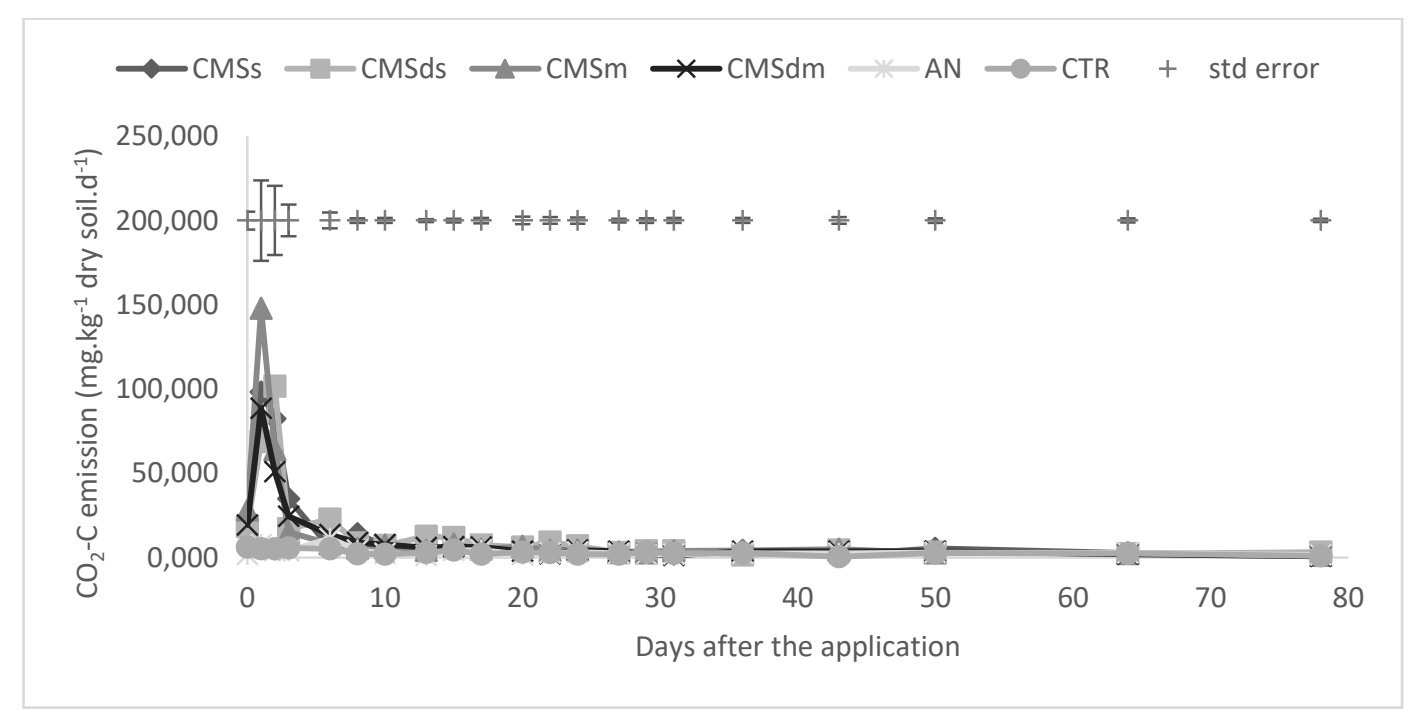

Figure $\mathrm{A} 24-\mathrm{CO}_{2}-\mathrm{C}$ emissions evolution during the long-term experiment (78-day period). Means of 3 replicates. Error bars represent the standard error used on each leaching event to assess significant $(P<0.05)$ differences between mean values.

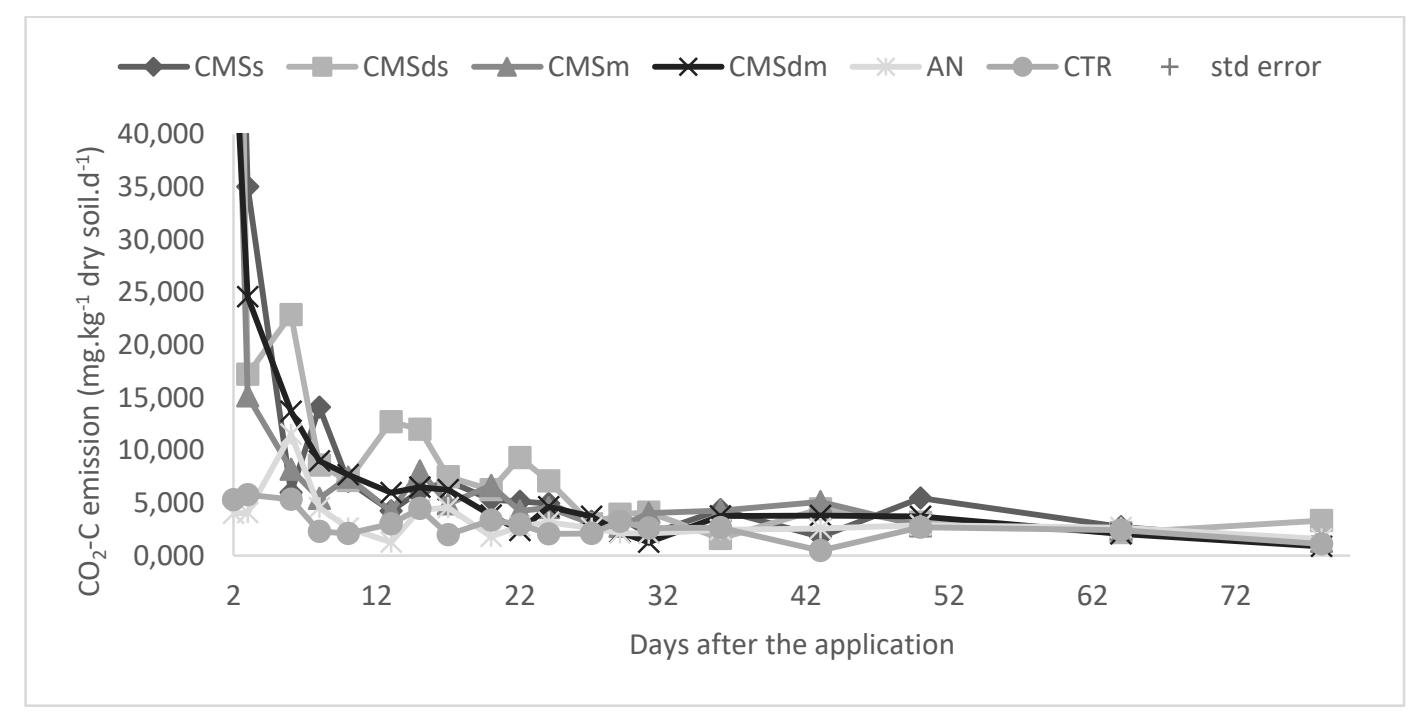

Figure $\mathrm{A} 25-\mathrm{CO}_{2}-\mathrm{C}$ emissions evolution during the long-term experiment (78-day period). Means of 3 replicates. 
CMSdm treatment compared to others CMS treatments, had lower cumulative $\mathrm{CO}_{2}$ emissions (more 197 mg. $\mathrm{kg}^{-1}$ dry soil than control) (Figure 36). AN application provided results very similar to control.

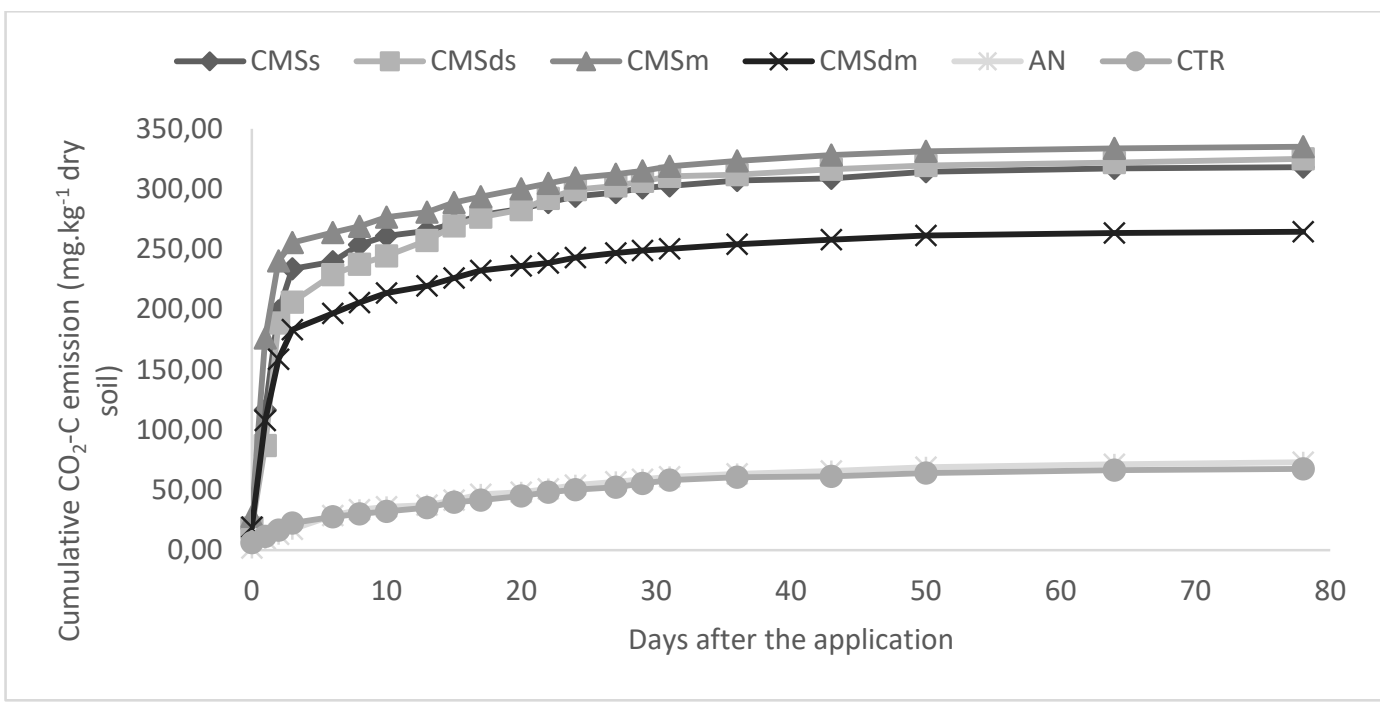

Figure A26 - Cumulative $\mathrm{CO}_{2}-\mathrm{C}$ emissions during the long-term experiment (78-day period). 


\section{$\mathrm{CH}_{4}$ emissions}

During the whole experiment, $\mathrm{CH}_{4}$ emissions wereresidual (Figure 37) even if a small increase was observed on day zero in yeast treatments relative to control.

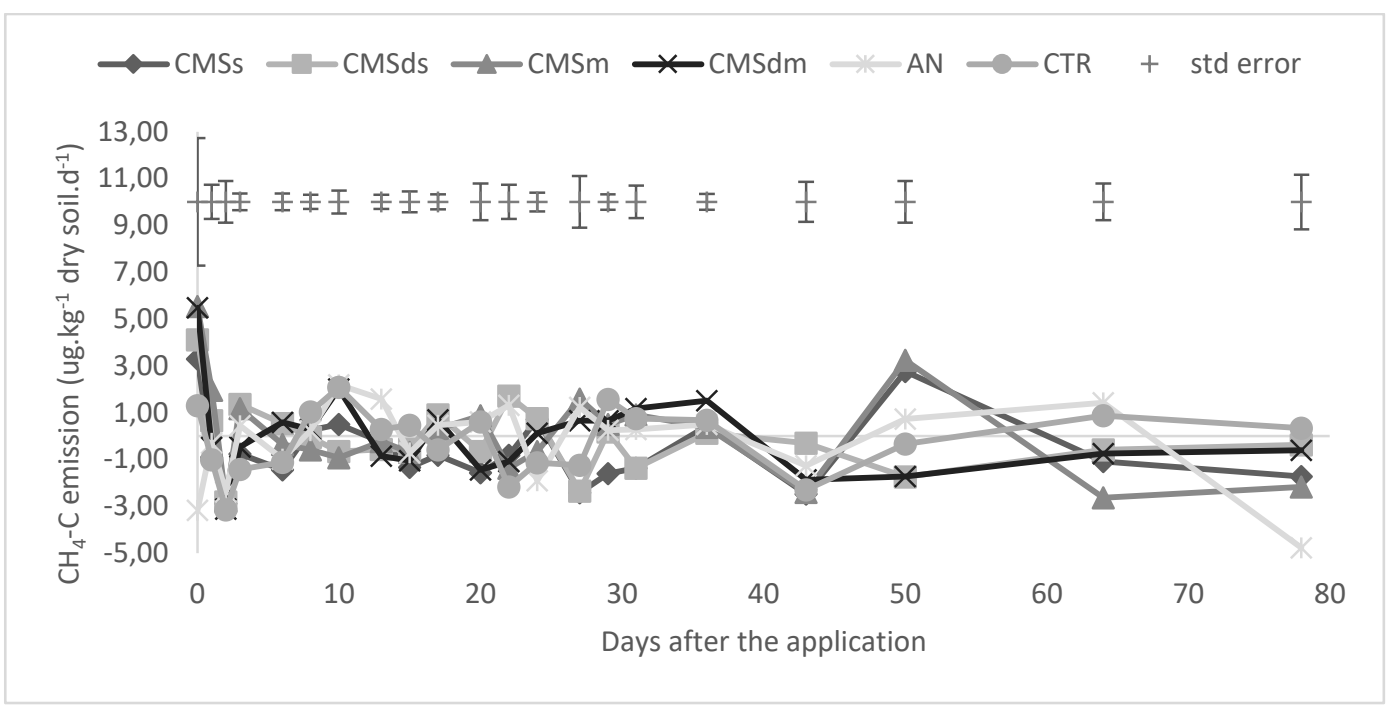

Figure A27 - $\mathrm{CH}_{4}-\mathrm{C}$ emissions evolution during the long-term experiment (78-day period). Means of 3 replicates. Error bars represent the standard error used on each leaching event to assess significant $(P<0.05)$ differences between mean values. 
GWP (global warming potential) based on a 100-year time frame

Results showed in figure 38 indicated that yeast application is clearly worse than AN application for global warming with total values between 1.79 and $2.59 \mathrm{~g} \mathrm{CO}_{2}$ equivalent compared to 0.47 in AN treatments. $\mathrm{N}_{2} \mathrm{O}$ were responsible for around 42.8 and $64.5 \%$ of GWP. $\mathrm{CH}_{4}$ emissions decreased GWP in all treatments except CMSm.

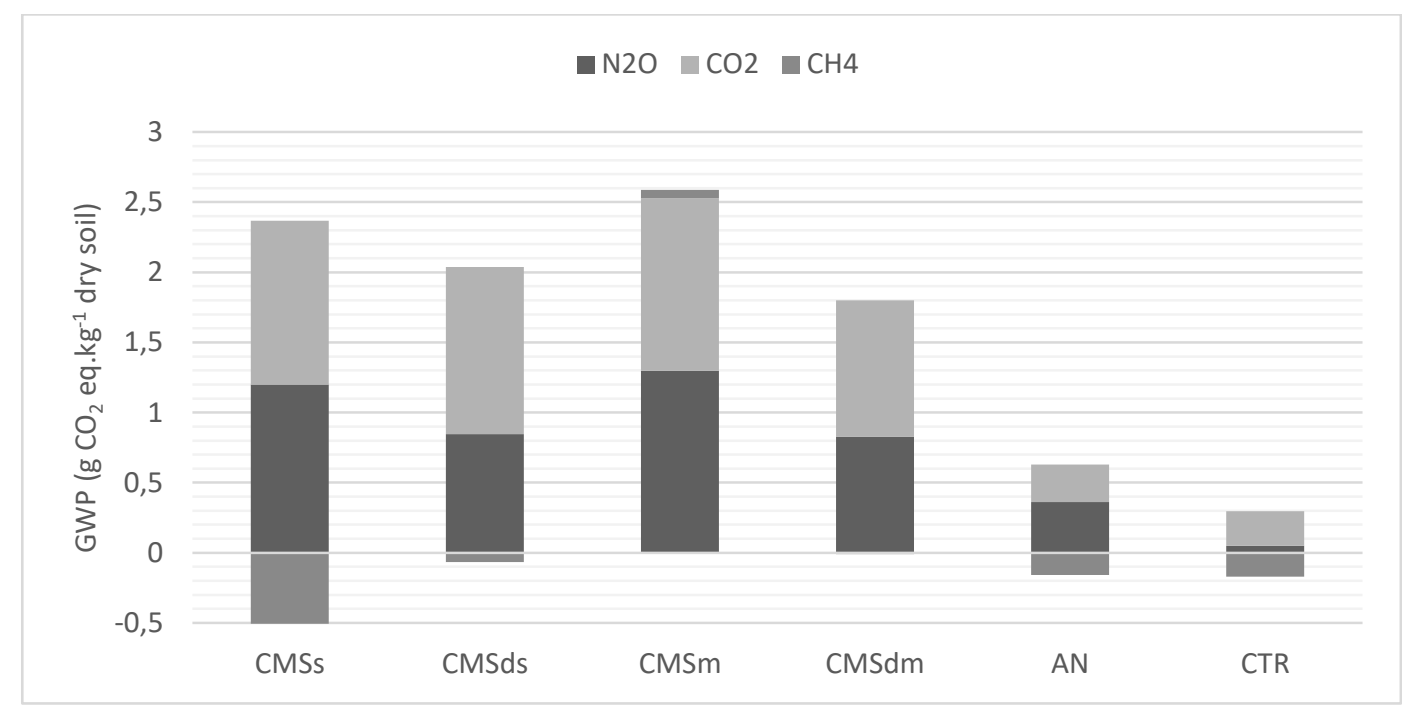

Figure A28 - Global Warming Potential based on a 100-year time frame of GHG emissions during incubation experiment (78-day period). 


\section{Discussion}

\section{D.1. Short-term experiment}

The increase of ammonium leached with yeast application was probably due the mineralization of organic nitrogen and its conversion into ammonium. Indeed, ammonium concentration applied by CMSm and CMSdm were 32 and $43 \%$ of total ammonium losses, suggesting an early and higher mineralization rate. According to Ruijter et al., (2010), application of waste followed by soil incorporation increases ammonium content in soil by reduction of ammonia $\left(\mathrm{NH}_{3}\right)$ volatilization, leading to a higher potential leaching. Also, the surface application in wet soils, particularly with sandy textured soils, exposed to a warming temperatures favours $\mathrm{NH}_{3}$ losses. In general, ammonium losses were not to significant due to its attraction and retention by soil particles on cation exchange complexes (Fangueiro et al., 2014), thereafter its rapid conversion into nitrate. Furthermore, yeast waste increased leachates $\mathrm{pH}$ to optimum values for the nitrification process (6.5 to 8) but there was no evidence of it. On the contrary, as the nitrate is highly mobile in soils and the yeast application decreased nitrate leached relative to control, it suggests a potential rapid denitrification and conversion of nitrate into nitrogen gas forms probably due high nitrate content in soil sample and an intensive irrigation. Soil columns were saturated before and after each IE, providing great conditions for denitrification due to very low oxygen levels and consequently emission of $\mathrm{N}_{2} \mathrm{O}$ (Brady and Weil, 2002). There is, to our knowledge, no previous study about phosphorus and potassium leaching in soils after yeast waste application. However, it is to believe that all phosphorus applied was leached and none adsorbed, particularly due to the sandy texture of soil. Yeast increased the $\mathrm{pH}$ of leachates to neutral levels and also the soil $\mathrm{pH}$, leading to an optimum levels for the maximum plant available $P$ therefore its leaching. According to some studies (Sparks, 2001; Kolahchi and Jalali, 2007), $\mathrm{K}^{+}$losses depend on Calcium ion $\left(\mathrm{Ca}^{2+}\right)$ concentrations that is known to be tightly bound with clay particles at high $\mathrm{pH}$ levels. Soils with poor clay content decrease fixed potassium concentrations therefore increase its potential leaching and availability to plants. CMSd not only led to higher $\mathrm{K}^{+}$losses but also increased significantly $\mathrm{K}$ retained in soil columns, suggesting a potential potassium retention. The increase of EC is easily explained since yeast waste has significant quantity of salts $\left(25.50 / 27.60{\mathrm{mS} . \mathrm{cm}^{-1}}^{-1}\right.$, particularly sodium and potassium. Soil $\mathrm{pH}$ values raised with yeast application to values similar to yeast waste (6.24 and 6.58, CMS and CMSd respectively). According to McKenzie (2003), the availability of micronutrients, such as manganese $(\mathrm{Mn})$, iron $(\mathrm{Fe})$, copper $(\mathrm{Cu})$, zinc $(\mathrm{Zn})$ and boron $(\mathrm{B})$ tend to decrease as soil $\mathrm{pH}$ increases. 


\section{D.2. Long-term experiment}

\section{D.2.1. Potential leaching}

Initial ammonium losses after yeast application suggested an increase of the organic nitrogen mineralization. The higher losses in decanted CMS treatments may be due to the higher mineralization rate but probably also to the increase of ammonia $\left(\mathrm{NH}_{3}\right)$ losses after the application of yeast without incorporation in soil (Ruijter et al., 2010). In general, total ammonium losses were not significant, explaining its strong attraction and retention by soil particles on cation exchange complexes (Fangueiro et al., 2014), thereafter its rapid conversion into nitrate. An increase of nitrate losses on first irrigation events was also observed in some studies, after the application of wastes in soil columns (Li et al., 1997; Fangueiro et al., 2014) mainly due to its highly mobility in soil. The increase of nitrification process is related with the increase of ammonium content. Indeed, unlike ammonium losses, nitrate leached was not correlated with the type of yeast applied in soil but a good correlation was observed with the type of treatment following soil application (incorporation or not), which values were higher in incorporated treatments. The highest nitrate losses with AN application are mainly due to its initial concentration but there was also some evidence of nitrification of the ammonium applied. Furthermore, the interval between two IEs was probably enough to decrease water content in soil columns in order to reach $60 \%$ of WFPS, the optimum value for nitrification (Brady and Weil, 2002). Total P applied in soil by CMS and CMSd applications were 0.93 and $1.94 \mathrm{mg} P$, suggesting that yeast waste is a weak supplier of $P$. Relative to control, surface yeast application showed some ability to increase $P$ retained in soil, around 1.17 and $1.48 \mathrm{mg}$ of phosphorus, CMSs and CMSds respectively. This may be caused by the absorbing of exchangeable $P$ on the top of soil column or its combination with other elements such iron $(\mathrm{Fe})$ and aluminium (Al) oxides (Sinaj et al., 2002) at low pH levels, turning into water-insoluble phosphorus. Ca ions are knowing for its ability to enhance the amount of phosphate adsorbed in soil (Weng et al., 2012). However, as the decanted CMS provides more Calcium than nondecanted CMS (7.81 mg. $\mathrm{kg}^{-1}$ more), $\mathrm{pH}$ levels were not so high in order to decrease P losses. On the other hand, it is believed that all phosphorus was lost in others treatments due sandy texture of soil (Yang et al., 2008). The increase of EC is easily explained since yeast waste has significant quantity of salts $\left(25.50 / 27.60 \mathrm{mS} . \mathrm{cm}^{-1}\right)$, particularly sodium and potassium. 


\section{D.2.2. Nitrogen mineralization}

Results showed a fast mineralization of the organic nitrogen and its conversion to ammonium (ammonification) with the yeast application on day 3. As the yeast C:N ratio (5.37 and 4.19, CMS and CMSd respectively) is very low due high nitrogen content (mostly organic) and its organic composition is mainly labile, it was expected an increase of microbial activity thereafter a marked mineralization rate and the release of ammonium. Pita et al., (2010) showed that, indeed, the application of yeast waste led to a significantly increase of nitrogen mineralization on first days of incubation. Furthermore, $\mathrm{pH}$ increased significantly to neutrality by decreasing hydrogen ions in soil. After a few days, while the ammonium content decreased, nitrate in soil started to increase until the end, suggesting that the incubation experiment had a favourable environmental, including high concentration of ammonium, for the nitrification. Between days

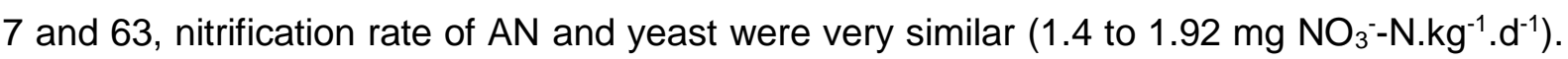
Along the experiment, soil moisture was corrected and its values were remained between 15.6 and $14.6 \%$, corresponding approximately 70.9 and $66.3 \%$ of water-filled pore space. As the correction was every two weeks, it is normal that moisture reached values of $60 \%$ of WFPS, the optimum water content for the nitrification (Brady and Weil, 2002). It was also observed a slight decrease of nitrate on day 3 in yeast treatments due its fast conversion into $\mathrm{N}_{2} \mathrm{O}$ and $\mathrm{N}_{2}$. As expected, the application of AN provided a large initial available of ammonium and nitrate. Compared to yeast treatments, the decrease of ammonium content in soil was slower and there was no evidence of mineralization. Rezende et al., (2004) described that the application of fertilizers provided a poor microbial biomass in soil that led to an insignificant increase of nitrogen mineralized. In general, while surface treatments led to an initial increase of ammonium, incorporation treatments provided more nitrate available in soil with values proximately to AN. 


\section{D.2.3. GHG emissions}

The significant increase of $\mathrm{N}_{2} \mathrm{O}$ on initial days following yeast application can be partially explained by the initial increase of nitrate content in soil (6-8.7 $\mathrm{mg} \mathrm{NO}_{3}-\mathrm{N}$ more than control) followed by its decrease on day 3 as observed in $\mathrm{N}$ mineralization incubation. Furthermore, the amount of readily available carbon provided by yeast led to an increase of denitrification rate (Fangueiro et al., 2008). It is also known that nitrogen gaseous emissions are dependent on the water-filled pore space of soil. The first correction of moisture in soil was $70.9 \%$ of WFPS and according to Butterbach-Bahl et al., (2013), $\mathrm{N}_{2} \mathrm{O}$ emissions are mainly from denitrification at moisture values between 70 and $80 \%$ of WFPS (Bateman and Baggs, 2005). This study demonstrates that incorporation treatments led to an increase of emissions immediately after the application but after that CMS reached higher values than decanted CMS, probably due its higher organic carbon content (4\% more than decanted CMS). Indeed, the higher liquid fraction of CMS may also contribute for nitrous oxide emissions and less emissions of $\mathrm{N}_{2}$ (Fangueiro et al., 2008). On the other hand, the AN application led to a poor increase of $\mathrm{N}_{2} \mathrm{O}$ emissions compared to yeast treatments even if the initial amount of nitrate applied was very high, highlighting the fact that the amount of available carbon applied is a determinant factor for $\mathrm{N}_{2} \mathrm{O}$ emissions.

$\mathrm{CO}_{2}$ emissions are mainly due to fast mineralization of yeast waste that was observed from day 0 to 1 linked to the increase of $\mathrm{N}_{2} \mathrm{O}$, supporting the idea that the carbon applied led to an increase of microbial activity in soil, and its mineralization, thereafter gaseous emissions. Rezende et al., (2004) also reported a high $\mathrm{CO}_{2}$ rates after the application of distillery yeast in soil. According to Pita et al., (2010), a low pH can reduce microbial activity in soil, leading to a decrease of carbon dioxide emissions. Therefore, $\mathrm{CO}_{2}$ emissions were benefited by the significantly increase of $\mathrm{pH}$ to neutrality on first days. Approximately 0.92 and $0.72 \mathrm{~g}$ of total organic carbon were applied in soil with $\mathrm{CMS}$ and decanted $\mathrm{CMS}$. The $\mathrm{CO}_{2}$ emissions observed in CMS and CMSd represented 34.6\% (CMSs) and 45.2\% (CMSd) of the TOC (total organic carbon) applied, suggesting that the organic carbon applied by yeast was not all degradable, contributing for soil organic matter increase.

The insignificant total emission of methane are easily explained by aerobic conditions of the incubation, allowing oxygen circulation in soil and therefore poor or none methanization and/or potential oxidation into $\mathrm{CO}_{2}$ by methanotrophs (Nazaries et al., 2013). 


\section{E. Conclusion}

The dynamic of yeast waste nutrients in soil depends not only on the type of treatment considered but also on soil conditions. For saturated soils and intensive irrigation periods, mix treatment increases greenhouse gases emissions and phosphorus leached. On the other hand, a lower irrigation rate led to a decrease of denitrification rate and therefore a higher nitrate content in soil than surface application treatments. Furthermore, values of nitrate leached on the second irrigation event (long-term leaching experiment) were higher than the maximum allowable value $50 \mathrm{mg} \cdot \mathrm{L}^{-1}$. However, cumulative nitrous oxide emissions were linked to the type of waste in which non-decanted CMS had higher values. Both yeast wastes increased mineralization of organic compounds for plant uptake and $\mathrm{pH}$ soil. The ammonium nitrate application, relative to yeast waste, increased significantly the nitrate leached, and its application, even with small amounts, can easily pollute water courses. On the other hand, its GHG emissions from AN amended soils were very low. In this study a balance between the type of nutrient supplier (yeast waste or ammonium nitrate) and the type of compartment polluted (atmospheric or groundwater) was observed. It is believed that the best application in acidic sandy textured soils, is the surface application of decanted yeast waste, leading to a higher ammonium retention in soil plus lower cumulative nitrous oxide emissions (between yeast wastes) and, on non-intense rainfalls conditions, nitrate losses.

For future researches it could be of interest to investigate the application of yeast waste in soils with different textures or organic matter content to assess the impact of yeast waste application with different soil. As the yeast waste leads to a high mineralization of organic compounds, combining yeast waste with other type of waste such as biochar, which has a higher content of recalcitrant carbon and potential to increase the immobilization of nutrients, could lead to a better sustainable nutrients management, high nitrogen and carbon retention and less GHG emissions. Furthermore it was interesting study its application in high nitrate content soils for remediation, simulating an intensive rainfall and trying to denitrified nitrate ions to $N_{2}$ gas. Energetic sector is another possible destination for yeast waste. The anaerobic digestion and production of biogas for renewable energy production could be a great alternative, decreasing GHG emissions produced by fossil fuels. 


\section{References}

Alvarenga, P., Mourinha, C., Farto, M., Palma, P., Sengo, J., Morais, M.C., Cunha-Queda, C., 2015. Ecotoxicological assessment of the potential impact on soil porewater, surface and groundwater from the use of organic wastes as soil amendments. Ecotoxicology and Environmental Safety, 126, 102-110.

Bateman, E.J., Baggs, E.M., 2005. Contributions of nitrification and denitrification to N2O emissions from soils at different water-filled pore space. Biology and Fertility of Soils, 41, 379388.

Brady, Nyle C., Weil, Ray R., 2002. The nature and properties of soils. $13^{\text {th }}$ Ed.

Butterbach-Bahl K., Baggs, EM., Dannenmann, M., Kiese, R., Zechmeister-Boltenstern, S., 2013. Nitrous oxide emissions from soils: how well do we understand the processes and their controls?. Phil Trans R Soc B. (Ed.).

Diacono, M., Montemurro, F., 2010. Long-term effects of organic amendments on soil fertility. A review. Agronomy for Sustainable Development, 30, 401-422.

Fangueiro, D., Coutinho, J., Cabral, F., Fidalgo, P., Bol, R., Trindade, H., 2012. Nitric oxide and greenhouse gases emissions following the application of different cattle slurry particle size fractions to soil. Atmospheric Environmental, 47, 373-380.

Fangueiro, D., Pereira, J., Chadwick, D., Coutinho, J., Moreira, N., Trindade, H., 2008. Laboratory assessment of the effect of cattle slurry pre-treatment on organic $\mathrm{N}$ degradation after soil application and $\mathrm{N}_{2} \mathrm{O}$ and $\mathrm{N}_{2}$ emissions. Nutrient Cycling Agroecosystems, 80, 107120.

Fangueiro, D., Senbayran, M., Trindade, H., Chadwick, D., 2008. Cattle slurry treatment by screw press separation and chemically enhanced settling: Effect on greenhouse gas emissions after land spreading and grass yield. Bioresource Technology, 99, 7132-7142.

Fangueiro, D., Surgy, S., Napier, V., Menaia, J., Vasconcelos, E., Coutinho, J., 2014. Impact of slurry management strategies on potential leaching of nutrients and pathogens $n$ a sandy soil amended with cattle slurry. Journal of Environmental Management, 146, 198-205.

FAO, 2016. FAOSTAT emissions database, agriculture, agriculture total.

Fortune, S., Lu, J., Addiscott, T.M., Brookes, P.C., 2005. Assessment of phosphorus leaching losses from arable land. Plant and Soil, 269, 99-108. 
Gilbert N., 2012. One-third of our greenhouse gas emissions come from agriculture. Nature News.

Hati, K.M., Biswas, A.K., Bandyopadhyay, K.K., Misra, A.K., 2007. Soil properties and crop yields on a vertisol in India with application of distillery effluent. Soil \& Tillage Research, 92, 60-68.

Horneck, D. \& Miller, 1998. Determination of total nitrogen in plant tissue. In P. Karla (Ed.), Handbook of reference methods for plant analysis, pp. 75-83.

IPCC, 2013. Climate Change 2013: The physical science basis. Contribution of Working Groups I, II, III to the Fourth Fifth Assessment Report of the Intergovernmental Panel on Climate Change [Stocker, T.F., D. Qin, G.-K. Plattner, M. Tignor, S.K. Allen, J. Boschung, A. Nauels, Y. Xia, V. Bex and P.M. Midgley (eds.)]. Cambridge University Press, Cambridge, United Kingdom and New York, NY, USA.

Kolahchi, Z., Jalali, M., 2007. Effect of water quality on the leaching of potassium from sandy soil. Journal of Arid Environments, 68(4), 624-639.

Larchevêque, M., Baldy, V., Montès, N., Fernandez, C., Bonnin, G., Ballini, C., 2006. Shortterm effects of sewage-sludge compost on a degraded Mediterranean soil. Soil Science Society of America Journal, 70, 1178-1188.

Li, Y.C., Stoffella, P.J., Alva, A.K., Calvert, D.V., Graetz, D.A., 1997. Leaching of Nitrate, Ammonium, and Phosphate From Compost Amended Soil Columns. Compost Science \& Utilization, 5(2), 63-67.

McKenzie, R.H., 2003. Soil and Plant Nutrients. Agriculture, Food and Rural Development. Pp. $1-4$.

Nazaries, L., Murrell, J.C., Millard, P., Baggs, L., Singh, B.K., 2013. Methane, microbes and models: fundamental understanding of the soil methane cycle for future predictions. Environmental Microbiology, 15(9), 2395-2417.

Pita V., Vasconcelos E., Fangueiro D., Cabral F., Ribeiro H.M., 2010. Carbon and nitrogen mineralization of organic wastes from sugarcane distilleries: vinasse and yeast waste. Treatment and use of non-conventional organic residues in agriculture, UTL Repository.

Rezende, L.A., Assis, L.C., Nahas, E., 2004. Carbon, nitrogen and phosphorus mineralization in two soils amended with distillery yeast. Bioresource Technology, 94, 159-167. 
Ruijter, F.J.de, Huijsmans, J.F.M., Rutgers, B., 2010. Ammonia volatilization from crop residues and frozen green manure crops. Atmospheric Environmental, 44, 3362-3368.

Sinaj, S., Stamm, C., Toor, G.S., Condron, L.M., Hendrt, T., Di, H.J., Cameron, K.C., Frossard, E., 2002. Phosphorus Exchangeability and Leaching Losses from Two Grassland Soils. Journal of Environmental Quality, 31, 319-330.

Sparks, D.L., 2001. Dynamics of $\mathrm{K}$ in Soils and Their Role in Management of $\mathrm{K}$ Nutrition. Advances in Soil Science: Potassium Dynamics in Soils, 6, 1-63.

Yang, Y., He, Z., Stoffella, P.J., Yang, X., Graetz, D.A., Morris, D., 2008. Leaching behaviour of phosphorus in sandy soils amended with organic material. Soil Science, 173(4), 257-266.

Weng L., Van Riemsdijk, WH., Hiemstra, T., 2012. Factors controlling phosphate interaction with iron oxides. Journal of Environmental Quality, 41(3), 628-635. 